\title{
A Pain Control Optimization Pathway to Reduce Acute Postoperative Pain and Opioid Consumption Postoperatively: An Approach to Battling the Opioid Epidemic
}

\author{
Holly Franson \\ University of St. Augustine for Health Sciences, h.franson@usa.edu \\ DOI: https://doi.org/10.46409/sr.PNGA4970
}

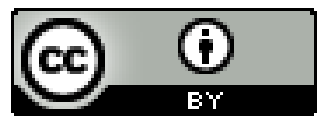

This work is licensed under a Creative Commons Attribution 4.0 License.

Follow this and additional works at: https://soar.usa.edu/scholprojects

Part of the Other Nursing Commons, Perioperative, Operating Room and Surgical Nursing Commons, Public Health and Community Nursing Commons, and the Public Health Education and Promotion Commons

\section{Recommended Citation}

Franson, H. (2020). A Pain Control Optimization Pathway to Reduce Acute Postoperative Pain and Opioid Consumption Postoperatively: An Approach to Battling the Opioid Epidemic. [Doctoral project, University of St Augustine for Health Sciences]. SOAR @ USA: Student Scholarly Projects Collection. https://doi.org/ $10.46409 /$ sr.PNGA4970

This Scholarly Project is brought to you for free and open access by the Student Research at SOAR @ USA. It has been accepted for inclusion in Student Scholarly Projects by an authorized administrator of SOAR @ USA. For more information, please contact soar@usa.edu, erobinson@usa.edu. 
A Pain Control Optimization Pathway to Reduce Acute Postoperative Pain and Opioid Consumption Postoperatively: An Approach to Battling the Opioid Epidemic

Holly E. Franson, CRNA MSN

School of Nursing, University of St. Augustine for Health Sciences

This Manuscript Partially Fulfills the Requirements for the

Doctor of Nursing Practice Program and is Approved by:

Sarah Cartwright, DNP, MSN-PH, RN-BC, CAPA

Anne Hranchook, DNP, CRNA

November 30, 2020 


\section{PAIN CONTROL OPTIMIZATION PATHWAY}

University of St. Augustine for Health Sciences

DNP Scholarly Project

Signature Form

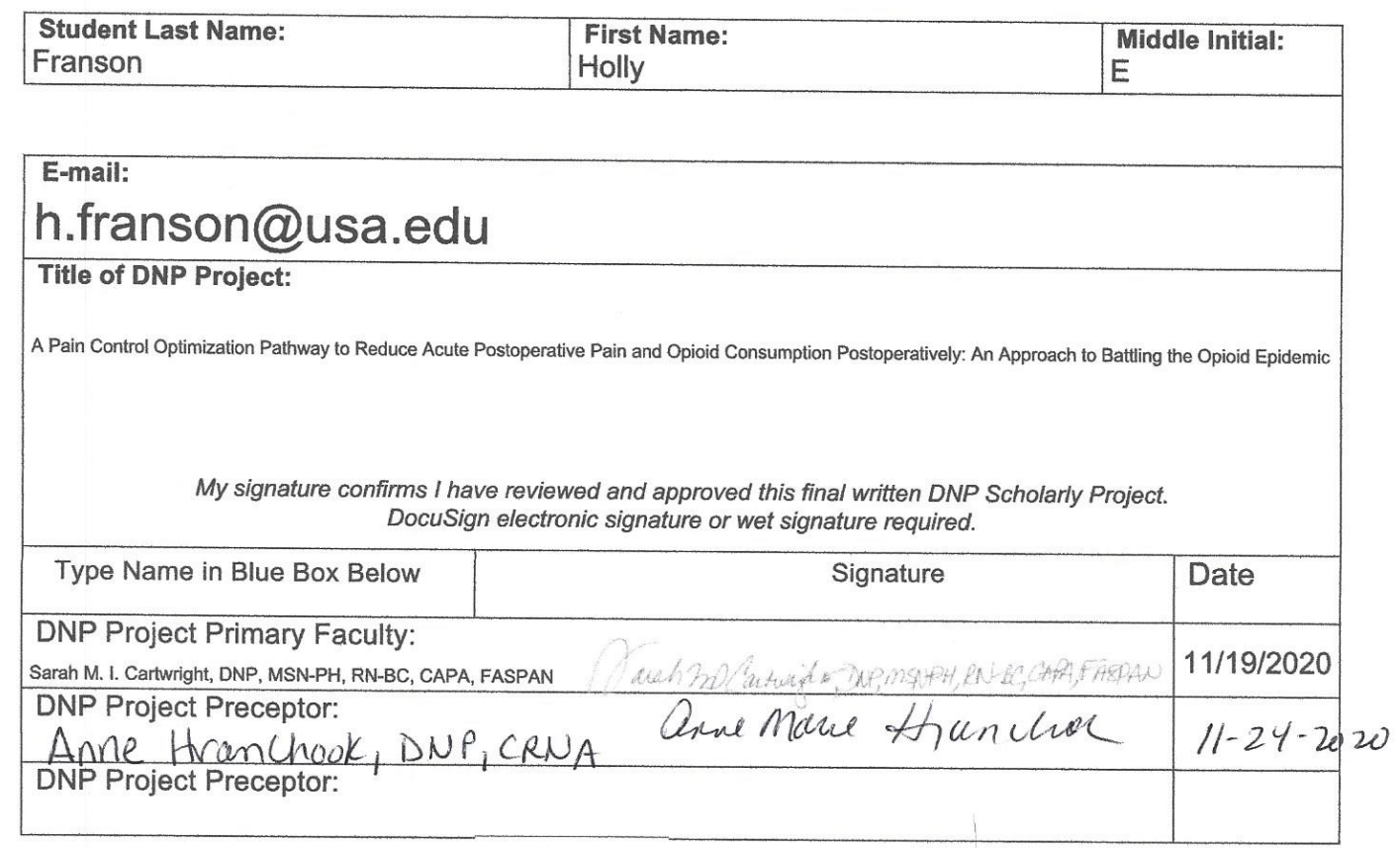




\title{
PAIN CONTROL OPTIMIZATION PATHWAY
}

\begin{abstract}
Practice Problem: Healthcare providers worldwide are working to battle the opioid epidemic and reduce opioid-related harm to patients. Utilizing evidence-based acute pain management methods to reduce opioid consumption is critical to combat the problem.

PICOT: The PICOT question that guided this project was: In opioid-naïve adult patients undergoing general anesthesia for out-patient, minimally invasive abdominal wall hernia surgery, how does the implementation of an evidence-based, preventative Pain Control Optimization Pathway (POP) using a multimodal, opioid-sparing acute pain management technique and standardized procedure-specific opioid prescribing, compared to standard treatment, affect postoperative pain scores and opioid consumption, upon discharge from the recovery room and 72 hours postoperative?
\end{abstract}

Evidence: Evidence supported utilizing a multimodal, opioid-sparing acute pain management technique, patient counseling, and opioid prescribing guidelines to improve outcomes among opioid-naïve patients undergoing abdominal surgeries.

Intervention: In this pre- and post-intervention evaluation, $\mathrm{N}=28$ patients received the POP care process during the perioperative period.

Outcome: Results showed the mean pain score at discharge from the recovery room decreased from 4.8 to 2.82 on the 10-point Numeric Rating Scale post-intervention $(p<0.001)$. Also, provider compliance with prescribing a procedure-specific opioid prescription increased from $73 \%$ to $100 \%$, thus reducing opioid exposure and access.

Conclusion: This project provided evidence that utilization of the innovative POP care process provided optimal pain control and decreased opioid consumption, consequently reducing the risk of new persistent opioid use. 


\section{A Pain Control Optimization Pathway to Reduce Acute Postoperative Pain and Opioid Consumption Postoperatively: An Approach to Battling the Opioid Epidemic}

The purpose of this DNP scholarly paper is to discuss an evidence-based change project that implemented an innovative Pain Control Optimization Pathway (POP) developed by Michigan Opioid Prescribing Engagement Network (OPEN) for reducing acute postoperative pain and opioid consumption as an effort to fight the opioid epidemic. The opioid epidemic is complex and multifactorial; therefore, managing acute perioperative pain becomes imperative as acute pain experiences are often the gateway for new persistent opioid use (OPEN, 2020). A strong body of scientific evidence supported using opioid-sparing acute pain management techniques, patient counseling, and procedure-specific opioid prescribing guidelines to improve outcomes for opioid-naïve patients undergoing out-patient, minimally invasive abdominal wall hernia surgery. Kotter's 8-Step Change Model guided implementation of the preventative POP care process, which focused on preoperative and postoperative patient education and engagement, functional recovery goals, and opioid prescribing recommendations. Intraoperative anesthesia and postoperative care used a multimodal, opioid-sparing protocol as first-line treatment for acute pain, thus utilizing evidence-based techniques from Enhanced Recovery after Surgery, or ERAS (OPEN, 2020). The intervention provided uncompromising pain management, reduced opioid consumption, and showed patient satisfaction. This interdisciplinary approach to transforming perioperative surgical care has the potential to aid in curbing the opioid epidemic.

\section{Significance of the Practice Problem}

The opioid epidemic is a global problem that is tragically resulting in increased morbidity and mortality. It has evolved from a rise in opioid prescribing to control acute and chronic pain, the prevalence of misuse and diversion, and illicit and prescription opioid overdose-related 


\section{PAIN CONTROL OPTIMIZATION PATHWAY}

deaths (Clark \& Schumacher, 2017). While once described as an epidemic in the United States, the opioid crisis is transitioning to a worldwide phenomenon resulting in disease burden and premature mortality (Degenhardt et al., 2014). Globally, in 2018, it was estimated 35.6 million individuals suffered from an opioid use disorder, and 0.5 million deaths were attributed to drug usage (World Health Organization [WHO], 2018). The United States is often blamed for starting the opioid epidemic and had a death rate reaching over 69,000 in 2019 (Centers for Disease Control and Prevention [CDC], 2019). The state of Michigan is not spared from the tragedy surrounding the opioid epidemic. In 2018, the death rate from overdose was over 2,500 compared to only 115 reported deaths in 1999 (Michigan Department of Health and Human Services [MDHHS], 2020). At the local level, Oakland County has seen a $267 \%$ increase in opioid-related deaths from 2009 to 2015 (Access Oakland, 2017).

While the opioid epidemic is complex, managing acute postoperative pain is a critical component to reduce the risk of long-term opioid use. The problem is cyclical. Healthcare providers have an ethical responsibility to provide safe and high-quality acute postoperative pain management, but there is a link between prescribing opioids for acute pain and long-term use, even in opioid-naïve patients (OPEN, 2020). In the United States, nearly 50 million inpatient and outpatient surgical procedures are performed annually (Gan, 2017; Hah et al., 2017). More than $80 \%$ of patients receive opioids because they are the primary method of acute postoperative pain management (Hah et al., 2017). Unfortunately, up to $10 \%$ of opioid-naïve patients continue filling their opioid prescriptions one year following surgery (OPEN, 2020).

Acute postoperative pain is devastating for the patient, family, healthcare system, and society. Patients with postoperative pain have an increased risk of suffering, morbidity and mortality, emotional complications, and delayed healing (Pogatzki-Zahn et al., 2017; Ramia et 


\section{PAIN CONTROL OPTIMIZATION PATHWAY}

al., 2017). There is an increased risk of negative physiologic effects, such as myocardial supply and demand mismatch, interruption of normal respiratory function, activation of the sympathetic nervous system, reduction in gastric motility, and coagulopathy (Bajwa et al., 2017).

Emotionally, pain may lead to anxiety, depression, sleep disturbances, and even inhibit a patient's ability to return to work and obtain an income (Bajwa et al., 2017). The anticipation of pain is a major source of preoperative anxiety for the patient and family. Additionally, an increasing number of outpatient surgeries are being performed, placing the burden of pain management and opioid weaning on patients and caregivers. Families routinely have questions for providers regarding postoperative pain management and counseling becomes vitally important.

When acute postoperative pain is not managed appropriately, patient and family satisfaction is reduced, which is an important quality metric in healthcare (Ramia et al., 2017). Postoperative pain may prolong hospitalization and increase re-admission rates, which increases costs to the healthcare system. The American Academy of Pain Medicine (2019) estimated that pain costs society 560-635 billion dollars annually. Therefore, combating opioid abuse is a state and federal priority. In 2017, the state of Michigan signed a multi-bill to fight the epidemic, focusing on patient counseling, along with prescribing and dispensing regulations for providers (OPEN, 2020).

Overprescribing of opioids in the postoperative setting increases the risk of long-term use (OPEN, 2020). Seventy-two percent of prescribed opioids for surgery go unused and are readily available for misuse or diversion. Unfortunately, the most frequently prescribed opioids (hydrocodone and oxycodone) are the most common causes of death from overdose (Hah et al., 


\section{PAIN CONTROL OPTIMIZATION PATHWAY}

2017). During 2018, in the state of Michigan, 8.4 million prescriptions for opioids were written, which converts to 85 prescriptions per 100 individuals (MDHHS, 2020).

Postoperative opioid prescribing for opioid-naïve patients requires attention. Literature shows an increased risk of new persistent use in opioid-naïve patients, with the total duration of opioid use being the strongest predictor of misuse, diversion, and overdose (Pino \& Covington, 2019). Enhancing patient outcomes requires tailoring an evidence-based perioperative acute pain management care process to the surgical procedure, patient education, and procedure-specific opioid prescribing to reduce the surplus of opioid pills.

\section{PICOT Question}

The PICOT question that guided this project was: In opioid-naïve adult patients undergoing general anesthesia for out-patient, minimally invasive abdominal wall hernia surgery (P), how does the implementation of an evidence-based, preventative Pain Control Optimization Pathway (POP) using a multimodal, opioid-sparing acute pain management technique and standardized procedure-specific opioid prescribing (I), compared to standard treatment (C), affect postoperative pain opioid consumption $(\mathrm{O})$, upon discharge from the recovery room and 72 hours postoperative $(\mathrm{T})$ ?

The population of interest was opioid-naïve patients undergoing general anesthesia for outpatient, minimally invasive abdominal wall hernia surgery. It was important to define "opioid-naïve patients" because the phrase is inconsistently described in the literature. For this project, patients were opioid-naïve if they had not received opioids within 30 days of surgery (Pino \& Covington, 2019). The outpatient, abdominal wall hernia surgery was for repair of inguinal, umbilical, ventral, or incisional hernias using a minimally invasive technique, including laparoscopy or robotic surgery. 


\section{PAIN CONTROL OPTIMIZATION PATHWAY}

The intervention was implementing an evidence-based, multimodal, and opioid-sparing POP care process that provided optimal acute pain management and reduced the risk of new persistent opioid use among opioid-naïve patients. The care process incorporated key components of standard ERAS pathways. The intervention had three phases: preoperative counseling, operative management, and postoperative counseling (OPEN, 2020). The POP care process guided the utilization of a multimodal, opioid-sparing intraoperative anesthetic that was tailored to meet the demands of the surgical procedure, thus reducing exposure to opioids (OPEN, 2020). Multimodal anesthesia is defined to understand its value during the intraoperative phase of the POP care process. It is a technique that combines two or more adjuncts, such as opioids, non-opioids, local anesthetics, regional anesthesia, and non-pharmacologic techniques (American Association of Nurse Anesthetists [AANA], 2019; Mitra et al., 2018). It is generally described as opioid-sparing, thus reducing the side effects associated with opioid administration such as respiratory depression, postoperative nausea, vomiting, and delayed return of bowel function (Kumar et al., 2017). The use of an opioid-sparing and multimodal pain regimen is highlighted in the clinical practice guidelines supported by the American Pain Society and American Society of Regional Anesthesia and Pain Medicine (Chou et al., 2016).

The POP care process focused on interdisciplinary preoperative and postoperative patient counseling, including (a) safe opioid use, storage, and disposal, (b) non-opioid and nonpharmacologic alternatives, (c) recovery and pain expectations, (d) functional recovery goals, (e) current medications and potential high-risk behaviors, and (f) compliance with Michigan Law for prescribing opioids (OPEN, 2020). The program utilized standard procedure-specific prescribing recommendations that have been defined by Michigan OPEN based on literature, expert opinion, and Collaborative Quality Initiative (CQI) patterns (OPEN, 2020). For major or minor hernia 


\section{PAIN CONTROL OPTIMIZATION PATHWAY}

repair, the recommended dose is $0-10$ oxycodone $5 \mathrm{mg}$ or hydrocodone $5 \mathrm{mg}$, consistent with the literature (Bingener et al., 2015; OPEN, 2020).

The comparison was standard treatment, which manages acute pain with standard opioid and non-opioid analgesics. Treatment is based on provider experience and expertise, patient's hemodynamic status, and level of pain, free from consideration of a POP care process. Evidence supported a standard treatment regimen for opioid-tolerant patients; however, it has shown to be a precursor for long-term opioid use among opioid-naïve patients (Hah et al., 2017; OPEN, 2020).

The outcomes included acute postoperative pain scores, opioid consumption variables, and patient satisfaction with the acute pain management process. The Numerical Rating Scale (NRS) was utilized to assess acute pain. The NRS allows the patient to rate their pain with 0 representing "no pain" and 10 representing the "worst pain imaginable." In literature, the NRS is shown to be valid, reliable, easy to utilize, and simple to audit clinically (Bendinger \& Plunkett, 2016; Ozgur et al., 2018). Opioid consumption variables were described by the project leadership team and included utilization of a standard procedure-specific opioid prescription, opioid consumption, opioid disposal, and overall satisfaction with the pain management technique.

The timing was reasonable for the intervention and considered results in the scientific

literature (Bingener et al., 2015). Pain scores were obtained at discharge from the recovery room and 72 hours postoperatively. Time of discharge showed immediate effectiveness of a multimodal, opioid-sparing anesthetic technique on acute pain. Seventy-two hours was a realistic time for acute pain to begin subsiding after minimally invasive abdominal wall surgery and opioid consumption variables to be evaluated. This allowed appropriate evaluation of the 


\section{PAIN CONTROL OPTIMIZATION PATHWAY}

synergistic effect of a multimodal, opioid-sparing pain management plan and opioid requirements.

\section{Evidence-Based Practice Framework and Change Theory}

The change theory that served as the foundation for the project was Kotter's 8-Step Change Model as it is an appropriate framework to develop and implement deliberate and sustainable change (Applebaum et al., 2012). The first step was to create a sense of urgency by assisting key stakeholders in realizing the need for timely change (Applebaum et al., 2012; Small et al., 2016). Then a powerful guiding coalition was established, including key stakeholders and leadership within the organization. The powerful guiding coalition (project leadership team) created a vision for change to communicate and ensure "buy-in" from all providers involved in the perioperative change project (American Association of Nurse Anesthetists [AANA], 0219, p. 8). Next, the frontline providers were empowered as the project leadership team implemented broad-based actions by identifying and removing potential or actual barriers to developing and implementing the project (AANA, 2019; Small et al., 2016). To continue the process of change, short-term goals were created to fuel and generate momentum during the project, and then energy from quick-wins was used as a foundation to continue change (AANA, 2019). Lastly, the changes were anchored into the organization and team culture through recognition, orientation, and recruiting (Small et al., 2016).

The quality improvement framework that guided the development and implementation of the change project was the Plan-Do-Study-Act (PDSA) model as it is a problem-solving model to improve processes and sustain change (Taylor et al., 2014). This is a formative evaluation process that utilized a stages approach through the scientific process of experimental learning with ongoing testing of changes (Knudsen et al., 2019; Sylvia \& Terhaar, 2018). During the 


\section{PAIN CONTROL OPTIMIZATION PATHWAY}

"planning" phase, the project leadership team was identified, opportunities for improvement acknowledged, and plans were made (Sylvia \& Terhaar, 2018). It was of utmost importance the project leadership team understood the intervention, goals, measurement strategy, and measures of success based on the analysis of organizational processes. During the "do" phase, the project was executed, data collected, and displayed (Sylvia \& Terhaar, 2018). The "study" phase required interprofessional collaboration as the team members worked together to evaluate the intervention outcomes and assess if outcomes were desirable (Sylvia \& Terhaar, 2018). Lastly, during the "act" phase, a decision was made to implement the intervention as the cycle had been completed successfully. The model was well suited to provide a process and communication flow to ensure compliance with the POP care process.

\section{Evidence Search Strategy}

The evidence search strategy was guided by the PICOT process to ensure evidence-based and clinically significant literature was used to guide the project. The EBSCO host interface for the Cumulative Index of Nursing and Allied Health Literature (CINAHL) database, PubMed database, Cochrane Library, and Google Scholar were searched for the PICOT question's major elements with natural language, subject, and medical subject headings (MeSH). In the CINAHL database, the search mode was refined to "Boolean/Phrase" to ensure exact phrase searching. To execute the search, separate advanced searches were performed related to the population, intervention, and outcomes then combined using the search history. Related to the population, keywords included: (a) [(minimally invasive surgery) OR (minimally invasive hernia surgery)],

(b) [(abdominal surgery) OR (abdominal procedure) OR (abdominal operation)], and (c) [(hernia surgery) OR (hernia procedure) OR (hernia operation)]. Keywords for the intervention included: (a) [(enhanced recovery after surgery) OR (ERAS)], (b) [(opioid-sparing) OR (opioid-free)], (c) 


\section{PAIN CONTROL OPTIMIZATION PATHWAY}

[(pain control pathway) OR (pain management pathway)], and (d) multimodal anesthesia.

Outcome search used: (a) [(postoperative pain) OR (acute postoperative pain) OR (acute pain)], (b) [(pain score) OR (pain level)], (c) [(opioid use) OR (opioid consumption)], and (d) [("longterm opioid use") OR ("persistent opioid use")]. The initial search yielded over 14,000 articles, so the search was refined by adding limiters to focus the results, including peer-reviewed, evidence-based practice, randomized controlled trials (RCTs), all adult population, publication date within ten years, and English language. This produced 146 articles. Subject major headings were added, including postoperative pain, analgesics, non-opioids, and opioids. Titles were reviewed for relevance to the PICOT question, followed by a review of abstracts for inclusion and exclusion criteria.

Inclusion criteria included Johns Hopkins evidence-based level one through five and quality grades A through C evidence (Dearholt \& Dang, 2018). Exclusion criteria included: (a) open surgical procedures not on the abdominal wall, (b) primary outcome comparing multimodal techniques, (c) lack of multimodal anesthesia technique utilized, (d) comparing regional techniques, (e) comparing local anesthetics, and (f) population of chronic opioid users. Articles not available in the full-text were requested by inter-library loan. Also, hand searches were conducted using the reference lists of appropriate articles. Fifty-two complete articles were reviewed.

In the PubMed database, an advanced search of the keywords above yielded over 40,000 articles, so a refined search was carried out. These keywords included: (a) ["enhanced recovery after surgery" [MeSH] OR (ERAS) OR "multimodal anesthesia"], (b) [("minimally invasive surgery") OR ("abdominal wall surgery")], (c) [("postoperative pain management") OR ("postoperative pain")], and (d) [("opioid consumption" OR "opioid use")]. Terms were 


\section{PAIN CONTROL OPTIMIZATION PATHWAY}

combined with the connector word "AND." After applying filters published in the last 10 years, humans, English, and adult (nineteen or older), 168 articles were yielded. Titles were reviewed for relevance to the PICOT question, duplicates removed, the similar articles function used, and abstracts were reviewed for inclusion and exclusion criteria. Hand searches of reference lists were conducted and thirteen additional articles were reviewed. To ensure a comprehensive evidence search, the Cochrane Library and Google Scholar were searched using natural language "enhanced recovery after surgery", "enhanced recovery minimally invasive surgery", “multimodal opioid-sparing surgery", and "acute postoperative pain management" resulting in five additional articles. Collectively, 25 full articles were relevant to the PICOT question.

\section{Evidence Search Results and Evaluation}

The search strategy detailed above utilized the EBSCO host interface for the Cumulative Index of Nursing and Allied Health Literature (CINAHL) database, PubMed database, Cochrane Library, and Google Scholar for the major elements of the PICOT question. The search results included 25 research articles presented in a primary research evidence table and a summary of systematic reviews (see Appendix A and Appendix B). Figure 1 is a PRISMA model describing the identification, screening, and eligibility processes.

The Johns Hopkins nursing evidence-based practice level and quality grade model was utilized to determine the strength of evidence (Dang \& Dearholt, 2018). The 25 articles included three meta-analyses and four systematic reviews with level one evidence and a quality grade A (high-quality results). Two randomized control trials (RCTs) had level one evidence and a quality grade A. Also included were nine cohorts and one case-control study with level two to three evidence and a quality grade B (good quality results). Lastly, six literature reviews with level five and quality grade B evidence supported the PICOT question. 


\section{PAIN CONTROL OPTIMIZATION PATHWAY}

\section{Themes}

A thorough evaluation of literature guided by the PICOT question revealed several common themes that revolved around the importance of utilizing a multimodal, opioid-sparing program to control acute postoperative pain and prevent long-term opioid use among opioidnaïve patients. Reoccurring themes included: (a) enhanced recovery after surgery (ERAS) is an evidence-based, multimodal, and opioid-sparing program to improve outcomes for a variety of abdominal surgeries, (b) multimodal, opioid-sparing programs adequately control postoperative pain, reduce postoperative opioid consumption, improve outcomes, and enhance patient satisfaction, (c) procedure-specific standardized prescribing guidelines are associated with reduced postoperative opioid consumption, and (d) preoperative and postoperative patient counseling are beneficial components of opioid-sparing programs.

Compared to standard care, an ERAS program is associated with improved outcomes for abdominal surgery, including decreased length of hospitalization, adequate postoperative pain management, reduced opioid consumption, decreased overall costs, reduced adverse events, and improved quality of life. Of 11 good and high-quality articles, three specifically addressed ERAS for minimally invasive abdominal, gynecology, or urogynecologic surgery and consistently published improved outcomes. The articles reliably showed a reduced length of stay (LOS), decreased pain scores, fewer opioids, reduced adverse events, and decreased costs with ERAS and minimally invasive surgery, or MIS (Chapman et al., 2016; Kalogera et al., 2019; Trowbridge et al., 2019). A retrospective case-control study by Chapman et al. (2016) evidenced ERAS with MIS increased postoperative day one discharge from $60 \%$ to $91 \%$, reduced average costs from $\$ 15,649$ to $\$ 13,771$, and decreased opioid use by $30 \%$. The percentage of patients discharged by noon doubled when ERAS is combined with MIS, thus reducing costs and 


\section{PAIN CONTROL OPTIMIZATION PATHWAY}

improving perioperative productivity (Chapman et al., 2016; Kalogera et al., 2019; Trowbridge et al., 2019). Trowbridge et al. (2019) had similar outcomes reducing the LOS by 2.07 hours, yet only reported a slight reduction in mean pain scores, 4.49 versus 4.26 out of 10 . Nonetheless, total morphine equivalents were significantly reduced and patient satisfaction statistically higher (Trowbridge et al., 2019).

Five studies had similar positive outcomes with ERAS and open procedures on the abdomen related to LOS, costs, improved functional recovery, and adverse events (Harryman, 2019; Li et al., 2019; Majumder et al., 2016; Smith et al., 2016; Wijk et al., 2019). Length of stay reduced by $50 \%$ with lowered overall costs of hospitalization (Li et al., 2019; Majumder et al., 2016). Enhanced recovery after surgery improved physical functioning, health-related quality of life, and fatigue scores in multiple studies, along with reducing adverse events (Li et al., 2019; Wijk et al., 2019). On the contrary, one RCT revealed no statistical difference with open surgery and MIS of the abdomen related to fatigue, physical and mental health. Still, the authors noted significantly reduced LOS and no difference in complications (Kennedy et al., 2014). Overall, evidence emphasized MIS has a statistically significant synergistic effect with ERAS related to LOS, costs, opioid use, and adverse events (Chapman et al., 2016; Harryman, 2019; Kalogera et al., Li et al., 2019; Majumder, 2016; Smith et al., 2016; Spanjersberg et al., 2015; Trowbridge et al., 2019; Wijk et al., 2019; Zhao et al., 2016.

A multimodal, opioid-sparing perioperative pathway, when compared to standard care, is associated with reduced postoperative pain scores, decreased opioid consumption, enhanced patient satisfaction, and improved patient-reported outcomes (PROs). Of seven articles, one meta-analysis provided evidence that multimodal analgesia with regional anesthesia significantly reduced pain scores $(p<0.001)$ and improved patient satisfaction (Zhou et al., 2017). Opioid use 


\section{PAIN CONTROL OPTIMIZATION PATHWAY}

decreased by $72 \%$ with an opioid-sparing pathway and opioid-naïve patients experienced positive outcomes with high satisfaction (Hallway et al., Meyer et al., 2018; 2019; Zhou et al., 2017). Specifically, evidence showed an opioid-sparing pathway reduced median postoperative opioid use to ten pills or less (average of four pills) in 98\% of patients (Hallway et al., 2019). Opioid-sparing techniques may also result in no postoperative opioid use when patients utilize a combination of acetaminophen and ibuprofen (Hallway et al., 2019). One narrative review found multimodal techniques significantly improved postoperative pain scores but specifically showed opioid-free analgesia had the highest patient and surgeon satisfaction (Nassif \& Miller, 2018). Echeverria-Villalobos et al. (2019) evidenced opioid-sparing analgesia had optimal analgesia, improved patient safety, and fewer adverse events. Also, the authors linked short-term exposure to long-term use (Echeverria-Villalobos et al., 2019). This was similar to two narrative reviews discussing the negative effects of long-term opioid use after surgery among opioid-naïve patients (Hah et al., 2017; Kumar et al., 2017). Surgical patients present a challenge to balancing pain management and limiting opioid use; therefore, multimodal, opioid-sparing pathways are advocated in literature and proven effective in reducing postoperative opioid consumption.

Six articles discussed procedure-specific standardized prescribing guidelines are associated with reduced postoperative opioid consumption among surgical patients. Two systematic reviews reported patients had unused opioids, low pain scores, and poor knowledge or plan for proper opioid disposal (Bickett et al., 2017; Feinberg et al., 2018). Opioid oversupply is reported as high as $67 \%$ to $92 \%$ with low anticipated or actual proper disposal (Bickett et al., 2017). Feinberg et al. (2018) reported a lack of education and awareness among patients regarding proper disposal and advocated for education among providers to transition to procedure-specific and standardized prescribing. One retrospective cohort study reported an 


\section{PAIN CONTROL OPTIMIZATION PATHWAY}

ERAS program increased the utilization of opioid-free anesthesia from $17 \%$ to $58 \%$ (Brandal et al., 2017). On the contrary, opioid prescriptions at discharge did not decrease significantly (85\% to $78 \%$ ), thus showing the need for education on prescribing practices (Brandal et al., 2017). Provider training on evidence-based best practices for pain management and standardizing prescribing guidelines have significantly reduced the number of opioid pills and oral morphine equivalents prescribed after outpatient surgery (Stepan et al., 2019).

Provider education and knowledge regarding procedure-specific prescribing and multimodal, opioid-sparing techniques are important in reducing postoperative opioid use. However, patients must be appropriately counseled (Kalogera \& Dowdy, 2019; Soffin et al., 2017). Key components of preoperative and postoperative patient counseling include addressing the risk of opioid therapy, the danger of sharing opioids, the risk of long-term use, safe disposal methods, and expectations of pain management (Kalogera \& Dowdy, 2019; Soffin et al., 2017). Counseling regarding the advantages of preemptive analgesia, utilizing multiple components of the ERAS program, and regional anesthesia are valuable in setting patient expectations regarding the acute pain management program.

This literature synthesis is good to high quality and directly related to the components of the PICOT question. Evidence supported implementing an evidence-based, opioid-sparing POP care process for managing acute postoperative pain after minimally invasive, abdominal wall hernia surgery on opioid-naïve patients. The intervention, outcomes, and key findings support the program's success in controlling acute postoperative pain, reducing postoperative opioid consumption, and improving patient-reported outcomes. 


\section{PAIN CONTROL OPTIMIZATION PATHWAY}

\section{Practice Recommendations}

A rigorous review of literature has validated implementing a program encompassing an evidence-based, multimodal, and opioid-sparing acute pain management technique and standardized opioid prescribing for opioid-naïve patients undergoing out-patient, minimally invasive abdominal wall hernia surgery. The intervention has proven to reduce pain scores, decrease opioid consumption, enhance patient satisfaction, improve PROs, reduce LOS, and decrease costs (Chapman et al., 2016; Kalogera et al., 2019; Trowbridge et al., 2019). Utilization of a standardized care process encompassing evidence-based aspects of ERAS such as a multimodal, opioid-sparing perioperative course for first-line treatment, preoperative and postoperative patient counseling regarding an opioid-sparing perioperative course, and procedure-specific postoperative opioid prescribing guidelines are recommended to improve patient outcomes based on good and high-quality evidence (see Appendix A and Appendix B). Although no study specifically addresses the POP care process, it is an evidence-based program developed by Michigan OPEN. The program addresses patient counseling, best practices, and provider education, all interventions are supported in the literature (OPEN, 2020). Michigan OPEN is supported and affiliated with the Michigan Department of Health and Human Services, Institute for Healthcare Policy and Innovation, and Blue Cross Blue Shield of Michigan to combat the opioid epidemic (OPEN, 2020). Figure 2 provides an overview of the recommended POP perioperative care process. The project leadership team recognized there were no data collection tools specifically designed for the Michigan OPEN POP care process yet created a tool that may serve as a foundation for future projects.

Utilization of the POP care process for minimally invasive abdominal wall surgery addressed the practice problem of reducing acute postoperative pain and opioid consumption 


\section{PAIN CONTROL OPTIMIZATION PATHWAY}

among opioid-naïve patients to reduce the risk of long-term use and associated side effects. It introduced the perioperative team to an evidence-based strategy that standardized an innovative, opioid-sparing acute pain management plan, tailored to the surgical procedure. The program also highlighted central concepts in the postoperative pain management clinical practice guidelines, which emphasized the importance of preoperative education, perioperative pain management planning, use of multimodal therapies, peripheral regional anesthesia, and organizational structure and policy (Chou et al., 2016).

Michigan OPEN POP recommendations (unless contraindicated) includes the preoperative use of acetaminophen one gram by mouth, intraoperative use of local anesthetics, ketorolac 30 milligrams intravenously at closing, or postoperative ketorolac 30 milligrams intravenously if not administered intraoperatively (OPEN, 2020). Preoperative counseling occurs at the surgical or preoperative consult. The patient receives education regarding pain expectations and norms, schedule for non-opioid medication plan, alternative pain management modalities, appropriate use of opioids, adverse effects, and safe disposal (OPEN, 2020). Also, the intraoperative and postoperative acute pain management plan is addressed (OPEN, 2020). Postoperative counseling includes written communication of a consistent message regarding functional pain management goals and non-opioid adjuncts (OPEN, 2020). The over-the-counter medication regimen at discharge is acetaminophen 650 milligrams every six hours, alternating with ibuprofen 600 milligrams every six hours by mouth (OPEN, 2020). Standardized procedurespecific prescribing of opioids for abdominal wall hernia repair is zero to ten pills and left to provider discretion (OPEN, 2020). Patients are notified opioids are utilized for only breakthrough pain during the first 24 to 48 hours (OPEN, 2020). 


\section{PAIN CONTROL OPTIMIZATION PATHWAY}

Based on scientific evidence, it was recommended to implement the preventative POP care process described by Michigan OPEN into the perioperative protocol at the organization for opioid-naïve patients undergoing minimally invasive, out-patient abdominal wall hernia surgery. The POP program is based on best practices adopted from ERAS programs supporting an evidence-based, multimodal, opioid-sparing acute pain management program, preoperative and postoperative patient counseling, and standardized procedure-specific opioid prescribing. It was anticipated to reduce acute postoperative pain scores, decrease opioid consumption, and enhance patient satisfaction at discharge and after 72 hours.

\section{Project Setting}

The project setting was Michigan's largest health care system, with eight hospitals, 145 outpatient locations, and over 38,000 employees (Beaumont, 2020). It is a not-for-profit and teaching organization, Magnet Recognized, and affiliated with three local medical schools and graduate medical education (Beaumont, 2020). The organization's mission is to provide compassionate and extraordinary care based on a foundation of safety, patient and familycenteredness, and transparency regarding the quality of care and success (Beaumont, 2020). The vision is to be a leader in delivering high-value care through compassion, innovation, and education (Beaumont, 2020). The culture embraces a caring partnership, community outreach, and care delivery model of patient and family-centered care. The organization is a newly merged health system and the organizational structure includes a President \& Chief Executive Officer and Board Chair who oversee the health board, executive team, and senior leadership (Beaumont, 2020).

A combination of best practice in literature, legislation, and a desire to combat the opioid epidemic established the organizational desire to implement an acute postoperative pain 


\section{PAIN CONTROL OPTIMIZATION PATHWAY}

management program for opioid-naïve patients undergoing minimally invasive hernia surgery (C. Schmidt, personal communication, March 6, 2020). There is strong evidence a standardized program encompassing evidence-based aspects of ERAS, preoperative and postoperative patient counseling regarding an opioid-sparing perioperative course, and procedure-specific opioid prescribing results in improved patient outcomes. Also, in 2017 the state of Michigan signed a multi-bill package to combat the opioid epidemic (OPEN, 2020). Lastly, there are financial incentives to using the POP program as surgeons may report modifier 22 for an additional $35 \%$ reimbursement (OPEN, 2020).

Organizational support was confirmed by personal communication with the Director of Anesthesia Services, anesthesiologists, and general surgeons. Collectively, the perioperative providers desired an intervention considering best practices to combat the opioid epidemic. The Checklist to Assess Readiness for Implementation (CARI) was utilized to assess the healthcare organization's capacity to support the change project and ensure success (Barwick, 2011). The organization showed the highest scores related to staff desire and readiness for practice change, leadership acknowledging the importance of the problem and value in the intervention, and the organizational mission supporting innovative and evidence-based practice (Barwick, 2011). The plan for stability is multifactorial, beginning with aligning the project short- and long-term goals with the organizational goals. Also, continuously engaging key stakeholders through effective communication via multiple channels and providing on-going education to the perioperative providers regarding the intervention and outcomes.

Stakeholders include anesthesiologists, certified registered nurse anesthetists (CRNAs), Director of Anesthesia Services, surgeons, surgery office staff, preoperative care unit nurses, post-anesthesia care unit (PACU) nurses, quality and patient safety department, billing and 


\section{PAIN CONTROL OPTIMIZATION PATHWAY}

coding departments, and the patient. Interprofessional collaboration among stakeholders was maintained by considering Interprofessional Education Collaborative (IPEC) core competencies, including creating a climate of shared values and respect, role identification, accountability, and transparency (IPEC, 2016). These competencies were integrated and applied to the quality improvement framework and change theory guiding the project, along with continuous communication and feedback driving the processes.

A SWOT analysis was performed related to the current state of the organization (See Figure 3 for the SWOT analysis for this project). Strengths included support from leadership, teamwork capability, the volume of cases, and experience of providers. Weaknesses were a lack of protocols for acute postoperative pain management and lack of provider training regarding standardized procedure-specific opioid prescribing. Opportunities were strong scientific evidence, key stakeholders' motivation to implement the POP pathway, improvement in acute postoperative pain scores, improved PROs, decreased LOS, and reduced postoperative opioid use. Threats were organizational production pressure, time constraints, costs, and resistance to change.

\section{Project Overview}

This project's mission was to implement and sustain an evidence-based acute perioperative pain management program for opioid-naïve patients undergoing out-patient, minimally invasive abdominal wall hernia surgery to reduce pain and decrease opioid use. The vision was to advocate for the patient and center the intervention around providing respectful, patient-centered, and high-quality acute pain management. This is congruent with the organization's mission and vision focusing on leading innovative care, safety, and patientcenteredness. 


\section{PAIN CONTROL OPTIMIZATION PATHWAY}

Multiple short-term objectives were identified to implement the POP care process for managing acute postoperative pain. First, $95 \%$ perioperative provider compliance with utilizing an opioid-sparing, multimodal technique as the first-line treatment for acute pain management. Ninety-five percent perioperative provider compliance with preoperative and postoperative patient counseling. Ninety-five percent compliance with the utilization of standardized procedure-specific opioid prescribing. Average patient pain score at discharge from PACU with opioid-sparing, multimodal technique less than four on a 10-point VRS and less than two after 72 hours. Average patient postoperative opioid use at or below the prescribed number of pills after 72 hours.

The long-term objectives were to ensure compliance with on-going provider education, maintain interprofessional communication, and sustain the program. The goal was to avoid risk and unintended consequences during the project; however, there is potential for provider resistance to changing opioid practices, increased costs related to educating providers, and increased time related to patient preoperative and postoperative counseling.

\section{Project Plan}

The change model that guided this evidence-based change project was Kotter's 8-Step Change Model as it is appropriate to create a culture for change, engage and empower providers, develop and implement the intervention, and sustain the change with continuous quality improvement (Applebaum et al., 2012; Small et al., 2016). The implementation plan involved the collaboration of an interprofessional project leadership team, including the project manager (DNP student), key stakeholders, and project champions. It was of utmost importance the leadership team exhibited transformational leadership skills and focused on changing the status quo through communicating a vision and fostering inspiration within the group (Longest \& Daar, 


\section{PAIN CONTROL OPTIMIZATION PATHWAY}

2008). As this intervention involved multiple phases of the perioperative process, the project was divided into smaller elements with a strategic communication plan to ensure coordination of care. The interprofessional leadership team communicated face-to-face monthly and via email weekly, or as appropriate. The project champions maintained communication between the project leadership team and perioperative providers as appropriate. The project manager oversaw the entire process. Table 1 shows each team member's responsibility.

The intervention was a POP care process based on best practices during three perioperative phases, including (a) preoperative counseling, (b) operative management, and (c) postoperative counseling (see Figure 2). The interprofessional project leadership team collaborated to develop provider educational materials and resources based on high-quality evidence, systemic reviews, and practice guidelines to successfully implement the intervention. Provider education and resources included best practices for the pain control optimization pathway, prescribing recommendations, and patient counseling materials (see Appendix C).

\section{Create a Sense of Urgency}

Establishing a sense of urgency involved guiding others to see the need for immediate change (Applebaum et al., 2012; Mindtools, 2020; Small et al., 2016). The Director of Anesthesia Services and DNP student recognized the need for implementing an acute postoperative pain management pathway to control pain and reduce opioid consumption during the perioperative period. Consideration of the risks surrounding opioid use motivated practice change. Also, the practice problem's significance was viewed as an opportunity to improve patient outcomes and satisfaction. A sense of urgency was conveyed to key stakeholders during a face-to-face meeting with consideration of best practices in scientific literature, desire to improve patient outcomes, and recent legislation in Michigan to reduce opioid consumption. The 


\section{PAIN CONTROL OPTIMIZATION PATHWAY}

momentum to move forward with the intervention was immediately established among key stakeholders. To transition this sense of urgency to perioperative providers, the leadership team developed a brief verbal and nonverbal overview of the project mission and vision to encourage interprofessional collaboration, motivation, and engagement (AANA, 2019).

\section{Form a Powerful Guiding Coalition}

Forming a powerful guiding coalition created an interprofessional project leadership team to drive the perioperative providers to effective and sustainable change (Applebaum et al., 2012; Small et al., 2016). The leadership team included the project manager, key stakeholders, and champions selected from specialties including anesthesia, surgical office staff, and perioperative nursing. The champions played an important role in facilitating education and communication among their specialty to increase knowledge, awareness, and sustainability of the pathway. Four champions were selected based on their ability to: (a) discuss the value of the intervention, (b) inspire and direct perioperative team, (c) foster trust in the process, (d) build and sustain professional relationships, and (e) communicate effectively (Applebaum et al., 2012; Small et al., 2016). This stage represented the "plan" phase of the PDSA model.

\section{Create a Compelling Vision for Change}

Once the powerful guiding coalition was formed, the mission and vision of the project were finalized. The leadership team collaborated and considered the SWOT analysis (see Figure 3 for the SWOT analysis for this project) and CARI tool outcomes. These results were the strategic basis for creating a vision and a successful change process. The vision was clear enough that the perioperative providers recognized their positive impact on the outcomes (Applebaum et al., 2012; Small et al., 2016). The collaboration created clarity regarding the change project, role identification, accountability, and transparency (Small et al., 2016). 


\section{PAIN CONTROL OPTIMIZATION PATHWAY}

The vision considered the intervention and necessary resources including information and knowledge, the communication plan, perioperative providers, time, equipment, and costs (AANA, 2019; Small et al., 2016). For knowledge acquisition, provider resources described the care process, including preoperative patient counseling, intraoperative management, postoperative counseling, and standardized procedure-specific prescribing (see Figure 2 and Appendix C). The communication plan included verbal and visual materials and the frequency of oral and written communication channels, all based on project leadership team preferences. Connections were made between the vision and perioperative providers to facilitate a commitment to the change process. Equipment and costs were identified at the onset and continuously assessed to ensure availability. A summary of the vision and strategic plan was developed into a brief verbal and visual presentation and presented to champions (Mindtools, 2020).

\section{Communicate a Compelling Vision for Change}

Champions communicated the change project's mission and vision to perioperative providers in a brief verbal and nonverbal overview, which stimulated a climate for change (Applebaum et al., 2012; Small et al., 2016). During this phase, "buy-in” from the perioperative providers was of utmost importance (AANA, 2019). The champions served as communication lines between the project leadership team and perioperative providers during staff meetings. Concerns and fears were openly addressed, constructive feedback encouraged, and the communication plan described and followed. The goal was motivation by preparation, making the process rewarding, and valuing providers' work.

\section{Empower Action, Remove Obstacles}




\section{PAIN CONTROL OPTIMIZATION PATHWAY}

During this phase, the care process was introduced into practice. The "do" phase of the PDSA model was also executed. Obstacles were preemptively identified to ensure the perioperative providers' success (Applebaum et al., 2012; Small et al., 2016). The project leadership team addressed challenges and provided support to the perioperative providers, thus facilitating empowerment and motivation to move forward. The project's staff-related barriers were provider resistance to change, the time required for patient counseling, communication, collaboration inefficiencies among the team, and lack of skills or competencies (AANA, 2019). To address provider resistance to change, formal training was offered with verbal and visual educational resources focusing on scientific evidence supporting the change and the dire need to overcome the opioid epidemic. Patient-related barriers included health literacy, understanding engagement, and overcoming bias related to opioid-sparing techniques (AANA, 2019). To overcome this barrier, education took place during the three perioperative phases with both verbal and visual materials. Facility-related barriers included local changes in policy and procedures, staffing changes, ability to maintain continuous staff education, and availability of opioid-sparing medications (AANA, 2019). The strong interprofessional leadership team and strategic implementation plan were aimed at overcoming these obstacles.

\section{Create Short-Term Wins}

Setting short-term goals allowed for clear and visible wins, thus creating momentum in the project (Applebaum et al., 2012; Mindtools, 2020; Small et al., 2016). The goal was to increase providers' confidence in the program and potentially gain support from late adopters (Small et al., 2016). To implement this step, weekly emails were sent by the project manager to the project leadership team with the project status, including outcomes, provider compliance, and recognition of teams and individuals for their efforts. This phase entered the "study" phase of the 


\section{PAIN CONTROL OPTIMIZATION PATHWAY}

PDSA model. These weekly emails also facilitated and encouraged interprofessional communication and feedback.

\section{Consolidate and Build on Change}

The momentum from short-term wins was utilized to build on positive aspects of the project and identify areas in need of improvement (Applebaum et al., 2012; Small et al., 2016). To execute this step, the leadership team collaborated face-to-face monthly and considered outcome data, process measures, and feedback from perioperative providers to determine whether the outcomes were desirable. This information was communicated to perioperative providers by champions and included in weekly emails from the project manager.

\section{Anchor Changes into Organization and Team Culture}

To anchor the change into the organization, ongoing recognition, recruiting, and staff education was vital (Applebaum et al., 2012; Small et al., 2016). To execute this step, the champions continued to discuss the project at staff meetings and new employees were oriented to the process. The pathway is currently being formalized and translated into other surgical specialties. This coincided with the "act" phase of the PDSA model.

This evidence-based change project was developed, implemented, evaluated, and disseminated over 45 weeks and a detailed project schedule is presented in Appendix D. There were minimal costs to the organization for the project as the DNP student volunteered her time to formally train the interprofessional leadership team during the normally scheduled educational time, no staffing coverage was necessary at the practice setting, and statistician costs were paid for by the DNP student. Communication between the champions and perioperative providers took place during staff meetings requiring no staffing coverage. A monthly meeting of the 


\section{PAIN CONTROL OPTIMIZATION PATHWAY}

interprofessional leadership team was during regularly scheduled surgical service departmental meetings. Table 2 presents the final budget with consideration of direct and indirect costs.

\section{Evaluation Results}

This pre- and post-intervention evaluation was deemed an evidence-based practice change project by The University of St. Augustine for Health Sciences Evidence-Based Practice Review Council; the Beaumont Nursing Evidence-Based Practice, Quality, and Research Council; and the Beaumont Institutional Review Board.

Efforts to implement ethical practices throughout the intervention included the protection of the safety and rights of participants by de-identification of data. Secure computer programs and equipment were used to protect personal health information and contact information (phone numbers). All de-identified data was kept in a regulatory binder in a locked office (see Appendix E and Appendix F). Also, digital information was kept safe in a password-protected computer in a facility approved SharePoint per policy. Necessary information was destroyed after use and no conflicts of interest were noted. Furthermore, the project manager stored all data and directly obtained missing information from the secure EHR or patient. No recruited participants were removed from the project.

Surgery office staff oversaw the selection of participants without any issues regarding recruitment. Inclusion criteria included opioid-naïve patients undergoing uncomplicated, minimally invasive outpatient abdominal wall hernia surgeries within the defined time period. Exclusion criteria included: (a) complicated surgical course and multiple co-morbidities, (b) opioid use for chronic pain, (c) high-risk behaviors, (d) allergies, medical conditions, or personal reservations contradicting the use of acetaminophen or ibuprofen, and (e) current medications with adverse or synergistic interactions with perioperative pain management. The surgery office 


\section{PAIN CONTROL OPTIMIZATION PATHWAY}

staff were instructed to notify the project manager every week regarding participant recruitment and surgery dates.

The approaches used to determine how effectively the intervention impacted the practice problem included selecting quality outcome measures, a link between the intervention and practice problem, and utilization of appropriate statistical analysis to compare pre- and postintervention data. The primary outcomes evaluated were postoperative pain scores and opioid consumption variables, since these are driving forces in the opioid epidemic.

Postoperative pain scores were the key data source evaluated pre- and post-intervention to assess the practice change's effectiveness during the perioperative period. Upon discharge from the PACU, pain scores were collected from a chart review in the EHR and after 72-hours through a phone call (see Appendix E). The instrument utilized to collect pain scores was the 10point NRS (see Figure 4), which is validated in the literature (Sylvia \& Terhaar, 2018). Other primary outcomes included the prescription of a standard procedure-specific opioid, opioid consumption details, and patient satisfaction with the POP care process. This data was collected 72-hours after discharge and documented with an internally designed tool by the project leadership team (see Appendix E). The survey asked four "yes or no" questions, and there is no current test for reliability and validity. However, the intention was to develop the tool for future projects. To ensure the data collection process's consistency and accuracy, the project manager directly obtained the data using facility approved protocols and data collection tools.

Simple random sampling was used to collect pre-intervention baseline data retroactively from the EHR for 4 weeks before the intervention. The pain scores on a 10-point NRS scale at discharge from PACU averaged 4.8 pre-intervention. Also, $73 \%$ of eligible patients have prescribed a standard procedure-specific opioid prescription. Post-intervention data was collected 


\section{PAIN CONTROL OPTIMIZATION PATHWAY}

for pain scores over the intervention period and presented as a 30-day mean, 31-60 day mean, and 0-60 day mean. Post-intervention data regarding procedure-specific opioid prescriptions were collected and presented for the entire time period.

Twenty-eight opioid-naïve adult patients undergoing general anesthesia for out-patient, minimally invasive abdominal wall hernia surgery received the opioid-sparing acute pain management technique, and procedure-specific opioid prescribing. For primary outcome data (postoperative pain scores at discharge from the PACU), a two-tailed one-sample $z$-test was used to evaluate pre-intervention and post-intervention data and analyze whether mean pain scores would be produced by a probability distribution with a mean of 4.8 (baseline). Furthermore, the Shapiro-Wilk test was conducted to assess whether the post-intervention data could have been produced through normal distribution.

Thirteen patients received the intervention during the first 30 days and the mean pain score at discharge from the PACU was 2.62. Results of the two-tailed one-sample $z$-test were significant based on an alpha value of $0.05, z=-15.56, p<0.001$; results are presented in Table 3 .

\section{Table 3}

0-30 Day Two-Tailed One Sample z-Test for the Difference between Pain Score at Discharge from PACU and baseline (4.8)

\begin{tabular}{lccccc}
\hline Variable & $\mathrm{M}$ & $\mathrm{SD}$ & $\mu$ & $\mathrm{z}$ & $\mathrm{p}$ \\
\hline PainScoreDischarge & 2.62 & 0.51 & 4.8 & -15.56 & $<.001$ \\
\hline
\end{tabular}

Note. $\mathrm{N}=13$.

The Shapiro-Wilk test was also significant based on an alpha value of $0.05, W=0.63, p<0.001$, suggesting the data was not normally distributed. 


\section{PAIN CONTROL OPTIMIZATION PATHWAY}

During days 31 to 60,15 patients received the intervention and the mean pain score at discharge from the PACU was 3.0. The results were significant based on an alpha value of 0.05, $z=-9.22, p<0.001$ and are presented in Table 4

\section{Table 4}

31-60 Day Two-Tailed One Sample z-Test for the Difference between Pain Score at Discharge from PACU and baseline (4.8)

\begin{tabular}{lccccc}
\hline Variable & $\mathrm{M}$ & $\mathrm{SD}$ & $\mu$ & $\mathrm{z}$ & $\mathrm{p}$ \\
\hline Pain Score Discharge & 3.00 & 0.76 & 4.8 & -9.22 & $<.001$ \\
\hline
\end{tabular}

Note. $\mathrm{N}=15$.

The Shapiro-Wilk's test results were also significant based on an alpha value of $0.05, W=0.82$, $p=0.007$, signifying the normality assumption violated.

Collectively, the data from days zero to 60 related to pain scores at discharge from the PACU were analyzed. The post-intervention mean score was 2.82 , nearly half of the baseline mean score of 4.8. This is an analysis from a two-tailed one-sample $z$-test, showing a statistically significant difference, $p<0.001$ (see Table 5).

\section{Table 5}

0-60 Day Two-Tailed One Sample z-Test for the Difference between Pain Score at Discharge from PACU and baseline (4.8)

\begin{tabular}{lccccc}
\hline Variable & $\mathrm{M}$ & $\mathrm{SD}$ & $\mu$ & $\mathrm{z}$ & $\mathrm{p}$ \\
\hline Pain Score Discharge & 2.82 & 0.67 & 4.8 & -15.63 & $<.001$ \\
\hline
\end{tabular}

Note. $\mathrm{N}=28$.

These results show a statistically significant reduction in mean pain scores at discharge from the PACU post-intervention. 


\section{PAIN CONTROL OPTIMIZATION PATHWAY}

Postoperative pain scores were also collected after 72-hours and compared to scores at discharge using a two-tailed paired samples $t$-test for the entire 60-day intervention period. The mean pain score at discharge was 2.82 and 1.68 at 72-hours. Results were statistically significant $(p<0.001)$, indicating the mean pain score at discharge was significantly higher than after 72hours (see Table 6).

\section{Table 6}

Two-Tailed Paired Samples t-Test for the Difference Between Pain Score at Discharge and Pain Score After $72 \mathrm{hr}$

\begin{tabular}{ccccccc}
\hline \multicolumn{2}{l}{ Pain Score Discharge } & \multicolumn{2}{l}{ PainScore_72hr } & & & \\
& & & & & \\
M & SD & $\mathrm{M}$ & $\mathrm{SD}$ & $\mathrm{t}$ & $\mathrm{p}$ & $\mathrm{d}$ \\
\hline 2.82 & 0.67 & 1.68 & 0.61 & 7.13 & $<.001$ & 1.35 \\
& & & & & & \\
\hline
\end{tabular}

Note. $\mathrm{N}=28$. Degrees of Freedom for the t-statistic $=27 . \mathrm{D}$ represents Cohen's $\mathrm{d}$.

The Shapiro-Wilk test was significant, $p=0.002$, showing differences were unlikely to result from a normal distribution. However, Levene's test was not significant, $p=1.000$, suggesting homogeneity of variance was met. Together, evaluation of this outcome data suggests the intervention reduces pain in the immediate postoperative period and provides a care process to continue controlling pain over the next 72-hours (see Figure 5).

Outcome data related to opioid prescribing, consumption, and satisfaction was obtained 72-hours after the patient was discharged via a four-question phone survey and descriptive statistics used to summarize the data (see Table 7). Frequencies and percentages were calculated based on each question: (a) Were you prescribed a standard procedure-specific opioid prescription? (b) Did you consume your entire prescription? (c) Did you properly dispose of extra opioid pills, and (d) Were you satisfied with your acute postoperative pain management technique? Post-intervention results showed that $100 \%$ of patients were prescribed a standard 


\section{PAIN CONTROL OPTIMIZATION PATHWAY}

procedure-specific opioid, which is a significant increase from the pre-intervention $73 \%$ compliance. Eighty-two percent of patients did not consume their entire opioid prescription, of which, $78.57 \%$ properly disposed of the opioids. Furthermore, $100 \%$ of patients were satisfied with the acute pain management technique. This data shows that the evidence-based change projected influenced providers' knowledge and behavior, increased compliance with procedurespecific opioid prescribing practices, and educated and empowered patients to be satisfied with opioid-sparing techniques. Ultimately, the results show that there should be an increased emphasis placed on the proper disposal of opioids.

While evaluating outcomes identified in the PICOT question showed statistical significance, it is more critical to consider the project findings' clinical and practical significance. Clinical significance is important in EBP projects since it reflects the impact and magnitude of the intervention and whether the outcomes are clinically important, making it prudent for patient care (Ranganathan et al., 2015). This EBP change project had practical significance since providers viewed the intervention as an effective and efficient care process for delivering safe and high-quality perioperative pain management, with no increased burden. Additionally, the project leadership team has plans to continue the implementation since the adherence to the POP care process has met most pre-intervention goals, the feedback was positive, and patients' behaviors have shown proactive change.

The intervention had clinical significance as it improved health outcomes for patients in the short- and long-term. The intervention immediately controlled acute postoperative pain, improved patient knowledge regarding non-opioid pain control, focused on functional recovery

goals, and produced satisfactory pain management. The new practice also reduced patient opioid use and decreased opioid supply in the community. Each of these outcomes facilitates patient 


\section{PAIN CONTROL OPTIMIZATION PATHWAY}

engagement and empowerment, which are key factors in delivering patient-centered care. As for long-term effects, this intervention contributes to reducing the risk of long-term opioid misuse or overdose, making it critical in mitigating the opioid epidemic. The intervention is also clinically significant since it did not present documented adverse patient events and reduced side effects associated with opioid use.

Descriptive statistics were used to analyze population measures, including gender, age, the American Society of Anesthesiology (ASA) classification, and body mass index (BMI), and race (see Appendix E). Summary statistics were calculated for interval and ratio variables, while frequencies and percentages were calculated for each nominal variable. Results for nominal variables (race and gender) are presented in Table 8.

\section{Table 8}

Frequency Table for Nominal Variables

\begin{tabular}{lrr}
\hline Variable & $n$ & $\%$ \\
\hline Race & 22 & 78.57 \\
White & 4 & 14.29 \\
African American & 2 & 7.14 \\
Asian & 0 & 0.00 \\
Missing & & \\
Gender & 4 & 14.29 \\
female & 24 & 85.71 \\
male & 0 & 0.00 \\
Missing & 0 & \\
\hline
\end{tabular}

Note. Due to rounding errors, percentages may not equal $100 \%$.

The most frequently observed race was white $(n=22,79 \%)$, while the most prominent gender was male $(n=24,86 \%)$. Summary statistics for interval and ratio variables averaged to an age of 65.11, ASA classification 2.82, and BMI 28.39 (see Table 9). 
PAIN CONTROL OPTIMIZATION PATHWAY

Table 9

Summary Statistics Table for Interval and Ratio Variables

\begin{tabular}{lrrrrrrrr}
\hline Variable & $\mathrm{M}$ & $\mathrm{SD}$ & $\mathrm{n}$ & $\mathrm{SE}_{\mathrm{M}}$ & $\mathrm{Min}$ & $\mathrm{Max}$ & Skewness & Kurtosis \\
\hline Age & 65.11 & 10.64 & 28 & 2.01 & 43.00 & 82.00 & -0.35 & -0.81 \\
AS Classification & 2.82 & 0.39 & 28 & 0.07 & 2.00 & 3.00 & -1.68 & 0.82 \\
BMI & 28.39 & 4.18 & 28 & 0.79 & 21.00 & 38.00 & 0.05 & -0.54 \\
\end{tabular}

Note. This indicates the statistic is undefined due to constant data or insufficient sample size.

The descriptive statistics were collected to summarize and describe the data and understand whether patient-specific demographic variables influenced pain and opioid use with the multimodal, opioid-sparing acute pain management technique; no significant relationships were observed. Therefore, this data serves as a foundation for understanding the population and aids in transitioning to additional populations or generalizing to larger populations.

Process measures included: (a) perioperative provider compliance with utilizing an opioid-sparing, multimodal technique as first-line treatment for acute pain, (b) perioperative provider compliance with preoperative patient counseling, (c) perioperative provider compliance with postoperative patient counseling, and (d) percent compliance with utilizing of standardized procedure-specific opioid prescribing (see Appendix F). During the first 30 days, $92.3 \%$ of providers were compliant with using the opioid-sparing multimodal technique, $100 \%$ of providers performed preoperative counseling, $84.6 \%$ performed postoperative counseling, and $100 \%$ of providers utilized a standard procedure-specific opioid prescription. During days 31-60, $86.7 \%$ of providers were compliant with using the opioid-sparing multimodal technique, $93.3 \%$ of providers performed preoperative counseling, $86.7 \%$ performed postoperative counseling, and $100 \%$ of providers utilized a standard procedure-specific opioid prescription. These measures 


\section{PAIN CONTROL OPTIMIZATION PATHWAY}

represent steps in the POP care process that lead to statistically and clinically significant outcomes and serve as the foundation for sustainability. Provider compliance with using the opioid-sparing technique incorporates the need for rescue opioids during the process, and three patients required this intervention. Upon review, this was deemed appropriate care based on the patients' clinical status and considered an unavoidable outcome. The $100 \%$ compliance with preoperative counseling shows strong provider education and planning and will aid in sustainability. Postoperative counseling ranged from $84.6 \%$ to $86.7 \%$, and upon follow-up, providers stated time constraints were the reason for non-compliance. The complete provider compliance with utilizing standard procedure-specific opioid prescriptions proves the success of planning and implementation, along with a positive outlook for sustainability.

Balancing measures included ensuring the rate of unintended hospitalization and readmission rates, neither of which increased. Therefore, it may be assumed this evidence-based change did not negatively impact other areas within the organization. Financial measures included provider education and training costs, which were minimal and covered by the DNP student. Sustainability measures were embedded into the evidence-based change project, emphasizing compliance with on-going training of providers, patient counseling, and compliance with procedure-specific opioid prescribing.

\section{Impact}

Assumptions based on scientific evidence that implementation of the POP care process for opioid-naïve patients undergoing minimally invasive, out-patient abdominal wall hernia surgery would decrease pain scores and reduce opioid consumption was supported in this evidence-based change project. Results showed the POP care process, which utilizes an opioidsparing acute pain management technique, preoperative and postoperative patient counseling, 


\section{PAIN CONTROL OPTIMIZATION PATHWAY}

and standardized procedure-specific opioid prescribing, positively impacted patient outcomes and is an important step in battling the opioid epidemic. It alters practice by providing an alternative care process for acute postoperative pain that reduces side effects associated with opioids, reduces the risk of persistent opioid use, and provides adequate pain relief using multiple pharmacological and non-pharmacological treatment modalities.

The POP care process has a significant impact on nursing and healthcare, as it supports interprofessional collaboration and strong patient-provider relationships. It engages and empowers both providers and patients to participate in combating the opioid epidemic by focusing on an opioid-sparing perioperative course, functional recovery goals, and standardized procedure-specific opioid prescribing. The care process provides safe and effective acute postoperative pain control but considering the linkage between acute and long-term opioid use, it is vital to reduce the risk of opioid misuse, diversion, and overdose-related deaths.

As this change project provided a reliable cause-and-effect relationship between intervention and outcome, the project leadership team is devoted to continuing future intervention. To ensure the intervention's sustainability, the project leadership team is working with information technology to implement a clinical decision support tool with an alert for perioperative providers in the facility EHR to discuss opioid-sparing pain management options with patients. Also, written and verbal information regarding the POP care process is integrated into the organization's new employee orientation curriculum. Lastly, leaders within the organization have adopted the protocol and are implementing it within various surgical specialties. For ongoing evaluations, the Director of Anesthesia has volunteered to take the project manager role. The project leadership team will continue to meet monthly and communicate directly with the project champions. 


\section{PAIN CONTROL OPTIMIZATION PATHWAY}

To further improve the POP care process's effect on battling the opioid epidemic, the focus will be on transitioning to other surgical specialties, formalizing the facility EHR protocol, and improving the data collection tools. Limitations included a lack of data regarding the anesthetic technique and site-specific regional blockade. Recommendations for replicating this project include data collection on specific medications administered during the perioperative period and regional blockade documentation. The site-specific regional blockade should be documented, including the type of local anesthetic, concentration, dose, and site. This has the potential to greatly influence the longevity of pain management. Also, the exact number of opioid pills consumed should be documented, as zero to ten pills is a large range. Lastly, an emphasis should be placed on education regarding the safe disposal of opioids, including the importance of take-back events that prevent opioid abuse before it starts.

\section{Plans for Dissemination}

To share the evidence-based change project results within the organization, the project has been presented to the interprofessional leadership team and perioperative providers involved with the intervention. The providers were invited via email to the presentation during regular departmental meeting times and locations. Three separate presentations were given to the surgery office staff, the perioperative nursing team, and anesthesia providers at their designated locations. The presentation included a verbal overview, visual aids (poster), handouts, and interactive discussion time.

Moving forward, the leadership team will collectively prepare an abstract and poster to be presented at the organization's quality improvement conference. A presentation will also be given to the organization's research institute with anticipation to be reported in the 2020 accomplishments. This organization has reported quality and safety results that improve patient 


\section{PAIN CONTROL OPTIMIZATION PATHWAY}

care and outcomes for over 50 years; therefore, it is anticipated the results of this change project will be valuable.

To share the results with the professional community, the change project will be archived at the University of St. Augustine for Health Sciences Scholarship and Open Access Repository (SOAR@USA) for student and faculty access. A poster will also be presented at the Spring 2021 Michigan Association of Nurse Anesthetists (MANA) conference virtually in Detroit, Michigan. The American Association of Nurse Anesthetist Journal has been selected for publication. The journal has a peer-review process for submission; however, the interprofessional leadership team is also reviewing the manuscript before submission. This journal is published bi-monthly and delivers clinical practice information to anesthesia providers regarding innovations in nurse anesthesia practice, which is aligned with the goals of the intervention.

\section{Conclusion}

The POP care process developed by Michigan OPEN is an interdisciplinary and evidence-based approach to preventing harm and reducing long-term opioid use among surgical patients. It improves postoperative outcomes by providing an effective and efficient acute pain management plan, decreasing the surplus of opioids in the community, and educating patients. In the face of the opioid epidemic, this change project utilized the POP care process to deliver highquality and safe care during the perioperative period. The care process incorporated preoperative patient counseling, intraoperative management, and postoperative counseling. Patient counseling focused on patient engagement and empowerment with knowledge regarding expectations, an opioid-sparing technique, and the adverse effects of opioids. Intraoperative management utilized a multimodal, opioid-sparing technique as first-line management. Postoperative counseling reinforced communication regarding functional pain management goals, instructions for non- 


\section{PAIN CONTROL OPTIMIZATION PATHWAY}

opioids adjuncts, acetaminophen and ibuprofen scheduling, and safe use of opioids for breakthrough pain. It was important providers complied with standardized procedure-specific opioid prescribing to reduce exposure and access to opioids.

This study's results are aligned with current literature, thus supporting a POP care process for managing acute pain and reducing opioid consumption after minimally invasive hernia surgery among opioid-naïve patients. To aid in compliance and sustainability, initial provider education and ongoing training continue to be essential. Additional rigorous studies comparing multimodal, opioid-sparing techniques, focusing on regional anesthesia, evaluating components of patient counseling, and assessing provider training methods may strengthen the translation into other surgical specialties and patient populations. 


\section{PAIN CONTROL OPTIMIZATION PATHWAY}

\section{References}

Access Oakland. (2017). Prevent prescription drug abuse.

https://accessoakland.oakgov.com/pages/oakland-county-opioid-initiative

American Academy of Pain Medicine. (2019). Chronic pain, couples, and physical activity. https://painmed.org/clinical-trials-and-funding/chronic-pain-couples-physical-activity

American Association of Nurse Anesthetists. (2019). Enhanced recovery after surgery. https://www.aana.com/practice/clinical-practice-resources/enhanced-recoveryafter-surgery

Applebaum, S. H., Habashy, S., Malo, J., \& Shafiq, H. (2012). Back to the future: Revisiting Kotter's 1996 change model. Journal of Management Development, 31(8), 764-782. https://doi.org/10.1108/02621711211253231

Bajwa, Z. H., Wootton, R. J., \& Warfield, C. A. (2017). Principles and practice of pain medicine ( $3^{\text {rd }}$ ed.). McGraw-Hill Medical Education. https://accessanesthesiology.mhmedical.com/book.aspx?bookid=1845

Barwicjk, M.A. (2011). Checklist to Assess Organizational Readiness (CARI) for EIP implementation. Effective Services. https://www.effectiveservices.org/downloads/Checklist_to_Assess_Organisational_Readi ness_for_Implementation.pdf

Beaumont. (2020). About us. https://www.beaumont.org/about-us

Bendinger, T. \& Plunkett, N. (2016). Measurement in pain medicine, BJA Education, 16(9), 310315. https://doi.org/10.1093/bjaed/mkw014

Bickett, M. C., Long, J. J., Pronvost, P. J., Alexander, G. C., \& Wu, C. L. (2017). Prescription 


\section{PAIN CONTROL OPTIMIZATION PATHWAY}

opioid analgesics commonly unused after surgery: A systematic review. JAMA Surgery, 152(11), 1066-1071. https://doi.org/10.1001/jamasurg.2017.0831

Bingener, J., Skaran, P., McConico, A., Novotny, P., Wettstein, P., Sletten, D. M., Park, M., Low, P., \& Sloan, J. (2015). A double-blinded randomized trial to compare the effectiveness of minimally invasive procedures using patient-reported outcomes. Journal of the American College of Surgeons, 221(1), 111-121. https://doi.org/10.1016/j.jamcollsurg.2015.02.022

Brandal, D., Keller, M. S., Lee, C., Grogan, T., Fujimoto, Y., Gricout, Y., Yamada, T., Rahman, S., Hofer, I., Kazanjian, K., Sack, J., Aman, M., Lin, A., \& Cannesson, M. (2017). Impact of enhanced recovery after surgery and opioid-free anesthesia on opioid prescriptions at discharge from the hospital: A historical-prospective sturdy. Anesthesia \& Analgesia, 125(5), 1784-1792. https://doi.org/10.1213/ANE.0000000000002510

Centers for Disease Control and Prevention. (2019). National center for health statistics. https://www.cdc.gov/nchs/index.htm

Chapman, J. S., Roddy, E., Ueda, S., Brooks, R., Chen, L. L., \& Chen, L. M. (2016). Enhanced recovery pathways for improving outcomes after minimally invasive gynecologic oncology surgery. Obstetrics \& Gynecology, 128(1), 138-144. https://doi.org/10.1097/AOG.0000000000001466

Chou, R., Gordon, D. B., de Leon-Cassola, O. A., Rosenberg, J. M., Bicker, S., Brennan, T., Carter, T., Cassidy, C. L., Chittenden, E. H., Degenhardt, E., Griffith, S., Manworren, R., McCarberg, B., Montgomery, R., Murphy, J., Perkal, M. F., Suresh, S., Sluka, K., Strassels, S., \& Wu, C. L. (2016). Management of postoperative pain: A clinical practice guideline from the American Pain Society, the American Society of Regional Anesthesia 


\section{PAIN CONTROL OPTIMIZATION PATHWAY}

and Pain Medicine, and the American Society of Anesthesiologists' Committee on Regional Anesthesia, Executive Committee, and Administrative Council. The Journal of Pain, 17(2), 131-157. https://doi.org/10.1016/j.jpain.2015.12.008

Clark, D. J., \& Schumacher, M. A. (2017). America's opioid epidemic: Supply and demand considerations. Anesthesia \& Analgesia, 125(5), 1667-1674. https://doi.org/10.1213/ANE.0000000000002388

Dearholt, S. L. \& Dang, D. (2018). Johns Hopkins nursing evidence-based practice: Model and Guidelines ( $3^{\text {rd }}$ ed.) Sigma Theta Tau International.

Degenhardt, L., Charlson, F., Mathers, B., Hall, W. D., Flaxman, A. D., Johns, N., \& Vos, T. (2014). The global epidemiology and burden of opioid dependence: Results from the global burden of disease 2010 study. Addiction, 109, 1320-1333. https://doi.org/10.1111/add.12551

Echeverria-Villalobos, M., Stoicea, N., Todeschini, A. B., Fiorda-Diaz, J., Uribe, A. A., Weaver, T., \& Bergese, S. D. (2019). Enhanced recovery after surgery (ERAS): A perspective review of postoperative pain management under ERAS pathways and its role on opioid crisis in the United States. Clinical Journal of Pain, 36(3). https://doi.org/10.1097/AJP.0000000000000792

Esteban, F., Cerdan, F. J., Garcia-Alonso, M., Sanz-Lopez, R., Arroyo, A., Ramirez, J. M., Moreno, C., Morales, R., Navarro, A., \& Fuentes, M. (2014). A multicenter comparison of a fast track or conventional postoperative protocol following laparoscopic or open elective surgery for colorectal cancer surgery. Colorectal Disease, 16(2), 134-140. https://doi.org/10.1111/codi.12472

Feinberg, A. E., Chesney, T. R., Srikandarajah, S., Acuna, S. A., McLeod, R. S., \& Best Practice 


\section{PAIN CONTROL OPTIMIZATION PATHWAY}

in Surgery Group. (2018). Opioid use after discharge in postoperative patients: A systematic review. Annals of Surgery, 267(6), 1056-1062.

https://doi.org/10.1097/SLA.0000000000002591

Field, A. (2018). Discovering statistics using IBM SPSS statistics $\left(5^{\text {th }} \mathrm{ed}.\right)$. SAGE publications.

Gan, T. J. (2017). Poorly controlled postoperative pain: Prevalence, consequences, and prevention. Journal of Pain Research, 10, 2287-2298. https://doi.org/10.2147/JPR.S144066

Hah, J. M., Bateman, B. T., Ratliff, J., Curtin, C., \& Sun, E. (2017). Chronic opioid use after surgery: Implications for perioperative management in the face of the opioid epidemic. Anesthesia \& Analgesia, 125(5), 1733-1740. https://doi.org/10.1213/ANE.0000000000002458

Hallway, A., Vu, J., Lee, L., Palazzolo, W., Waljee, J., Brummett, C., Englesbe, M., \& Howard, R. (2019). Patient Satisfaction and pain control using an opioid-sparing postoperative pathway. Journal of the American College of Surgeons, 229(3), 316-322. https://doi.org/10.1016/j.jamcollsurg.2019.04.020

Harryman, C., Plymale, M. A., Stearns, E., Davenport, D. L, Chang, W., \& Roth, J. S. (2019). Enhanced value with implementation of ERAS protocol for ventral hernia repair. Surgical Endoscopy, 10(1). https://doi.org/10.1007/s00464-019-07166-2

Interprofessional Education Collaborative. (2016). Core competencies for interprofessional collaborative practice. https://hsc.unm.edu/ipe/resources/ipec-2016core-competencies.pdf

Jensen, K. K., Brondum, T. L., Harling, H., Kehlet, H., \& Jorgensen, L. N. (2016). Enhanced 


\section{PAIN CONTROL OPTIMIZATION PATHWAY}

recovery after giant ventral hernia repair. Hernia, 20(2), 249-256.

https://doi.org/10.1007/s10029-016-1471-0

Kalogera, E., Glaser, G. E., Kumar, A., Dowdy, S. C., \& Langstraat, C. L. (2019). Enhanced recovery after minimally invasive gynecologic procedures with bowel surgery: A systematic review. Journal of Minimally Invasive Gynecology, 26(2), 288-298. https://doi.org/10.1016/j.jmig.2018.10.016

Kalogera, E. \& Dowdy, S. C. (2019). Enhanced recovery after surgery and acute postoperative pain management. Clinical Obstetrics and Gynecology, 62(4), 656-665. https://doi.org/10.1097/GRF.0000000000000475

Kennedy, R. H., Francis, E. A., Wharton, R., Blazeby, J. M., Quirke, P., West, N. Sutton, S. J. (2014). Multicenter randomized controlled trial of conventional versus laparoscopic surgery for colorectal cancer within an enhanced recovery programme: EnROL. Journal of Clinical Oncology, 32(17), 1804-1811. https://doi.org/10.1200/JCO.2013.54.3694

Knudsen, S. V., Laursen, H. V., Johnson, S. P., Bartels, P. D., Ehlers, L. H., \& Mainz, J. (2019). Can quality improvement improve the quality of care? A systematic review of reported effects and methodological rigor in plan-do-study-act-projects. BMC Health Services Research, 19, 683. https://doi.org/10.1186/s12913-019-4482-6

Kumar, K., Kirksey, M. A., Duong, S., \& Wu, C. L. (2017). A review of opioid-sparing modalities in perioperative pain management: Methods to decrease opioid use postoperatively. Anesthesia \& Analgesia, 125(5), 1749-1760. https://doi.org/10.1213/ANE.0000000000002497

Li, J., Kong, X. X., Zhou, J. J., Song, Y. M., Huang, X. F., Li, G. H., Ying, X. J., Dai, Z. Y., Lu, 


\section{PAIN CONTROL OPTIMIZATION PATHWAY}

M., Jiang, K., Fu, D. L., Li, X. L., He, J. J., Wang, J. W., Sun, L. F., Xu, D., Xu, J. Y., Chen, M., Tian, Y., ... \& Ding, K. F. (2019). Fast-track multidisciplinary treatment versus conventional treatment for colorectal cancer: A multicenter, open-label randomized controlled study. BMC Cancer, 19(1). https://doi.org/10.1186/s12885-019$\underline{6188-X}$

Longest, B. B., \& Daar, K. (2008). Managing health services organizations and systems (5 ${ }^{\text {th }}$ ed.). Health Professions Press.

Majumder, A., Fayezizadeh, M., Neupane, R., Elliott, H. L., \& Novitsky, Y. W. (2016). Benefits of multimodal enhanced recovery pathway in patients undergoing open ventral hernia repair. Journal of the American College of Surgeons, 222(6), 1106-1115. https://doi.org/10.1016/j.jamcollsurg.2016.02.015

Meyer, L., Lasala, J., Iniesta, M., Nick, A., Munsell, M., Shi, Q., Wang, X. S., Cain, K. E., Lu, K. H., \& Ramirez, P. (2018). Effect of an enhanced recovery after surgery program on opioid use and patient-reported outcomes. Obstetrics \& Gynecology, 132(2), 281-290. https://doi.org/10.1097/AOG.0000000000002735

Michigan Department of Health and Human Services. (2020). Vital statistics. https://www.michigan.gov/mdhhs/0,5885,7-339-73970_2944_4669---,00.html

Mitra, S., Carlyle, D., Kodumudi, G., Kodumudi, V., \& Vadivelu, V. (2018). New advances in acute postoperative pain management. Current Pain and Headache Reports, 2(22), 35. https://doi.org/10.1007/s11916-018-0690-8

Moher, D., Liberati, A., Tetzlaff, J., Altman, D.G., \& The PRISMA Group. (2009). Preferred Reporting Items for Systematic reviews and Meta-Analyses: The PRISMA statement. PLoS Med 6(7), e1000097. https://doi.org/10.1371/journal.pmed.1000097 


\section{PAIN CONTROL OPTIMIZATION PATHWAY}

Nassif, G. J., \& Miller, T. E. (2018). Evolving the management of acute perioperative pain towards opioid free protocols: A narrative review. Current Medical Research and Opinion, 35(12), 2129-2136. https://doi.org/10.1080/03007995.2019.1646001

Opioid Prescribing Engagement Network. (2020). Open reducing risks for safer communities. https://michigan-open.org/

Ozgur, K., Hakan, T., \& Ozgur, D. (2018). A systematic review of the pain scales in adults: Which to use? American Journal of Emergency Medicine, 36(4), 707-714. https://doi.org/10.1016/j.ajem.2018.01.008

Pache, B., Hubner, M., Jurt, J., Demartines, N., \& Grass, F. (2017). Minimally invasive surgery and enhanced recovery after surgery: The ideal combination? Journal of Surgical Oncology, 116(5), 613-616. https://doi.org/10.1002/jso.24787

Pogatzki-Zahn, E. M., Segelcke, D., \& Schug, S. A. (2017). Postoperative pain- from mechanisms to treatment. PAIN Reports, 2(2), e588. https://doi.org/10.1097/PR9.0000000000000588

Pino, C. A., \& Covington, M. (2019). Prescription of opioids for acute pain in opioid naïve patients. In S. Fishman (Ed.). UpToDate. https://www.uptodate.com/contents/prescription-of-opioids-for-acute-pain-in-opioidnaive-patients

Ramia, E., Nasser, S. C., Salameh, P., \& Saad, A. H. (2017). Patient perception of acute pain management: Data from three tertiary care hospitals. Pain Research and Management. https://doi.org/10.1155/2017/7459360

Ranganathan, P., Pramesh, C. S., \& Buyse, M. (2015). Common pitfalls in statistical 


\section{PAIN CONTROL OPTIMIZATION PATHWAY}

analysis: Clinical versus statistical significance. Perspectives in Clinical Research, 6(3), 169-107. https://doi.org/10.4103/2229-3485.159943

Shaikh, N., Tahseen, S., Haq, Q., Al-Ameri, G., Ganaw, A., Chanda, A., Labathkhan, M. Z., \& Kazi, T. (2018). Acute pain management in intensive care patients: Facts and figures. https://www.intechopen.com/books/pain-management-in-special-circumstances/acutepain-management-in-intensive-care-patients-facts-and-figures

Small, A., Gist, D., Souza, D., Dalton, J., Magny-Normilus, S., \& David, D. (2016). Using Kotter's change model for implementing bedside handoff. Nursing Care Quality, 31(4), 304-309. https://doi.org/10.1097/NCQ.0000000000000212

Smith, G. B., Belgamukar, A. P., Davidson, B. R., \& Gurusamy, K. S. (2016). Enhanced recovery protocols for major upper gastrointestinal, liver, and pancreatic surgery. Cochrane Database of Systematic Reviews, 1-50. https://doi.org/10.1002/14651858.CD011382.pub2

Soffin, E., Waldman, S., Stack, R., \& Liguori, G., A. (2017). An evidence-based approach to the prescription opioid epidemic in orthopedic surgery. Anesthesia \& Analgesia, 125(5), 1704-1713. https://doi.org/10.1213/ANE.0000000000002433

Spanjersberg, W. R., van Sambeek, J. D., Bremers, A., Rosman, C., \& van Laarhoven, C. J. (2015). Systematic review and meta-analysis for laparoscopic versus open surgery with or without an ERAS programme. Surgical Endoscopy, 29(12), 3443-3453. https://doi.org/10.1007/s00464-015-4148-3

Stearns, E., Plymale, M. A., Davenport, D. L., Totten, C., Carmichael, S. P., Tancula, C. S., 


\section{PAIN CONTROL OPTIMIZATION PATHWAY}

\& Roth, J. S. (2018). Early outcomes of an enhanced recovery protocol for open ventral hernia repair. Surgical Endoscopy, 32, 2914-2922. https://doi.org/10.1007/s00464-017-6004-0

Stepan, J. G., Lovecchio, F., Premkumar, A., Kahlenberg, C. A., Albert, T., Baurely, J., \& Nwachukwu, B. (2019). Development of an institutional opioid prescriber education program and opioid-prescribing guidelines: Impact on prescribing practices. The Journal of Bone and Joint Surgery, 101(1), 5-13. https://doi.org/10.2106/JBJS.17.01645Stone, R. (2018). Enhanced recovery after minimally invasive surgery (ERAmiS) for gynecology. Current Obstetrics and Gynecology Reports, 7, 39-50. https://doi.org/10.1007/s13669-018-0234-6

Sylvia, M. L. \& Terhaar, M. F. (2018). Clinical analytics and data management of the DNP ( $2^{\text {nd }}$ ed.). Springer.

Tan, M., Law, L. S., \& Gan, T. J. (2015). Optimizing pain management to facilitate enhanced recovery after surgery pathways. Canadian Journal of Anesthesia, 62(2), 203-218. https://link.springer.com/article/10.1007\%2Fs12630-014-0275-X

Taylor, M. J., McNicholas, C., Nicolay, C., Darzi, A., Bell, D., \& Reed, J. E. (2014). Systematic review of the application of the plan-do-study-act method to improve quality in healthcare. BMJ Quality \& Safety, 23, 290-298. https://qualitysafety.bmj.com/content/23/4/290

The Mindtools Content Team. (2020, March 8). Kotter's 8-Step Change Model. Mindtools. https://www.mindtools.com/pages/article/newPPM_82.htm

Trowbridge, E. R., Evans, S. L., Sarosiek, B. M., Modesitt, S. C., Redick, D. L., Tiouririne, M., 


\section{PAIN CONTROL OPTIMIZATION PATHWAY}

Thiele, R. H., Hendrick, T. L., \& Hullfish, K. L. (2019). Enhanced recovery program for minimally invasive and vaginal urogynecologic surgery. International Urogynecology Journal, 30(2), 313-321. https://doi.org/10.1007/s00192-018-3794-0

Ueland, W., Walsh-Blackmore, S., Nisiewicz, M., Davenport, D. L., Plymale, M. A., Plymale, M., \& Roth, J. S. (2019). The contribution of specific enhanced recovery after surgery (ERAS) protocol elements to reduce length of stay after ventral hernia repair. Surgical Endoscopy 7, 4638-4644. https://doi.org/10.1007/s00464-019-07233-8

Warren, J. A., Stoddard, C., Hunter, A. L., Horton, A. J., Atwood, C., Ewing, J. A., Pusker, S., Cancellaro, V. A., Walker, K. B., Cobb, W. S., Carbonell, A. M., \& Morgan, R. R. (2017). Effect of multimodal analgesia on opioid use after open ventral hernia repair. Journal of Gastrointestinal Surgery, 21(10), 1692-1699. https://doi.org/10.1007/s11605$\underline{017-3529-4}$

White, P. (2002). The role of non-opioid analgesic techniques in the management of pain after ambulatory surgery. Anesthesia \& Analgesia, 94(3), 577-585. https://doi/org/10.1097/00000539-200203000-00019

Wijk, L., Udumyan, R., Pache, B., Altman, A. D., Williams, L. L., Elias, K. M., McGee, J., Wells, T., Gramlich, L., Holcomb, K., Achtari, C., Ljungqvist, O., Dowdy, S. C., \& Nelson, G. (2019). International validation of enhanced recovery after surgery society guidelines on enhanced recovery for gynecologic surgery. American Journal Obstetrical Gynecology, 221(3), 237e1-237e11. https://doi.org/10.1016/j.ajog.2019.04.028

World Health Organization. (2018). Information sheet on opioid overdose. https://www.who.int/news-room/fact-sheets/detail/opioid-overdose

Yost, M. T., Jolissaint, J. S., Fields, A. C., \& Fisichella, P. M. (2018). Enhanced recovery 


\section{PAIN CONTROL OPTIMIZATION PATHWAY}

pathways for minimally invasive esophageal surgery. Journal of Laparoendoscopic \& Advanced Surgical Techniques, 28(3). https://doi.org/10.1089/lap.2018.0073

Zhou, J., Fan, Y., Zhong, J., Wen, X., \& Chen, H. (2017). Efficacy and safety of multimodal analgesic techniques for preventing chronic postsurgery pain under different surgical categories: a meta-analysis. Scientific Reports, 7, 678-690.

https://doi.org/10.1038/s41598-017-00813-5

Zhao, J. H., Sun, J. X., Huang, X. Z., Gao, P., Chen, X. W., Song, Y. X., Liu, J., Cai, C., Xu, H., \& Wang, Z. N. (2016). Meta-analysis of the laparoscopic versus open colorectal surgery with fast tract surgery. International Journal of Colorectal Disease, 31(3), 613-622. https://doi.org/10.1007/s00384-015-2493-2 
PAIN CONTROL OPTIMIZATION PATHWAY

Table 1

Perioperative Provider Responsibilities

\begin{tabular}{|c|c|c|c|c|c|c|}
\hline \multirow[t]{2}{*}{ PERIOPERATIVE PHASE } & \multicolumn{6}{|c|}{ RESPONSIBILITY } \\
\hline & Surgeons & $\begin{array}{l}\text { Surgery } \\
\text { Office Staff }\end{array}$ & $\begin{array}{l}\text { Preop } \\
\text { Nurses }\end{array}$ & Anesthesia & $\begin{array}{l}\text { Postop } \\
\text { Nurses }\end{array}$ & Patient \\
\hline \multicolumn{7}{|l|}{ Preoperative Phase } \\
\hline $\begin{array}{l}\text { Patient selection } \\
\text { (inclusion/exclusion) }\end{array}$ & $X$ & $\mathrm{X}$ & & & & $\mathrm{X}$ \\
\hline - $\quad$ Patient counseling & $X$ & $X$ & $\mathrm{X}$ & & & $X$ \\
\hline \multicolumn{7}{|l|}{ Operative Phase } \\
\hline - $\quad$ Patient counseling & & & & $\mathrm{X}$ & & $X$ \\
\hline $\begin{array}{l}\text { Multimodal, opioid-sparing } \\
\text { analgesia }\end{array}$ & $\mathrm{X}$ & & & $\mathrm{X}$ & & $\mathrm{X}$ \\
\hline \multicolumn{7}{|l|}{ Postoperative Phase } \\
\hline - Opioid-sparing analgesia & & & & & $X$ & $\mathrm{X}$ \\
\hline - Discharge education & & & & & $X$ & $\mathrm{X}$ \\
\hline $\begin{array}{l}\text { Procedure-specific opioid } \\
\text { prescription }\end{array}$ & $\mathrm{X}$ & & & & & $\mathrm{X}$ \\
\hline \multicolumn{7}{|l|}{ Continued Quality Improvement } \\
\hline $\begin{array}{l}\text { - Utilize data to celebrate } \\
\text { successes and identify areas of } \\
\text { improvement }\end{array}$ & $\mathrm{X}$ & $\mathrm{X}$ & $\mathrm{X}$ & $\mathrm{X}$ & $X$ & \\
\hline
\end{tabular}


Table 2

Budget

\begin{tabular}{|c|c|c|c|}
\hline EXPENSES & & REVENUE & \\
\hline Direct & & Billing & 0 \\
\hline $\begin{array}{l}\text { Salary and benefits: }(1) \\
\text { project manager (formal } \\
\text { training): } 5 \text { hours } \mathrm{x} \\
\$ 90 / \text { hour, }(2) \text { nurse } \\
\text { champions (formal training): } \\
4 \text { providers x } 1 \text { hour } \mathrm{x} \\
\$ 30 / \text { hour, }(3) \text { surgeon formal } \\
\text { training: } 2 \text { providers } x 1 \\
\text { hour } \mathrm{x} \$ 200 / \text { hour }\end{array}$ & $\$ 970$ & Grants & 0 \\
\hline $\begin{array}{l}\text { Supplies and materials: } \\
\text { laminated provider resources } \\
\& \text { patient handouts (paid by } \\
\text { DNP student/project } \\
\text { manager) }\end{array}$ & $\$ 200$ & Institutional budget support & 0 \\
\hline \multicolumn{4}{|l|}{ Services } \\
\hline Statistician & $\$ 200$ & & \\
\hline \multicolumn{4}{|l|}{ Indirect } \\
\hline $\begin{array}{l}\text { Overhead: educational space } \\
\text { for interprofessional team } \\
\text { meetings: } 6 \mathrm{hrs}\end{array}$ & 0 & & \\
\hline Total Expenses & $\$ 1,370$ & Total Revenue & 0 \\
\hline Net Balance $\$ 1,370$ & & & \\
\hline
\end{tabular}




\section{PAIN CONTROL OPTIMIZATION PATHWAY}

Table 7

Frequency Table for Nominal Variables

\begin{tabular}{lrr}
\hline Variable & $\mathrm{n}$ & $\%$ \\
\hline Prescribed Standard Procedure Specific Opioid Prescription & & \\
Yes & 28 & 100.00 \\
Missing & 0 & 0.00 \\
Consume Entire Prescription & & \\
No & 23 & 82.14 \\
Yes & 5 & 17.86 \\
Missing & 0 & 0.00 \\
Properly Discharge Of Opioid Pills & & \\
Yes & 22 & 78.57 \\
Na & 5 & 17.86 \\
No & 1 & 3.57 \\
Missing & 0 & 0.00 \\
Overall Satisfied With Pain Management Technique & & \\
Yes & 28 & 100.00 \\
Missing & 0 & 0.00
\end{tabular}

Note. Due to rounding errors, percentages may not equal $100 \%$. 
PAIN CONTROL OPTIMIZATION PATHWAY

\section{Figure 1}

PRISMA Flow Diagram
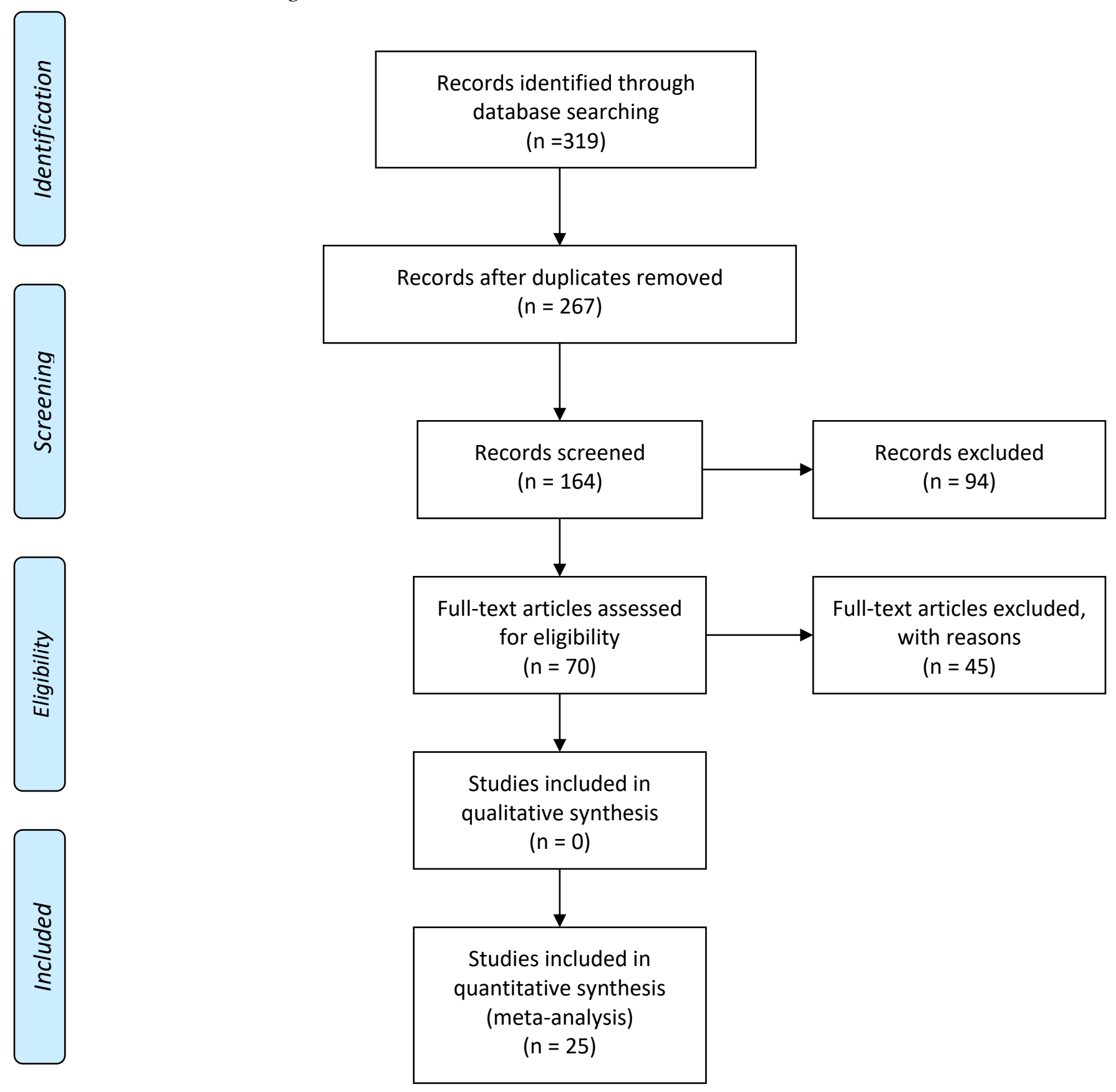


\section{PAIN CONTROL OPTIMIZATION PATHWAY}

Note. Adapted from "Preferred Reporting Items for Systematic Reviews and Meta-Analyses: The PRISMA Statement," by Moher D, Liberati A, Tetzlaff J, Altman DG, The PRISMA Group, 2009, PloS Med 6(7): e1000097 (https://doi.org/10.1371/journal.pmed1000097). Copyright 2009 by Creative Commons Attribution Non-Commercial License. 


\section{Figure 2}

Pain Control Optimization Pathway (POP) Perioperative Care Processes Overview

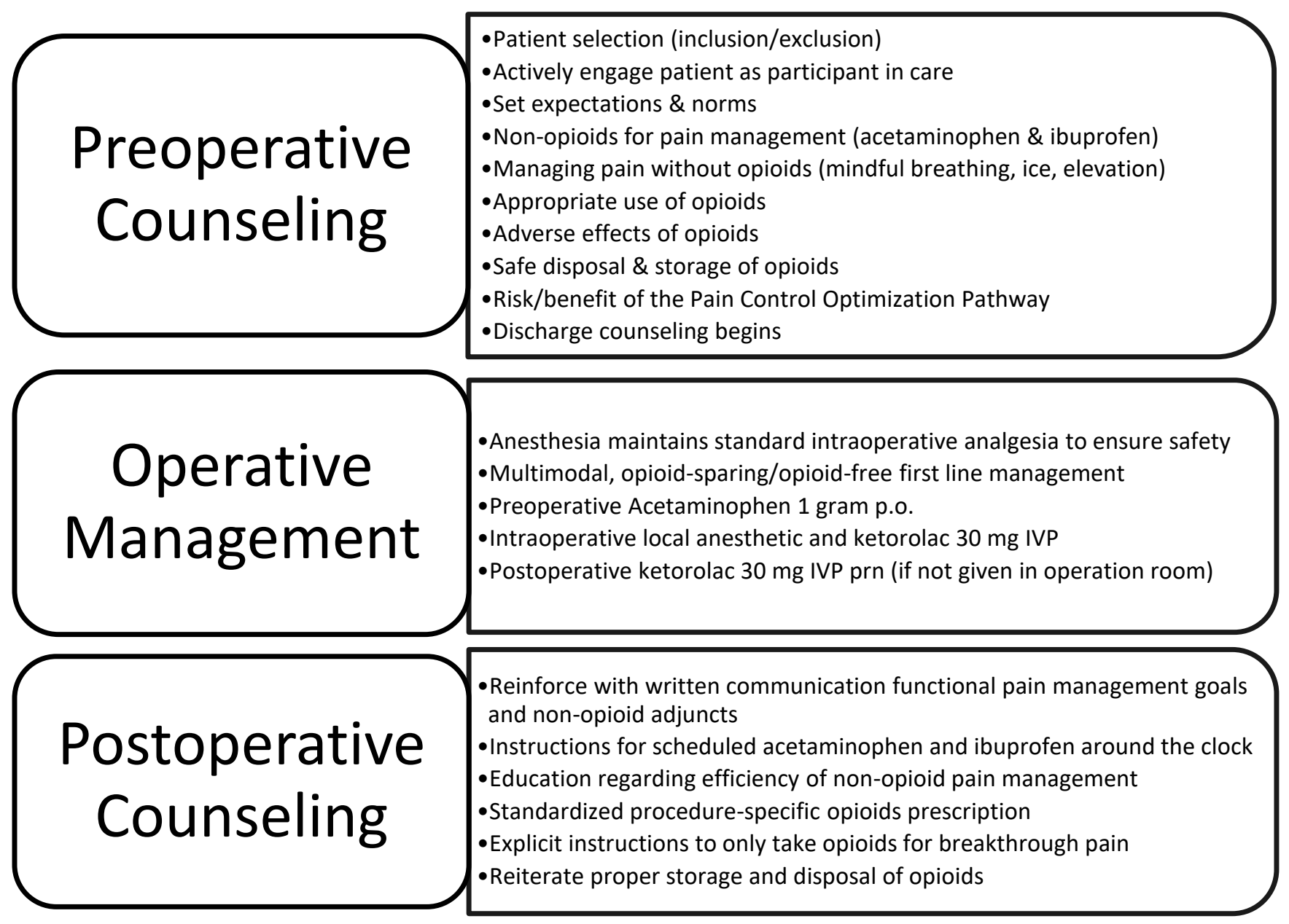

Note. Adapted from "Best Practices," by the Opioid Prescribing Engagement Network (OPEN),

2020 (https://michigan-open.org/). Copyright 2020 by The Regents of the University of

Michigan. 


\section{Figure 3}

\section{SWOT Analysis}

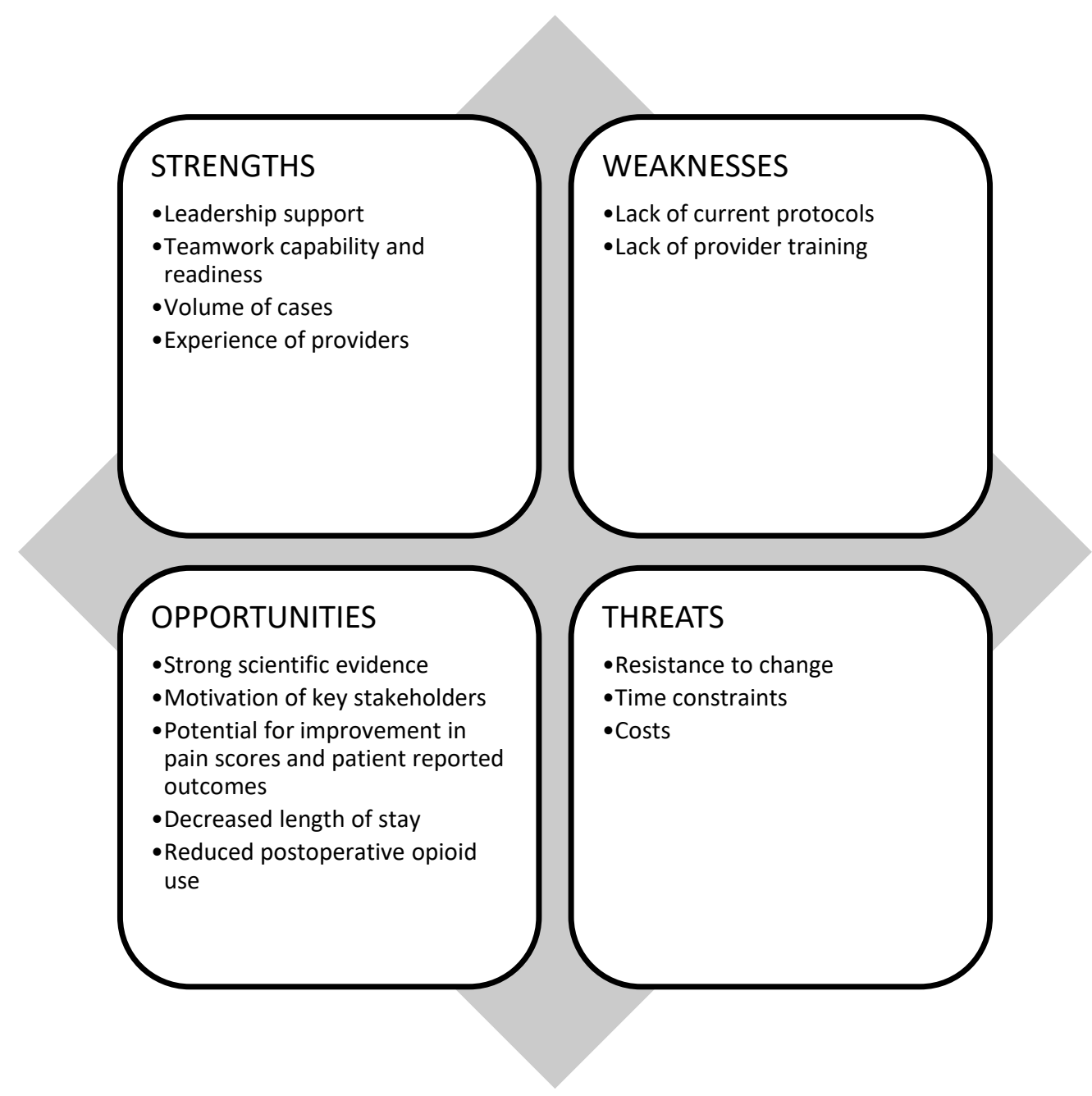




\section{Figure 4}

Numerical Rating Scale

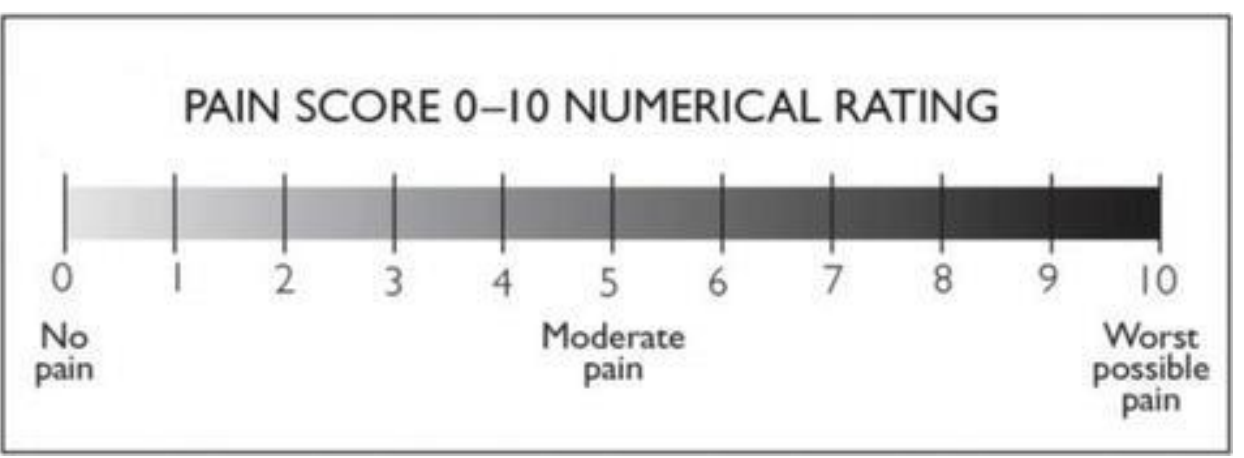

Note. Adapted from "Acute Pain Management in Intensive Care Patients: Facts and Figures," by

Shaikh, N. et al., 2018 (https://www.intechopen.com/books/pain-management-in-special-

circumstances/acute-pain-management-in-intensive-care-patients-facts-and-figures/). Copyright 2018 by IntechOpen. 
PAIN CONTROL OPTIMIZATION PATHWAY

Figure 5

Pain Score at Discharge Versus 72-Hours

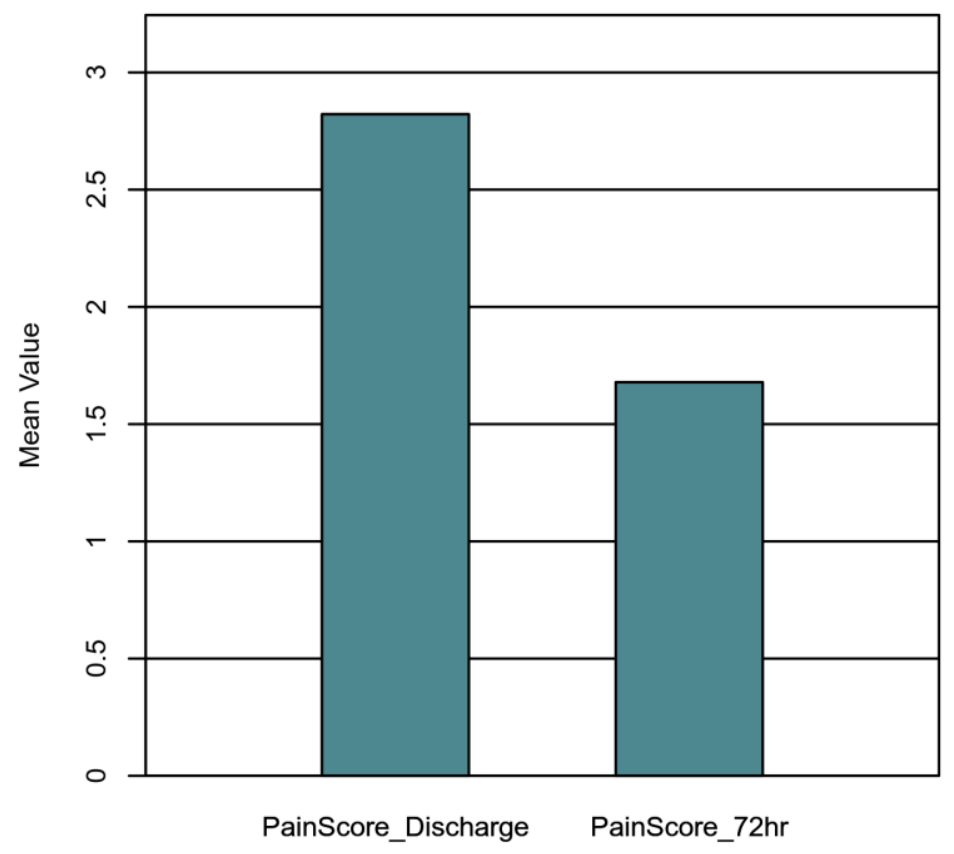




\section{Appendix A}

\section{Summary of Primary Research Evidence}

\begin{tabular}{|c|c|c|c|c|c|}
\hline Citation & $\begin{array}{c}\text { Design, } \\
\text { Level, } \\
\text { Quality } \\
\text { Grade }\end{array}$ & Sample & $\begin{array}{l}\text { Intervention } \\
\text { Comparison }\end{array}$ & Outcome Definition & $\begin{array}{l}\text { Usefulness/ } \\
\text { Results/ } \\
\text { Key Findings }\end{array}$ \\
\hline $\begin{array}{l}\text { Brandal, D., Keller, M. } \\
\text { S., Lee, C., Grogan, T., } \\
\text { Fujimoto, Y., Gricout, } \\
\text { Y., Yamada, T., } \\
\text { Rahman, S., Hofer, I., } \\
\text { Kazanijian, K., Sack, } \\
\text { J., Mahajan, A., Lin, } \\
\text { A., \& Cannesson, M. } \\
\text { (2017). Impact of } \\
\text { enhanced recovery } \\
\text { after surgery and } \\
\text { opioid-free anesthesia } \\
\text { on opioid prescriptions } \\
\text { at discharge from the } \\
\text { hospital: A historical- } \\
\text { prospective study. } \\
\text { Anesthesia \& } \\
\text { Analgesia, 125(5), } \\
1784-1792 . \\
\text { https://doi.org/10.1213/ } \\
\text { ANE.00000000000025 } \\
\underline{10}\end{array}$ & $\begin{array}{l}\text { Design: } \\
\text { Retrospective } \\
\text { cohort } \\
\text { Level: } 3 \\
\text { Quality } \\
\text { Grade: B }\end{array}$ & $\begin{array}{l}\text { Sample: } \\
\text { Pre- } \\
\text { intervention } \\
\text { period: } 194 \\
\text { patients } \\
\text { Post- } \\
\text { intervention } \\
\text { period: } 189 \\
\text { patients } \\
\text { undergoing } \\
\text { colorectal } \\
\text { surgery }\end{array}$ & $\begin{array}{l}\text { Intervention: } \\
\text { Opioid-free and } \\
\text { multimodal } \\
\text { ERAS protocol } \\
\text { Comparison: } \\
\text { Standard care }\end{array}$ & $\begin{array}{l}\text { The presence of opioid } \\
\text { prescription at discharge } \\
\text { define by "yes or no" } \\
\text { The highest and lowest } \\
\text { pain scores in PACU } \\
\text { defined as 0-4 (mild) \& 5- } \\
10 \text { (high) } \\
\text { Total morphine equivalents } \\
\text { defined as 0-4 (below- } \\
\text { median) \& }>4 \text { (above the } \\
\text { median) } \\
\text { Postoperative methadone } \\
\text { consumption defined by } \\
\text { "yes or no" } \\
\text { Highest and lowest pain } \\
\text { scores in } 24 \text { hours before } \\
\text { discharge }\end{array}$ & $\begin{array}{l}\text { - Utilization of opioid-free anesthesia } \\
\text { increased from 17\% (pre-ERAS) to } \\
58 \% \text { (post-ERAS) } \\
\text { ERAS decreased opioid } \\
\text { prescriptions at discharge from } 85 \% \\
\text { to } 78 \% \text { (difference }-7 \%, 95 \% \text { CI - } \\
15 \% \text { to } 1 \% \text { ) and not statistically } \\
\text { significant (p=0.067) } \\
\text { Post-ERAS intraoperative morphine } \\
\text { equivalents decreased by an average } \\
\text { of } 11.4 \text { units (95\% CI, }-1.44 \text { to - } \\
\text { 0.46, p=<0.001) } \\
\text { Despite the decrease in pain scores, } \\
\text { use of opioid-free anesthesia, and no } \\
\text { preoperative opioid use, post-ERAS } \\
\text { prescription opioid use did not } \\
\text { decrease significantly, showing the } \\
\text { need for education on prescribing } \\
\text { practices }\end{array}$ \\
\hline $\begin{array}{l}\text { Chapman, J. S., Roddy, } \\
\text { E., Ueda, S., Brooks, } \\
\text { R., Chen, L. L., \& } \\
\text { Chen, L. M. (2016). }\end{array}$ & $\begin{array}{l}\text { Design: } \\
\text { Retrospective } \\
\text { case-control } \\
\text { study }\end{array}$ & $\begin{array}{l}\text { Sample: } \\
165 \text { patients } \\
\text { undergoing } \\
\text { minimally }\end{array}$ & $\begin{array}{l}\text { Intervention: } \\
\text { ERAS pathway } \\
\text { with patient } \\
\text { education, }\end{array}$ & $\begin{array}{l}\text { LOS defined as mean days } \\
\text { Hospital discharges before } \\
\text { noon defined in several }\end{array}$ & $\begin{array}{l}\text { ERAS patients had decreased LOS } \\
(91 \% \text { discharged POD1 vs. } 60 \% \\
\mathrm{p}<0.001)\end{array}$ \\
\hline
\end{tabular}




\begin{tabular}{|c|c|c|c|c|c|}
\hline 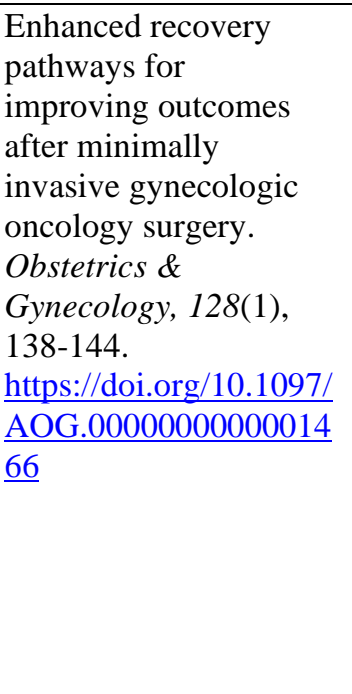 & $\begin{array}{l}\text { Level: } 3 \\
\text { Grade } \\
\text { Quality: B }\end{array}$ & $\begin{array}{l}\text { invasive } \\
\text { gynecologic } \\
\text { oncology } \\
\text { surgery (55 } \\
\text { ERAS) }\end{array}$ & $\begin{array}{l}\text { multimodal } \\
\text { analgesia, opioid } \\
\text { minimization, } \\
\text { nausea } \\
\text { prophylaxis } \\
\text { Comparison: } \\
\text { Standard care }\end{array}$ & $\begin{array}{l}\text { patients and presented as a } \\
\text { percentage } \\
\text { Postoperative pain score } \\
\text { defined on a } 10 \text {-point scale } \\
\text { ( } 0=\text { no pain \& } 10=\text { worst } \\
\text { pain) and described as } \\
\text { mean numbers } \\
\text { Opioid use defined as } \\
\text { morphine equivalents } \\
\text { (conversions not given) } \\
\text { and presented in mg } \\
\text { Hospital costs defined as } \\
\text { mean costs per patient and } \\
\text { described in dollar value }\end{array}$ & $\begin{array}{l}\text { ERAS patients had increased } \\
\text { discharge by noon ( } 15 \% \text { vs. } 4 \%, \\
\text { p=0.03) } \\
\text { ERAS patients had decreased pain } \\
\text { scores }(2.6 \text { vs. } 3 / 12, p=0.03) \\
\text { ERAS patients had } 30 \% \text { fewer } \\
\text { opioids } \\
\text { ERAS patients had decreased } \\
\text { average costs }(\$ 13,771 \text { vs. } \$ 15,649, \\
\text { p=0.01) }\end{array}$ \\
\hline $\begin{array}{l}\text { Echeverria-Villalobos, } \\
\text { M., Stoicea, N., } \\
\text { Todeschini, A. B., } \\
\text { Fiorda-Diaz, J., Uribe, } \\
\text { A. A., Weaver, T., \& } \\
\text { Bergese, S. D. (2019). } \\
\text { Enhanced recovery } \\
\text { after surgery (ERAS): } \\
\text { A prospective review } \\
\text { of postoperative pain } \\
\text { management under } \\
\text { ERAS pathways and its } \\
\text { role on opioid crisis in } \\
\text { the United States. } \\
\text { Clinical Journal of } \\
\text { Pain, 36(3). } \\
\text { https://doi.org/10.1097/ } \\
\text { AJP.000000000000079 } \\
\underline{2}\end{array}$ & $\begin{array}{l}\text { Design: } \\
\text { Literature } \\
\text { review } \\
\text { Level: } 5 \\
\text { Quality } \\
\text { Grade: B }\end{array}$ & $\begin{array}{l}\text { Sample: } \\
\text { PUBMED and } \\
\text { Embase for } \\
\text { keywords: } \\
\text { "postoperative } \\
\text { pain," } \\
\text { "postoperative } \\
\text { pain } \\
\text { management," } \\
\text { "multimodal } \\
\text { analgesia," } \\
\text { "ERAS," } \\
\text { "Enhanced } \\
\text { Recovery" } \\
\text { "opioid-free } \\
\text { analgesia," or } \\
\text { "opioid crisis" }\end{array}$ & $\begin{array}{l}\text { Intervention: } \\
\text { ERAS protocol } \\
\text { Comparison: } \\
\text { Standard care }\end{array}$ & $\begin{array}{l}\text { Postoperative opioid } \\
\text { consumption } \\
\text { Long-term opioid use }\end{array}$ & $\begin{array}{l}\text { - Multimodal, opioid-free analgesia } \\
\text { with ERAS pathway offered optimal } \\
\text { postoperative analgesia, fewer } \\
\text { adverse events, and enhanced } \\
\text { patient satisfaction } \\
\text { Evidence suggested chronic post- } \\
\text { surgical pain may be decreased or } \\
\text { prevented by perioperative, } \\
\text { multimodal analgesia } \\
\text { Evidence suggested short-term } \\
\text { exposure to opioids (surgery) may } \\
\text { lead to long-term use }\end{array}$ \\
\hline $\begin{array}{l}\text { Esteban, F., Cerdan, F. } \\
\text { J., Garcia-Alonso, M., } \\
\text { Sanz-Lopez, R., }\end{array}$ & $\begin{array}{l}\text { Design: } \\
\text { Retrospective } \\
\text { cohort }\end{array}$ & $\begin{array}{l}\text { Sample: } \\
\text { Prospective } \\
\text { group with }\end{array}$ & $\begin{array}{l}\text { Intervention: FT } \\
\text { and open surgery }\end{array}$ & $\begin{array}{l}\text { LOS defined as median } \\
\text { days }\end{array}$ & $\begin{array}{ll}- & \text { Median LOS for lap + FT was } 5 \\
\text { days } \\
\text { - } & \text { Median LOS for open + FT } 6 \text { days }\end{array}$ \\
\hline
\end{tabular}




\begin{tabular}{|c|c|c|c|c|c|}
\hline $\begin{array}{l}\text { Arroyo, A., Ramirez, J. } \\
\text { M., Moreno, C., } \\
\text { Morales, A., \& } \\
\text { Fuentes, M. (2014). A } \\
\text { multicenter comparison } \\
\text { of a fast track or } \\
\text { conventional } \\
\text { postoperative protocol } \\
\text { following laparoscopic } \\
\text { or open elective } \\
\text { surgery for colorectal } \\
\text { cancer surgery. } \\
\text { Colorectal Disease, } \\
\text { 16(2), 134-140. } \\
\text { https://doi.org/10.1111/ } \\
\text { codi.12472 }\end{array}$ & $\begin{array}{l}\text { Level:3 } \\
\text { Grade } \\
\text { Quality: B }\end{array}$ & $\begin{array}{l}300 \text { patients } \\
\text { having elective } \\
\text { colorectal } \\
\text { resection for } \\
\text { cancer } \\
\text { Retrospective } \\
\text { group 201 } \\
\text { patients- same } \\
\text { characteristics }\end{array}$ & $\begin{array}{l}\text { FT and lap } \\
\text { surgery } \\
\text { Comparison: } \\
\text { CC and open } \\
\text { surgery and } \\
\text { CC and lap } \\
\text { surgery }\end{array}$ & $\begin{array}{l}\text { Morbidity defined as the } \\
\text { number of events and } \\
\text { presented as a percentage }\end{array}$ & 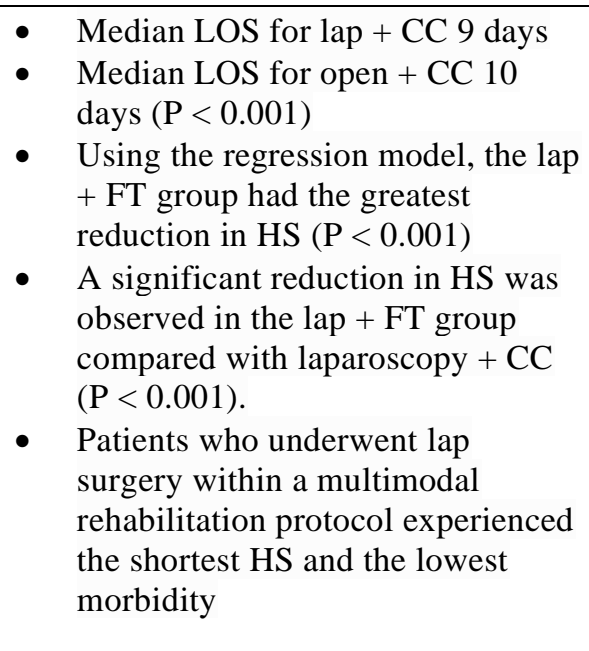 \\
\hline $\begin{array}{l}\text { Hah, J. M., Bateman, } \\
\text { B. T., Ratliff, J., } \\
\text { Curtin, C., \& Sun, E. } \\
\text { (2017). Chronic opioid } \\
\text { use after } \\
\text { surgery: Implications } \\
\text { for perioperative } \\
\text { management in the face } \\
\text { of the opioid epidemic. } \\
\text { Anesthesia \& } \\
\text { Analgesia, 125(5), } \\
\text { 1733-1740. } \\
\text { https://doi.org/10.1213/ } \\
\underline{\text { ANE.00000000000024 }} \\
\underline{8}\end{array}$ & $\begin{array}{l}\text { Design: } \\
\text { Narrative } \\
\text { review } \\
\text { Level: } 5 \\
\text { Quality } \\
\text { Grade: B }\end{array}$ & NA & NA & NA & $\begin{array}{l}\text { - Surgical patients present a challenge } \\
\text { to optimize pain management and } \\
\text { limit opioid use postoperatively } \\
\text { - Interprofessional collaboration must } \\
\text { be involved in clinical and systems- } \\
\text { based interventions to control acute } \\
\text { pain } \\
\text { - Opioids have well documented side } \\
\text { effects, including persistent or } \\
\text { chronic use } \\
\text { - Multimodal strategies should be } \\
\text { considered, including } \\
\text { regional/neuraxial, IV local } \\
\text { anesthetics, and non-opioids } \\
\text { Evidence shows long-term opioid } \\
\text { use after surgery is a risk for opioid- } \\
\text { naïve patients } \\
\text { Opioid-sparing strategies effective } \\
\text { Evidence-based strategies advocated }\end{array}$ \\
\hline $\begin{array}{l}\text { Hallway, A., Vu, J., } \\
\text { Lee, L., Palazzolo, W., } \\
\text { Waljee, J., Brummett, }\end{array}$ & $\begin{array}{l}\text { Design: } \\
\text { Cohort study }\end{array}$ & $\begin{array}{l}\text { Sample: } 190 \\
\text { opioid-naïve } \\
\text { patients } \\
\text { undergoing lap }\end{array}$ & $\begin{array}{l}\text { Intervention: } \\
\text { Opioid-sparing } \\
\text { pain } \\
\text { management }\end{array}$ & $\begin{array}{l}\text { Prescription size } \\
\text { oxycodone } 5 \mathrm{mg} \text { (or } \\
\text { equivalent) were } 4 \text { pills for } \\
\text { lap cholecystectomy, } 10\end{array}$ & $\begin{array}{l}\text { Opioid-sparing postoperative } \\
\text { pathway showed high satisfaction, } \\
\text { optimal pain control, and minimal } \\
\text { or no opioid use after minor surgery }\end{array}$ \\
\hline
\end{tabular}




\begin{tabular}{|c|c|c|c|c|c|}
\hline $\begin{array}{l}\text { C., Englesbe, M., \& } \\
\text { Howard, R. (2019). } \\
\text { Patient Satisfaction and } \\
\text { pain control using an } \\
\text { opioid-sparing } \\
\text { postoperative pathway. } \\
\text { Journal of the } \\
\text { American College of } \\
\text { Surgeons, 229(3), 316- } \\
322 . \\
\text { https://doi.org/10.1016/ } \\
\text { j.jamcollsurg.2019.04.0 } \\
\underline{\underline{0}}\end{array}$ & $\begin{array}{l}\text { Level: } 3 \\
\text { Quality } \\
\text { Grade: B }\end{array}$ & $\begin{array}{l}\text { chole- } \\
\text { cystectomy, } \\
\text { lap inguinal } \\
\text { hernia repair, } \\
\text { thyroidectomy/ } \\
\text { parathyroid- } \\
\text { ectomy, } \\
\text { robotic } \\
\text { prostatectomy, } \\
\text { endoscopic } \\
\text { sinus } \\
\text { operation, or } \\
\text { lap sleeve } \\
\text { gastrectomy }\end{array}$ & $\begin{array}{l}\text { pathway } \\
\text { Comparison: } \\
\text { Standard care }\end{array}$ & $\begin{array}{l}\text { pills for lap inguinal hernia } \\
\text { repair, } 5 \text { pills for } \\
\text { thyroidectomy/parathyroid } \\
\text { ectomy, } 6 \text { pills for robotic } \\
\text { prostatectomy, } 8 \text { pills for } \\
\text { sinus operation, and } 10 \\
\text { pills for lap sleeve } \\
\text { gastrectomy presented as } \\
\text { means } \\
\text { Pain score after } 1 \text { week ( } 0= \\
\text { no pain, } 1=\text { minimal pain, } \\
2=\text { moderate pain, } 3= \\
\text { severe pain) } \\
\text { Pain score at time of } \\
\text { surgery ( } 1=\text { no pain to } 10= \\
\text { worst pain imaginable) } \\
\text { Satisfaction score (1= } \\
\text { extremely dissatisfied to } \\
10=\text { extremely satisfied) } \\
\text { Quality of life after } \\
\text { procedure (1= worst } \\
\text { quality of life to } 5=\text { best } \\
\text { quality of life) } \\
\text { Regret for undergoing } \\
\text { surgery ( } 1=\text { strongly regret } \\
\text { to } 5=\text { no regret) } \\
\text { Percent recovered at time } \\
\text { of survey ( } 0 \text { to } 100 \%) \\
\text { Asked if used } \\
\text { acetaminophen/ibuprofen } \\
\text { (yes/no) and if they agreed } \\
\text { (yes/no) pain was } \\
\text { manageable }\end{array}$ & $\begin{array}{l}\text { among opioid-naïve patients at } 30 \\
\text { and } 90 \text { days } \\
\text { - Opioid-sparing pathway median } \\
\text { prescription rescue size was } 5 \text { (IQR } \\
\text { 4-6) pills for } 152 \text { ( } 82 \% \text { of patients) } \\
\text { - } \text { Opioid-sparing pathway median } \\
\text { opioid use for whole cohort was } 0 \\
\text { (IQR 0-4) } \\
\text { - } 52 \% \text { opioid-sparing had no opioids } \\
\text { - } 98 \% \text { opioid-sparing had } 10 \text { or less } \\
\text { pills (average } 4 \text { pills) } \\
\text { Opioid-sparing pathway median } \\
\text { left-over pills was } 2 \text { and } 3 \text { patients } \\
\text { requested refills } \\
\text { Opioid-sparing pathway } 62 \% \text { used } \\
\text { both acetaminophen \& Ibuprofen, } \\
\text { 88\% used one, 12\% used neither } \\
\text { Chronic opioid users had higher } \\
\text { pain scores compared to opioid- } \\
\text { naïve (2 [IQR1-2] vs. } 1 \text { [IQR 1-2], } \\
\text { p=0.014) and received larger rescue } \\
\text { prescriptions (6+/-3 vs. 4+/-4, } \\
\text { p=0.0003) }\end{array}$ \\
\hline
\end{tabular}




\begin{tabular}{|c|c|c|c|c|c|}
\hline $\begin{array}{l}\text { Harryman, C., Plymale, } \\
\text { M. A., Stearns, E., } \\
\text { Davenport, D. L, } \\
\text { Chang, W., \& Roth, J. } \\
\text { S. (2019). Enhanced } \\
\text { value with } \\
\text { implementation of } \\
\text { ERAS protocol for } \\
\text { ventral hernia repair. } \\
\text { Surgical Endoscopy, } \\
\text { 10(1). } \\
\text { https://doi.org/10.1007/ } \\
\text { s00464-019-07166-2 }\end{array}$ & $\begin{array}{l}\text { Design: } \\
\text { Cohort study } \\
\text { Level: } 3 \\
\text { Quality } \\
\text { Grade: B }\end{array}$ & $\begin{array}{l}\text { Sample: } 178 \\
\text { patients } \\
\text { undergoing } \\
\text { open VHR } \\
\text { operations } \\
\text { (127 pre- } \\
\text { ERAS, 51- } \\
\text { post-ERAS) }\end{array}$ & $\begin{array}{l}\text { Intervention: } \\
\text { ERAS protocol } \\
\text { for VHR with } \\
\text { preoperative } \\
\text { counseling, } \\
\text { preoperative } \\
\text { preparation, } \\
\text { perioperative } \\
\text { (multimodal pain } \\
\text { management \& } \\
\text { fluid } \\
\text { management), } \\
\text { and early } \\
\text { mobilization key } \\
\text { elements } \\
\text { Comparison: } \\
\text { Standard care }\end{array}$ & $\begin{array}{l}\text { LOS defined as median } \\
\text { days } \\
\text { Return to bowel function } \\
\text { defined as median days } \\
\text { Surgical site occurrences } \\
\text { defined as superficial or } \\
\text { deep SSI, infected seroma, } \\
\text { seroma requiring drainage } \\
\text { described in percentage } \\
\begin{array}{l}\text { Non-wound complications } \\
\text { presented in percentage }\end{array} \\
\text { 30-day readmission in } \\
\text { percentage }\end{array}$ & $\begin{array}{ll}\text { - } & \text { ERAS reduced overall surgical site } \\
\text { occurrence from } 33 \% \text { to } 16 \% \\
\text { - } \\
\text { ERAS reduced LOS from } 5 \text { to } 4 \\
\text { days } \\
\text { - } \\
\text { ERAS reduced time to bowel } \\
\text { function from } 4 \text { to } 3 \text { days }(\mathrm{p}<0.001) \\
\text { - } \begin{array}{l}\text { ERAS decreased overall cost of } \\
\text { hospitalization from an average of }\end{array} \\
\$ 15,151 \text { to } \$ 14,692 \\
\text { - } \\
\text { ERAS reduced } 30 \text {-day readmission } \\
\text { rate from } 19 \% \text { to } 6 \%\end{array}$ \\
\hline $\begin{array}{l}\text { Kalogera, E. \& Dowdy, } \\
\text { S. C. (2019). Enhanced } \\
\text { recovery after surgery } \\
\text { and acute postoperative } \\
\text { pain management. } \\
\text { Clinical Obstetrics and } \\
\text { Gynecology, 62(4), } \\
\text { 656-665. } \\
\text { https://doi.org/10.1097/ } \\
\underline{\text { GRF.0000000000004 }} \\
\underline{5}\end{array}$ & $\begin{array}{l}\text { Design: } \\
\text { Review } \\
\text { Level: } 5 \\
\text { Quality } \\
\text { Grade: C }\end{array}$ & Sample: NA & $\begin{array}{l}\text { Intervention: } \\
\text { ERAS protocol } \\
\text { Comparison: } \\
\text { Standard care }\end{array}$ & $\begin{array}{l}\text { Preoperative counseling } \\
\text { and pre-habilitation } \\
\text { Nutritional optimization } \\
\text { Perioperative multimodal } \\
\text { analgesia (preemptive, } \\
\text { postoperative pain } \\
\text { management, regional } \\
\text { analgesia) } \\
\text { Postoperative prescriptions }\end{array}$ & 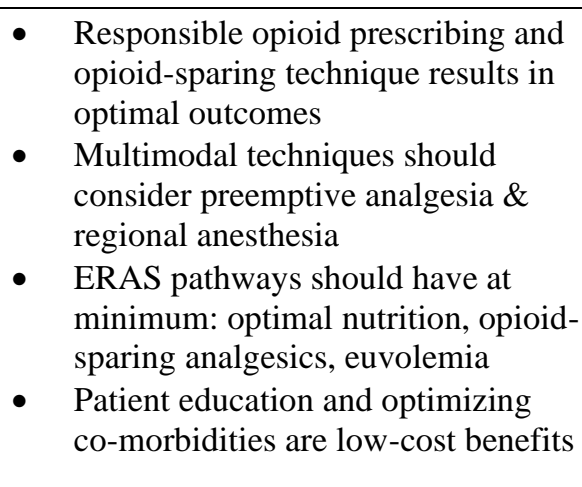 \\
\hline
\end{tabular}




\begin{tabular}{|c|c|c|c|c|c|}
\hline $\begin{array}{l}\text { Kennedy, R. H., } \\
\text { Francis, E. A., } \\
\text { Wharton, R., Blazeby, } \\
\text { J. M., Quirke, P., West, } \\
\text { N. P., \& Dutton, S. J. } \\
\text { (2014). Multicenter } \\
\text { randomized controlled } \\
\text { trial of conventional } \\
\text { versus laparoscopic } \\
\text { surgery for colorectal } \\
\text { cancer within an } \\
\text { enhanced recovery } \\
\text { programme: EnROL. } \\
\text { Journal of Clinical } \\
\text { Oncology, 32(17), } \\
\text { 1804-1811. } \\
\text { https://doi.org/10.1200/ } \\
\text { JCO.2013.54.3694 }\end{array}$ & $\begin{array}{l}\text { Design: } \\
\text { High-quality, } \\
\text { multicenter, } \\
\text { randomized } \\
\text { control trial } \\
\text { Level: } 1 \\
\text { Quality } \\
\text { Grade: A }\end{array}$ & $\begin{array}{l}\text { Sample: } \\
204 \text { patients } \\
\text { (laparoscopy, } \\
\mathrm{n}=103 ; \text { open } \\
\text { surgery, } \\
\mathrm{n}=101 \text { ) were } \\
\text { recruited from } \\
12 \text { centers }\end{array}$ & $\begin{array}{l}\text { Intervention: } \\
\text { Laparoscopic } \\
\text { colorectal } \\
\text { surgery within an } \\
\text { ERP including } \\
\text { preoperative, } \\
\text { perioperative, } \\
\text { intraoperative \& } \\
\text { postoperative } \\
\text { variables } \\
\text { Comparison: } \\
\text { Open colorectal } \\
\text { surgery with an } \\
\text { ERP }\end{array}$ & $\begin{array}{l}\text { PRO of physical fatigue } \\
\text { measured by MFI- } 20 \text { at } \\
\text { baseline and 1-month } \\
\text { postoperative and } \\
\text { presented as adjusted mean } \\
\text { scores } \\
\text { Subscales: general fatigue, } \\
\text { activity, motivation, mental } \\
\text { fatigue } \\
\text { SF-36 physical health } \\
\text { presented as adjusted } \\
\text { means. Subscales: physical } \\
\text { functioning, role, body } \\
\text { pain, general health } \\
\text { SF-36 mental health } \\
\text { presented as adjusted } \\
\text { means. Subscales: vitality, } \\
\text { social functioning, role, } \\
\text { mental health } \\
\text { LOS defined as mean } \\
\text { length of primary } \\
\text { hospitalization and median } \\
\text { total length of hospital stay } \\
\text { (including readmission up } \\
\text { to } 30 \text { days) } \\
\text { Complications defined as } \\
\text { surgical, cardiorespiratory } \\
\text { and injection complications } \\
\text { within } 30 \text { days }\end{array}$ & $\begin{array}{l}\text { ERP with open and laparoscopic } \\
\text { surgery showed similar scores in } \\
\text { fatigue (mean laparoscopy: } 12.2 \text { and } \\
\text { mean open: } 12.1 \text {, adjusted mean - } \\
\text { 0.6, p=0.93) } \\
\text { No statistically significant } \\
\text { difference between SF-36 physical } \\
\text { and mental health } \\
\text { ERP with lap surgery significantly } \\
\text { reduced LOS (mean lap } 5 \text { days, IQR } \\
4 \text { to } 6 \text { vs. open, } 6 \text { days, IQR } 4 \text { to 9) } \\
\text { No statistically significant } \\
\text { difference in complications between } \\
\text { cohorts }\end{array}$ \\
\hline $\begin{array}{l}\text { Kumar, K., Kirksey, M. } \\
\text { A., Duong, S., \& Wu, } \\
\text { C. L. (2017). A review } \\
\text { of opioid-sparing } \\
\text { modalities in } \\
\text { perioperative pain }\end{array}$ & $\begin{array}{l}\text { Design: } \\
\text { Narrative } \\
\text { review }\end{array}$ & NA & NA & NA & $\begin{array}{l}\text { - Surgical patients present a challenge } \\
\text { to manage acute pain and minimize } \\
\text { the risk of long-term opioid use } \\
\text { Risks associated with opioid use } \\
\text { after surgery include tolerance, } \\
\text { physical dependence, hyperalgesia, }\end{array}$ \\
\hline
\end{tabular}




\begin{tabular}{|c|c|c|c|c|c|}
\hline $\begin{array}{l}\text { management: Methods } \\
\text { to decrease opioid use } \\
\text { postoperatively. } \\
\text { Anesthesia and } \\
\text { Analgesia, } 125(5), \\
\text { 1749-1760. } \\
\text { https://doi.org/10.1213/ } \\
\text { ANE.00000000000024 } \\
97\end{array}$ & $\begin{array}{l}\text { Quality } \\
\text { Grade: B }\end{array}$ & & & & $\begin{array}{l}\text { adverse effects (sedation, } \\
\text { respiratory depression, ileus, } \\
\text { delirium), misuse, abuse, addiction, } \\
\text { diversion } \\
\text { - Surgery is a stimulus for long-term } \\
\text { use } \\
\text { Prescribing opioids at discharge to } \\
\text { opioid-naïve patients is a risk factor } \\
\text { for chronic use (adjusted OR, 4.9; } \\
\text { 95\% CI 3.22-7.45) } \\
\text { Predictors of chronic use after } \\
\text { surgery include preoperative use, } \\
\text { socioeconomic status, pre-operative } \\
\text { pain, comorbidities, drug, alcohol } \\
\text { or, tobacco use } \\
\text { Strategies to provide opioid-sparing } \\
\text { acute postoperative pain control } \\
\text { include multimodal analgesia, } \\
\text { regional anesthesia, intravenous } \\
\text { local anesthesia, and non-opioid } \\
\text { medication }\end{array}$ \\
\hline $\begin{array}{l}\text { Li, J., Kong, X. X., } \\
\text { Zhou, J. J., Song, Y. } \\
\text { M., Huang, X. F., Li, } \\
\text { G. H., Ying, X. J., Dai, } \\
\text { X. Y., Lu, M., Jiang, } \\
\text { K., Fu, D. L., Li, X. L., } \\
\text { He, J. J., Want, J. W., } \\
\text { Sun, L. F., Xu, D., Xu, } \\
\text { J. Y., Chen, M., Tian, } \\
\text { Y., Li, J. S., Yan, M., } \\
\text { Yuan, Y., \& Ding, K. } \\
\text { F. (2019). Fast-track } \\
\text { multidisciplinary } \\
\text { treatment versus } \\
\text { conventional treatment } \\
\text { for colorectal cancer: A } \\
\text { multicenter, open-label } \\
\text { randomized controlled }\end{array}$ & $\begin{array}{l}\text { Design: } \\
\text { Multicenter, } \\
\text { prospective } \\
\text { RCT } \\
\text { Level: } 1 \\
\text { Grade } \\
\text { Quality: A }\end{array}$ & $\begin{array}{l}\text { Sample: } \\
342 \text { patients } \\
\text { with colorectal } \\
\text { cancer } \\
\text { randomly } \\
\text { assigned to } 2 \\
\text { groups }\end{array}$ & $\begin{array}{l}\text { Intervention: } \\
\text { FTMDT } \\
\text { Comparison: } \\
\text { Conventional } \\
\text { treatment }\end{array}$ & $\begin{array}{l}\text { LOS in defined in median } \\
\text { days } \\
\text { Quality of life defined by } \\
\text { EORTC QLQ-C30 5-item } \\
\text { survey (physical, role, } \\
\text { social, emotional, cognitive } \\
\text { function) \& } 9 \text { single items } \\
\text { (pain, fatigue, financial } \\
\text { impact, appetite loss, } \\
\text { nausea and vomiting, } \\
\text { diarrhea, constipation) } \\
\text { Cost defined by overall } \\
\text { cost of hospitalization in } \\
\text { dollars }\end{array}$ & 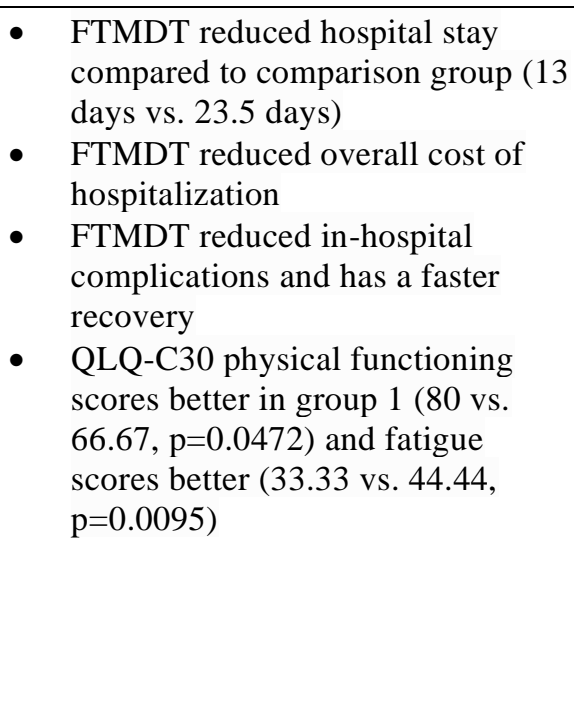 \\
\hline
\end{tabular}




\begin{tabular}{|c|c|c|c|c|c|}
\hline $\begin{array}{l}\text { study. BMC Cancer, } \\
\text { 19(1). } \\
\text { https://doi.org/10.1186/ } \\
\text { s12885-019-6188-x }\end{array}$ & & & & & \\
\hline $\begin{array}{l}\text { Majumder, A., } \\
\text { Fayezizadeh, M., } \\
\text { Neupane, R., Elliott, H. } \\
\text { L., \& Novitsky, Y. W. } \\
\text { (2016). Benefits of } \\
\text { multimodal enhanced } \\
\text { recovery pathway in } \\
\text { patients undergoing } \\
\text { open ventral hernia } \\
\text { repair. Journal of the } \\
\text { American College of } \\
\text { Surgeons, 222(6), } \\
\text { 1106-1115. } \\
\text { https://doi.org/10.1016/ } \\
\text { j.jamcollsurg.2016.02.0 } \\
15\end{array}$ & $\begin{array}{l}\text { Design: } \\
\text { Cohort study } \\
\text { Level: } 3 \\
\text { Quality } \\
\text { Grade: B }\end{array}$ & $\begin{array}{l}\text { Sample: } 200 \\
\text { patients } \\
\text { undergoing } \\
\text { VHR (100 } \\
\text { ERAS group, } \\
100 \text { historical } \\
\text { cohort) }\end{array}$ & $\begin{array}{l}\text { Intervention: } \\
\text { ERAS pathway } \\
\text { for ventral hernia } \\
\text { repair with } \\
\text { preoperative, } \\
\text { perioperative, } \\
\text { intraoperative } \\
\text { (pain control), } \\
\text { postoperative } \\
\text { (pain control), } \\
\text { intestinal and } \\
\text { fluid variables } \\
\text { Comparison: } \\
\text { Ventral hernia } \\
\text { repair prior to } \\
\text { intervention } \\
\text { (standard care) }\end{array}$ & $\begin{array}{l}\text { Time to oral narcotics } \\
\text { defined as time to rescue } \\
\text { narcotics and presented as } \\
\text { mean hours } \\
\text { LOS defined as mean days } \\
\text { Readmission rates defined } \\
\text { as } 30 \text {-day readmission and } \\
\text { presented as percentage } \\
\text { Time to liquid diet defined } \\
\text { POD } 1 \text { as <250ml/shift and } \\
\text { presented as mean hours } \\
\text { Time to regular diet } \\
\text { defined POD } 2 \text { as volume } \\
\text { unrestricted diet presented } \\
\text { as mean hours } \\
\text { Emesis after diet (severe } \\
\text { nausea or emesis) defined } \\
\text { as number of patients and } \\
\text { presented as percentage } \\
\text { Functional recovery } \\
\text { defined as time to bowel } \\
\text { function (flatulence and } \\
\text { bowel movement) } \\
\text { presented in mean days }\end{array}$ & $\begin{array}{l}\text { - } \quad \text { ERAS decreased LOS by } 34 \% \text { (4.0 } \\
\text { vs. } 6.1, \mathrm{p}<0.001) \\
\text { - } \quad \text { ERAS reduced time to oral narcotic } \\
\text { use }(1.4 \text { vs. } 2.6, \mathrm{p}<0.001) \\
\text { - } \quad \text { ERAS improved readmission rates } \\
\text { (4\% vs. } 16 \%, \mathrm{p}=0.008) \\
\text { - } \text { ERAS accelerated intestinal } \\
\text { recovery } \\
\text { Multimodal anesthetic with } \\
\text { decreased IV opioids, use of } \\
\text { preoperative and postoperative } \\
\text { gabapentin, TAP block, } \\
\text { postoperative acetaminophen, and } \\
\text { NSAIDs improved outcomes for } \\
\text { VHR }\end{array}$ \\
\hline
\end{tabular}




\begin{tabular}{|c|c|c|c|c|c|}
\hline 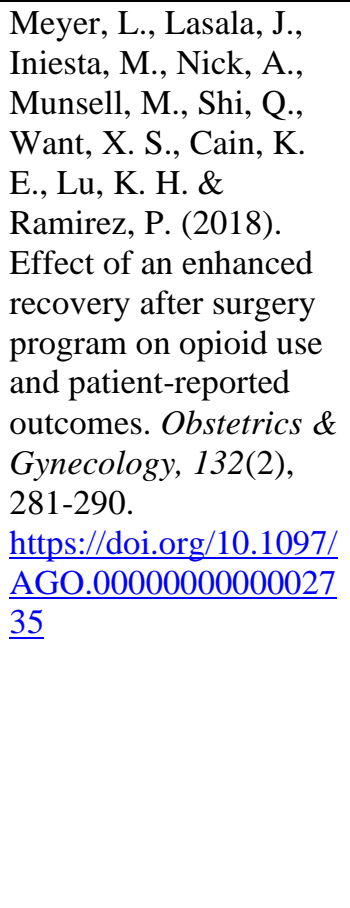 & $\begin{array}{l}\text { Design: } \\
\text { Cohort study } \\
\text { Level: } 3 \\
\text { Quality } \\
\text { Grade: B }\end{array}$ & $\begin{array}{l}\text { Sample: } 607 \\
\text { patients } \\
\text { undergoing } \\
\text { gynecologic } \\
\text { surgery (pre- } \\
\text { ERAS 74, } \\
\text { post-ERAS } \\
533 \text { ) } \\
\text { 293 PROs } \\
\text { obtained }\end{array}$ & $\begin{array}{l}\text { Intervention: } \\
\text { ERAS program } \\
\text { with } \\
\text { preoperative, } \\
\text { intraoperative, } \\
\text { and } \\
\text { postoperative } \\
\text { phases } \\
\text { Comparison: } \\
\text { previous care }\end{array}$ & $\begin{array}{l}\text { Opioid consumption } \\
\text { defined as morphine } \\
\text { equivalents presented as } \\
\text { median } \\
\text { PROs defined by MD } \\
\text { Anderson Symptom } \\
\text { Inventory-Ovarian Cancer } \\
\text { Module ( } 27 \text {-item validated } \\
\text { tool) rated } 0-10 \text { (0=not } \\
\text { present, } 10=\text { as bad as you } \\
\text { can imagine) } \\
\text { Patient-reported pain } \\
\text { described on } 10 \text {-point pain } \\
\text { scale (range } 0-10 \text { ) } \\
\text { LOS defined in mean days } \\
\text { 30-day complication rate } \\
\text { defined by Dindo-Clavien } \\
\text { grading system (grade 1-4) }\end{array}$ & 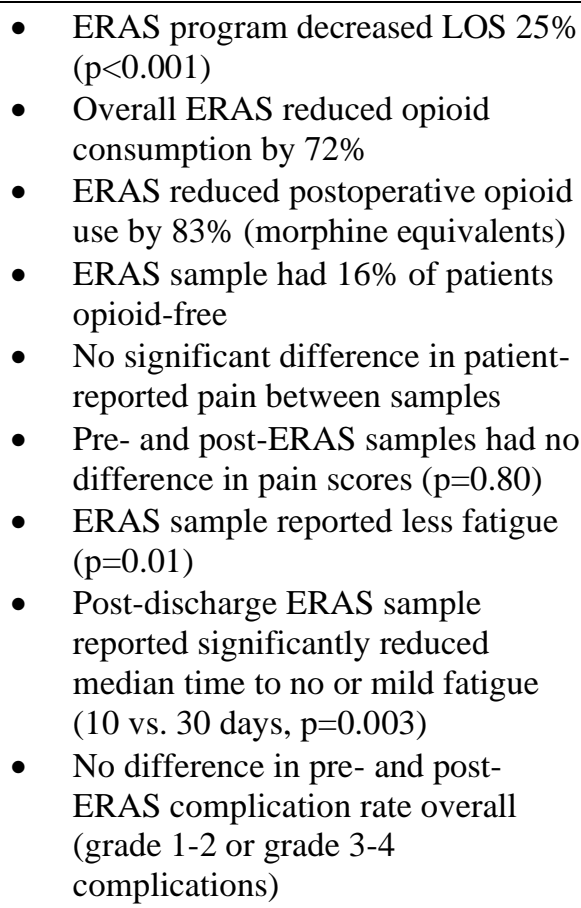 \\
\hline $\begin{array}{l}\text { Nassif, G. J., \& Miller, } \\
\text { T. E. (2018). Evolving } \\
\text { the management of } \\
\text { acute perioperative } \\
\text { pain towards opioid } \\
\text { free protocols: a } \\
\text { narrative review. } \\
\text { Current Medical } \\
\text { Research and Opinion, } \\
\text { 35(12), 2129-2136. } \\
\text { https://doi.org/10.1080/ } \\
\underline{03007995.2019 .164600} \\
\underline{1}\end{array}$ & $\begin{array}{l}\text { Design: } \\
\text { Narrative } \\
\text { review } \\
\text { Level: } 5 \\
\text { Quality } \\
\text { Grade: } \\
\text { B }\end{array}$ & $\begin{array}{l}\text { Sample: Meta- } \\
\text { analysis and } \\
\text { clinical studies } \\
\text { focusing on } \\
\text { comparing } \\
\text { opioid vs. } \\
\text { opioid- } \\
\text { free/sparing } \\
\text { strategies }\end{array}$ & $\begin{array}{l}\text { Intervention: } \\
\text { Opioid- } \\
\text { free/opioid- } \\
\text { sparing strategies } \\
\text { Comparison: } \\
\text { Opioid-intensive } \\
\text { strategy }\end{array}$ & $\begin{array}{l}\text { Pain management } \\
\text { strategies including } \\
\text { multimodal (opioid and } \\
\text { non-opioid, regional and } \\
\text { neuraxial techniques) } \\
\text { Opioid use defined as } \\
\text { morphine and/or fentanyl } \\
\text { and no dose given } \\
\text { Pain scores using validated } \\
\text { tools not defined } \\
\text { Patient satisfaction using } \\
\text { tools not defined }\end{array}$ & $\begin{array}{l}\text { Multimodal analgesia reduced } \\
\text { opioid use by } 15-55 \% 3 \text { meta- } \\
\text { analyses } \\
\text { - Multimodal analgesia with IV } \\
\text { Tylenol improved patient } \\
\text { satisfaction in } 5 \text { RCTs by } 32.3 \% \\
\text { Multimodal analgesia significantly } \\
\text { improved patient pain scores } \\
\text { - Multimodal analgesia decreased } \\
\text { overall costs to healthcare system } \\
\text { specifically related to reducing } \\
\text { adverse events and improved } \\
\text { functional recovery } \\
\text { Opioid-free intraoperative analgesia } \\
\text { showed patient and surgeon } \\
\text { satisfaction along with opioid-fee }\end{array}$ \\
\hline
\end{tabular}




\begin{tabular}{|c|c|c|c|c|c|}
\hline & & & & $\begin{array}{l}\text { Costs defined as overall } \\
\text { cost to healthcare system }\end{array}$ & $\begin{array}{l}\text { patients receiving overall } 75 \% \text { less } \\
\text { opioids during the perioperative } \\
\text { course }\end{array}$ \\
\hline $\begin{array}{l}\text { Soffin, E., Waldman, } \\
\text { S., Stack, R., \& } \\
\text { Liguori, G., A. (2017). } \\
\text { An evidence-based } \\
\text { approach to } \\
\text { the prescription opioid } \\
\text { epidemic in orthopedic } \\
\text { surgery. Anesthesia \& } \\
\text { Analgesia, 125(5), } \\
\text { 1704-1713. } \\
\underline{\text { https://doi.org/10.1213/ }} \text { ANE.00000000000024 } \\
\underline{33}\end{array}$ & $\begin{array}{l}\text { Design: } \\
\text { Narrative } \\
\text { review } \\
\text { Level: } 5 \\
\text { Quality } \\
\text { Grade: B }\end{array}$ & $\begin{array}{l}\text { Sample: } \\
\text { Providers at } \\
\text { Hospital for } \\
\text { Special } \\
\text { Surgery in } \\
\text { New York }\end{array}$ & $\begin{array}{l}\text { Intervention: } \\
\text { Evidence-based } \\
\text { comprehensive } \\
\text { program for } \\
\text { managing } \\
\text { controlled } \\
\text { substance } \\
\text { prescribing } \\
\text { Comparison: NA }\end{array}$ & $\begin{array}{l}\text { Changing prescribing } \\
\text { habits } \\
\text { Managing pain } \\
\text { Educating prescribers and } \\
\text { patients }\end{array}$ & 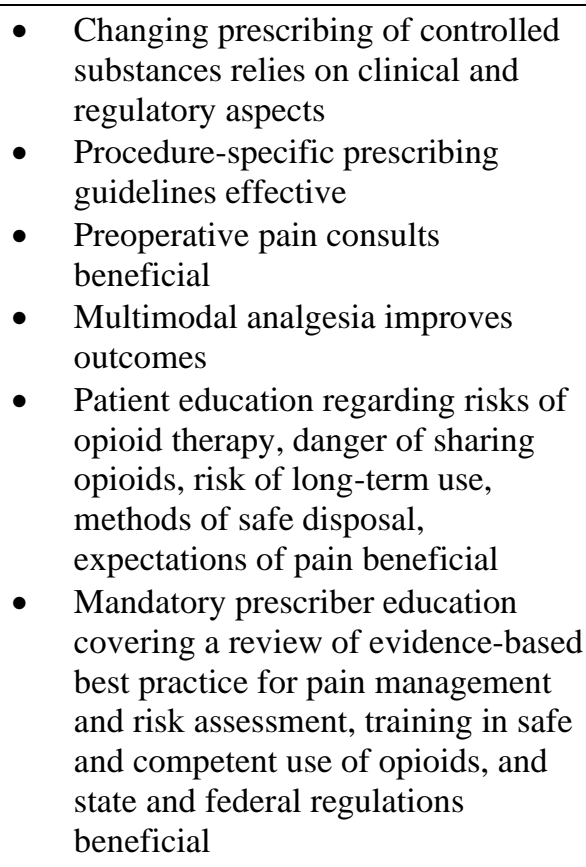 \\
\hline $\begin{array}{l}\text { Stepan, J. G., } \\
\text { Lovecchio, F. C., } \\
\text { Premkumar, A., } \\
\text { Kahlenberg, C. A., } \\
\text { Albert, T., Baurely, J., } \\
\& \\
\text { Nwachukwu, B. } \\
\text { (2019). Development } \\
\text { of an institutional } \\
\text { opioid prescriber } \\
\text { education program and } \\
\text { opioid-prescribing } \\
\text { guidelines: Impact on } \\
\text { prescribing practices. }\end{array}$ & $\begin{array}{l}\text { Design: } \\
\text { Retrospective } \\
\text { cohort study } \\
\text { Level: } 3 \\
\text { Quality } \\
\text { Grade: B }\end{array}$ & $\begin{array}{l}\text { Sample: } \\
\text { Post- } \\
\text { intervention } \\
\text { cohort } 48 \\
\text { patients } \\
\text { undergoing } \\
\text { ambulatory } \\
\text { hand, sports, } \\
\text { and foot and } \\
\text { ankle surgery }\end{array}$ & $\begin{array}{l}\text { Intervention: 1- } \\
\text { hour mandatory } \\
\text { narcotic } \\
\text { prescribing } \\
\text { education } \\
\text { program and } \\
\text { dissemination of } \\
\text { prescribing } \\
\text { guidelines } \\
\text { Comparison: } \\
\text { Pre-intervention } \\
\text { standard care }\end{array}$ & $\begin{array}{l}\text { Opioid pills defined as } \\
\text { morphine equivalents: } 1 \\
\text { table hydrocodone } 5 \mathrm{mg}= \\
5 \text { oral morphine } \\
\text { equivalents, oxycodone } 5 \\
\text { mg }=7.5 \text { oral morphine } \\
\text { equivalents, codeine } 30 \mathrm{mg} \\
=4.5 \text { oral morphine } \\
\text { equivalents, and } \\
\text { hydromorphone } 2 \mathrm{mg}=8 \\
\text { oral morphine equivalents }\end{array}$ & 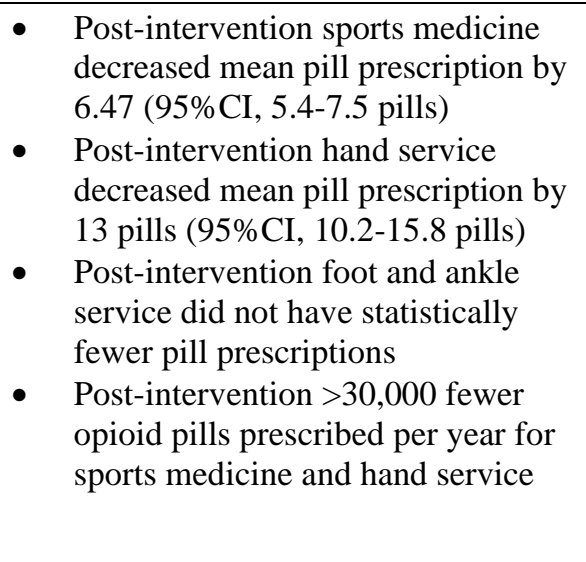 \\
\hline
\end{tabular}




\begin{tabular}{|c|c|c|c|c|c|}
\hline $\begin{array}{l}\text { The Journal of Bone } \\
\text { and Joint Surgery, } \\
\text { 101(1), 5-13. } \\
\text { https://doi.org/10.2106/ } \\
\text { JBJS.17.014645 }\end{array}$ & & & & & $\begin{array}{l}\text { Consensus-based method for } \\
\text { postoperative opioid-prescribing } \\
\text { guidelines and provider education } \\
\text { significantly reduced the quantity of } \\
\text { opioid pills and oral morphine } \\
\text { equivalents prescribed after } \\
\text { ambulatory surgery }\end{array}$ \\
\hline $\begin{array}{l}\text { Trowbridge, E. R., } \\
\text { Evans, S. L., Sarosiek, } \\
\text { B. M., Modesitt, S. C., } \\
\text { Redick, D. L., } \\
\text { Tiouririne, M., \& } \\
\text { Hullfish, K. L. (2019). } \\
\text { Enhanced recovery } \\
\text { program for minimally } \\
\text { invasive and vaginal } \\
\text { urogynecologic } \\
\text { surgery. International } \\
\text { Urogynecology } \\
\text { Journal, 30(2), 313- } \\
\text { 321. } \\
\text { http://doi.org/10.1007/s } \\
\underline{00192-018-3794-0}\end{array}$ & $\begin{array}{l}\text { Design: } \\
\text { Cohort study } \\
\text { Level: } 3 \\
\text { Quality } \\
\text { Grade: B }\end{array}$ & $\begin{array}{l}\text { Sample: } \\
\text { Patients } \\
\text { undergoing } \\
\text { elective } \\
\text { minimally } \\
\text { invasive pelvic } \\
\text { surgery } \\
\text { Sample size: } \\
118 \text { patients } \\
\text { compared to } \\
76 \text { in historical } \\
\text { cohort }\end{array}$ & $\begin{array}{l}\text { Intervention: } \\
\text { ERP included } \\
\text { patient } \\
\text { counseling, } \\
\text { carbohydrate } \\
\text { loading, } \\
\text { avoidance of } \\
\text { opioids, goal- } \\
\text { directed fluid, } \\
\text { immediate } \\
\text { postoperative } \\
\text { feeding, and } \\
\text { early ambulation } \\
\text { Comparison: No } \\
\text { EPR }\end{array}$ & $\begin{array}{l}\text { LOS: admission defined as } \\
\text { time of first preoperative } \\
\text { set of vitals \& } \\
\text { discharge document in } \\
\text { EHR and presented as } \\
\text { mean hours } \\
\text { Hospital discharges before } \\
\text { noon defined in number of } \\
\text { patients and presented as } \\
\text { percentage } \\
\text { Pain scores defined on a 0- } \\
\text { 10 NRS and presented as } \\
\text { mean sores } \\
\text { Opioid use defined as } \\
\text { morphine equivalents } \\
\text { (conversions not given) } \\
\text { and presented in mg } \\
\text { IVF defined as total } \\
\text { volume of IVF } \\
\text { administered in ml } \\
\text { Length of time to } \\
\text { ambulation defined as } \\
\text { mean hours and obtained } \\
\text { from nursing flowsheet }\end{array}$ & $\begin{array}{l}\text { ERP shortened hospital LOS by } \\
2.07 \text { hours ( } 29.93 \text { vs. } 27.86 \text { hours, } \\
\mathrm{p}=0.041) \\
\text { Discharge before noon doubled in } \\
\text { ERP group }(60.2 \% \text { vs. } 32.9 \% \text {, } \\
\mathrm{p}=0.0002) \\
\text { - } \text { ERP slightly reduced mean pain } \\
\text { score of DOS ( } 4.49 \text { vs. } 4.26, \\
\mathrm{p}=0.545) \\
\text { ERP improved patient self-report of } \\
\text { pain control via HCAHPS (63.6\% } \\
\text { vs. } 81.1 \%, \mathrm{p}=0.0065) \\
\text { - ERP reduced total morphine } \\
\text { equivalents ( } 37.40 \text { mg vs. } 19.40 \mathrm{mg}, \\
\mathrm{p}<0.0001) \\
\text { - ERP reduced total IVF ( } 1403 \mathrm{ml} \text { vs. } \\
690 \text { m, }<0.0001) \\
\text { ERP improved patient satisfaction } \\
\text { ( } 71.4 \text { vs. } 90.9 \% \text { would recommend) } \\
\text { Average total } 30 \text {-day total hospital } \\
\text { cost not significantly different } \\
{[\$ 7908+/-3339 \text { vs. } \$ 8072+/-4077} \\
\text { (p=0.787)] } \\
\text { ERP decreased average time to } \\
\text { ambulation in hours } \\
\text { No difference between ERP group } \\
\text { and control in complications and } \\
\text { readmission rates }\end{array}$ \\
\hline
\end{tabular}




\begin{tabular}{|c|c|c|c|c|c|}
\hline & & & & $\begin{array}{l}\text { Patient satisfaction defined } \\
\text { by HCAHPS and presented } \\
\text { as percentage } \\
\text { Hospital costs defined as } \\
\text { direct and indirect mean } \\
\text { costs at } 30 \text { days } \\
\text { Readmission rates and } \\
\text { complications collectively } \\
\text { defined as SSI, UTI, } \\
\text { transfusions, unplanned } \\
\text { return to the operating } \\
\text { room, unplanned } \\
\text { intubation, acute renal } \\
\text { failure, cardiac arrest, } \\
\text { sepsis/septic shock, death } \\
\text { in } 30 \text { days, total } \\
\text { complications within } 30 \\
\text { days of operation }\end{array}$ & \\
\hline $\begin{array}{l}\text { Wijk, L., Udumyan, R., } \\
\text { Pache, B., Altman, A. } \\
\text { D., Williams, L. L., } \\
\text { Elias, K. M., McGee, } \\
\text { J., Wells, T., Gramlich, } \\
\text { L., Holcomb, K., } \\
\text { Achtari, C., Ljungqvist, } \\
\text { O., Dowdy, S. C., \& } \\
\text { Nelson, G. (2019). } \\
\text { International validation } \\
\text { of enhanced recovery } \\
\text { after surgery society } \\
\text { guidelines on enhanced } \\
\text { recovery for } \\
\text { gynecologic surgery. } \\
\text { American Journal } \\
\text { Obstetrical } \\
\text { Gynecology, 221(3), } \\
\text { 237e1-237e11. } \\
\text { https://doi.org/10.1016/ } \\
\text { j.ajog.2019.04.028 }\end{array}$ & $\begin{array}{l}\text { Design: } \\
\text { Cohort study } \\
\text { Level: } 3 \\
\text { Quality } \\
\text { Grade: B }\end{array}$ & $\begin{array}{l}\text { Sample: 2,101 } \\
\text { patients } \\
\text { undergoing } \\
\text { elective } \\
\text { gynecology/ } \\
\text { oncology } \\
\text { surgery } \\
\text { (427 pre- } \\
\text { ERAS,1674 } \\
\text { post-ERAS) }\end{array}$ & $\begin{array}{l}\text { Intervention: } \\
\text { ERAS protocol } \\
\text { including } \\
\text { preoperative, } \\
\text { perioperative, } \\
\text { intraoperative \& } \\
\text { postoperative } \\
\text { variables } \\
\text { Comparison: } \\
\text { Standard care }\end{array}$ & $\begin{array}{l}\text { Provider compliance with } \\
\text { ERAS described in } \\
\text { percentage in categories } \\
\text { LOS defined as time spent } \\
\text { in hospital during stay } \\
\text { from operation to } \\
\text { discharge described in } \\
\text { median range } \\
\text { Total complications } \\
\text { defined as complications } \\
\text { during primary stay and/or } \\
\text { in } 30 \text {-days after discharge } \\
\text { described as Grade } 1-5 \text { on } \\
\text { Clavien-Dindo system and } \\
\text { presented as percentage }\end{array}$ & $\begin{array}{l}\text { - } \begin{array}{l}\text { A dose-response relationship } \\
\text { between number of elements in }\end{array} \\
\text { ERAS program and outcomes } \\
\text { (compliance improved outcomes) } \\
\text { - } \quad \begin{array}{l}\text { ERAS reduced LOS by } 2 \text { days } \\
(p<0.001)\end{array} \\
\text { - } \quad \begin{array}{l}\text { ERAS did not increase total } \\
\text { complication rate }(p<0.001)\end{array}\end{array}$ \\
\hline
\end{tabular}




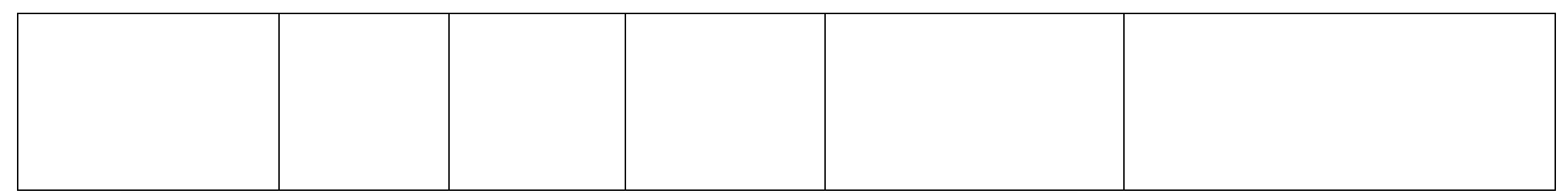

Legend: controlled clinical trial (CCT), conventional care (CC), date of surgery (DOS), enhanced recovery program (ERP), electronic health record (EHR), enhanced recovery after surgery (ERAS), European organization for research and treatment (EORTC), fast track (FT), fast-track multidisciplinary treatment (FTMDT), fast track surgery (FTS), gastrointestinal (GI), Hospital Consumer Assessment of Healthcare Providers and Systems (HCAHPS), intravenous fluid (IVF), laparoscopic (lap), length of stay (LOS), milligram (mg), milliliter (ml), minimally invasive gynecologic surgery (MIGS), Multidimensional Fatigue Inventory 20 (MFI-20), nonsteroidal anti-inflammatory drugs (NSAID), patient-reported outcomes (PROs), postoperative day (POD), postoperative hospital stay (PHS), primary hospital stay (PHS), randomized control trial (RCT), Short Form 36 (SF-36), surgical site infection (SSI), total length of stay (TLOS = PHS + days spent after readmission), transversus abdominus plane block (TAP), urinary tract infection (UIT), verbal rating scale (VRS), ventral hernia repair (VHR), relative risk (RR), standard mean deviations (SMD), visual analogue scale (VAS) 


\section{Appendix B}

\section{Summary of Systematic Reviews (SR)}

\begin{tabular}{|c|c|c|c|c|c|c|c|}
\hline Citation & Quality Grade & Question & Search Strategy & $\begin{array}{c}\text { Inclusion/ } \\
\text { Exclusion } \\
\text { Criteria }\end{array}$ & $\begin{array}{c}\text { Outcomes/Data } \\
\text { Extraction/ } \\
\text { Analysis }\end{array}$ & Key Findings & $\begin{array}{c}\text { Usefulness/ } \\
\text { Recommendations/ } \\
\text { Implications }\end{array}$ \\
\hline $\begin{array}{l}\text { Bickett, M. C., } \\
\text { Long, J. J., } \\
\text { Pronvost, P. J., } \\
\text { Alexander, G. C., } \\
\text { \& Wu, C. L. } \\
\text { (2017). } \\
\text { Prescription } \\
\text { opioid analgesics } \\
\text { commonly unused } \\
\text { after surgery: A } \\
\text { systematic review. } \\
\text { JAMA Surgery, } \\
\text { 152(11), 1066- } \\
1071 . \\
\text { https://doi.org/10. } \\
1001 / \text { jamsurg.201 } \\
7.0831\end{array}$ & $\begin{array}{l}\text { Design: } \\
\text { Systematic review } \\
\text { Level: } 1 \\
\text { Quality Grade: A }\end{array}$ & $\begin{array}{l}\text { Quantify how } \\
\text { many prescription } \\
\text { opioids are } \\
\text { unused, why, and } \\
\text { practices for safe } \\
\text { storage and } \\
\text { disposal }\end{array}$ & $\begin{array}{l}\text { Use of PRISMA, } \\
\text { Meta-Analyses } \\
\text { guidelines, and } \\
\text { PROSPERO } \\
\text { guidelines in } \\
\text { MEDLINE, } \\
\text { EMBASE, and } \\
\text { Cochrane Central } \\
\text { Register of } \\
\text { Controlled Trials } \\
\text { from inception to } \\
\text { October 18, } 2016 \\
\text { Keywords: opioid } \\
\text { oversupply, } \\
\text { prescription } \\
\text { opioids, unused } \\
\text { opioids, surgery } \\
\text { Search identified } \\
6 \text { studies with } 810 \\
\text { patients } \\
\text { undergoing } 7 \\
\text { surgical } \\
\text { procedures }\end{array}$ & $\begin{array}{l}\text { Inclusion criteria: } \\
\text { cross-sectional, } \\
\text { cohort studies, } \\
\text { and RCTs of adult } \\
\text { in-patient and out- } \\
\text { patient surgical } \\
\text { procedures } \\
\text { prescribed an oral } \\
\text { opioid medication } \\
\text { by a medical } \\
\text { professional at the } \\
\text { time of } \\
\text { postsurgical } \\
\text { discharge } \\
\text { reporting unused } \\
\text { opioid medication } \\
\text { Exclusion criteria: } \\
\text { retrospective } \\
\text { studies, discussion } \\
\text { of nonsurgical or } \\
\text { pediatric (age <18 } \\
\text { years) patients, } \\
\text { and no report of } \\
\text { the outcome of } \\
\text { unused opioids }\end{array}$ & $\begin{array}{l}\text { Outcome: opioid- } \\
\text { oversupply } \\
\text { defined as unused } \\
\text { prescriptions \& } \\
\text { unfilled } \\
\text { prescriptions } \\
\text { Two reviewers } \\
\text { independently } \\
\text { assessed } 2419 \\
\text { nonduplicate } \\
\text { studies, 95 studies } \\
\text { passed title and } \\
\text { abstract screening, } \\
6 \text { (6\%) fulfilled } \\
\text { the inclusion } \\
\text { criteria } \\
\text { Study } \\
\text { characteristics } \\
\text { included study } \\
\text { design, setting, } \\
\text { patient population, } \\
\text { surgery type, } \\
\text { opioid } \\
\text { prescription } \\
\text { characteristics, } \\
\text { unused opioid } \\
\text { tablets, reasons } \\
\text { for stopping or not } \\
\text { using opioid } \\
\text { therapy, and }\end{array}$ & $\begin{array}{l}67 \%-92 \% \text { of } \\
\text { patients reported } \\
\text { unused opioids } \\
\text { Patients reported } \\
\text { stopping opioid } \\
\text { use related to } \\
\text { pain control } \\
16 \%-29 \% \text { of } \\
\text { patients reported } \\
\text { opioid-induced } \\
\text { side effects } \\
\text { All studies } \\
\text { reported low } \\
\text { rates of } \\
\text { anticipated or } \\
\text { actual disposal }\end{array}$ & $\begin{array}{l}\text { Opioids prescribed } \\
\text { for postoperative } \\
\text { pain control go } \\
\text { unused, unlocked, } \\
\text { and are not properly } \\
\text { disposed of, which } \\
\text { may lead to injury } \\
\text { or death }\end{array}$ \\
\hline
\end{tabular}




\begin{tabular}{|c|c|c|c|c|c|c|c|}
\hline Citation & Quality Grade & Question & Search Strategy & $\begin{array}{c}\text { Inclusion/ } \\
\text { Exclusion } \\
\text { Criteria } \\
\end{array}$ & $\begin{array}{c}\text { Outcomes/Data } \\
\text { Extraction/ } \\
\text { Analysis }\end{array}$ & Key Findings & $\begin{array}{c}\text { Usefulness/ } \\
\text { Recommendations/ } \\
\text { Implications }\end{array}$ \\
\hline & & & & & $\begin{array}{l}\text { opioid storage and } \\
\text { disposal } \\
\text { characteristics } \\
\text { documented in } \\
\text { data table } \\
\text { Extracted data } \\
\text { was aggregated } \\
\text { and qualitatively } \\
\text { summarized by } \\
\text { outcomes across } \\
\text { surgery type due } \\
\text { to differences in } \\
\text { patient } \\
\text { populations }\end{array}$ & & \\
\hline $\begin{array}{l}\text { Feinberg, A. E., } \\
\text { Chesney, T. R., } \\
\text { Srikandarajah, S., } \\
\text { Acuna, S. A., } \\
\text { McLeod, R. S., \& } \\
\text { Best Practice in } \\
\text { Surgery Group. } \\
\text { (2018). Opioid } \\
\text { use after } \\
\text { discharge in } \\
\text { postoperative } \\
\text { patients: A } \\
\text { systematic review. } \\
\text { Annals of Surgery, } \\
\text { 267(6), 1056- } \\
\text { 1062. } \\
\text { https://doi.org/10. } \\
1097 / \text { SLA.000000 } \\
000002591 \\
\end{array}$ & $\begin{array}{l}\text { Design: } \\
\text { Systematic review } \\
\text { Level: } 1 \\
\text { Quality Grade: A } \\
\end{array}$ & $\begin{array}{l}\text { Describe post- } \\
\text { discharge opioid } \\
\text { consumption and } \\
\text { prescription } \\
\text { patterns by } \\
\text { providers for } \\
\text { surgical patients }\end{array}$ & $\begin{array}{l}\text { Utilization of } \\
\text { Reporting Items } \\
\text { for Systematic } \\
\text { Reviews and } \\
\text { PRISMA } \\
\text { guidelines for a } \\
\text { systematic } \\
\text { literature review } \\
\text { in Medline and } \\
\text { EMBASE from } \\
\text { inception to } \\
\text { December 17, } \\
\text { 2016 } \\
\text { Keywords: opioid } \\
\text { use, post- } \\
\text { discharge, surgical } \\
\text { patients, } \\
\text { systematic review }\end{array}$ & $\begin{array}{l}\text { Inclusion criteria: } \\
\text { Any language, } \\
\text { human clinical } \\
\text { study quantifying } \\
\text { opioid use for } \\
\text { postoperative } \\
\text { patients after } \\
\text { hospital discharge } \\
\text { Exclusion criteria: } \\
\text { studies reporting } \\
\text { only on inpatient } \\
\text { opioid use }\end{array}$ & $\begin{array}{l}\text { Outcomes: } \\
\text { Post-discharge } \\
\text { opioid } \\
\text { consumption } \\
\text { defined as number } \\
\text { of pills used and } \\
\text { unused and } \\
\text { described as mean } \\
\\
\text { Pain control } \\
\text { defined on VRS } \\
0-10 \text { and } \\
\text { described as mean } \\
\text { scores } \\
\text { Disposal methods } \\
\text { defined as proper } \\
\text { versus improper } \\
\text { disposal planned } \\
\text { (yes/no) }\end{array}$ & $\begin{array}{l}\text { Median opioid } \\
\text { consumption } 15 \\
\text { pills or less } \\
\text { Proportion of } \\
\text { used opioids } \\
\text { ranged from } \\
5.6 \%-59.1 \% \\
\text { Pain scores } \\
\text { ranged from 2- } \\
5 / 10 \\
70 \% \text { of patients } \\
\text { kept unused } \\
\text { opioids }\end{array}$ & $\begin{array}{l}\text { Surgical patients } \\
\text { using less opioids } \\
\text { than prescribed } \\
\text { postoperatively } \\
\text { Patients lack } \\
\text { awareness regarding } \\
\text { proper disposal } \\
\text { Education of } \\
\text { patients and } \\
\text { providers necessary } \\
\text { regarding } \\
\text { postoperative opioid } \\
\text { prescribing }\end{array}$ \\
\hline
\end{tabular}




\begin{tabular}{|c|c|c|c|c|c|c|c|}
\hline Citation & Quality Grade & Question & Search Strategy & $\begin{array}{c}\text { Inclusion/ } \\
\text { Exclusion } \\
\text { Criteria } \\
\end{array}$ & $\begin{array}{c}\text { Outcomes/Data } \\
\text { Extraction/ } \\
\text { Analysis } \\
\end{array}$ & Key Findings & $\begin{array}{c}\text { Usefulness/ } \\
\text { Recommendations/ } \\
\text { Implications }\end{array}$ \\
\hline & & & $\begin{array}{l}\text { MeSH descriptors } \\
\text { included "pain, } \\
\text { postoperative," } \\
\text { ""narcotics," } \\
\text { "analgesics, } \\
\text { opioid," or } \\
\text { "opioid-related } \\
\text { disorders" } \\
\text { combined with } \\
\text { "practice patterns, } \\
\text { physicians," "drug } \\
\text { prescriptions," } \\
\text { "drug utilization," } \\
\text { or "drug } \\
\text { utilization review" } \\
\text { Search identified } \\
11 \text { patient survey } \\
\text { studies reporting } \\
\text { opioid use in } \\
3,525 \text { surgical } \\
\text { patients } \\
\text { undergoing } \\
\text { abdominal, } \\
\text { orthopedic, tooth } \\
\text { extraction, and } \\
\text { dermatologic } \\
\text { procedures }\end{array}$ & & $\begin{array}{l}\text { Two reviewers } \\
\text { independently } \\
\text { assessed } 2429 \\
\text { nonduplicate } \\
\text { studies, } 31 \text { passed } \\
\text { title and abstract } \\
\text { screening, } \\
\text { 11fulfilled } \\
\text { inclusion criteria } \\
\\
\text { Descriptive } \\
\text { statistics were } \\
\text { used to describe } \\
\text { characteristics and } \\
\text { outcomes }\end{array}$ & & \\
\hline $\begin{array}{l}\text { Kalogera, E., } \\
\text { Glaser, G. E., } \\
\text { Kumar, A., } \\
\text { Dowdy, S. C., \& } \\
\text { Langstraat, C. L. } \\
\text { (2019). Enhanced } \\
\text { recovery after } \\
\text { minimally } \\
\end{array}$ & $\begin{array}{l}\text { Design: } \\
\text { Systematic review } \\
\text { Level: } 1 \\
\text { Quality Grade: A }\end{array}$ & $\begin{array}{l}\text { What does current } \\
\text { published } \\
\text { literature on } \\
\text { ERAS for MIGS } \\
\text { with bowel } \\
\text { surgery } \\
\text { demonstrate } \\
\text { related to }\end{array}$ & $\begin{array}{l}\text { Literature search } \\
\text { in PubMed, } \\
\text { Medline, and } \\
\text { Ovid EMBASE } \\
\text { before May } 2018 \\
\\
\text { Keywords: ERAS, } \\
\text { ERP, fast-track }\end{array}$ & $\begin{array}{l}\text { Inclusion criteria: } \\
\text { RCTs, cohort } \\
\text { studies, case } \\
\text { control studies, } \\
\text { and case series } \\
\text { studies focused on } \\
\text { MIGS or } \\
\text { minimally }\end{array}$ & $\begin{array}{l}\text { Outcomes: LOS } \\
\text { defined as mean } \\
\text { or median hours } \\
\text { in the recovery } \\
\text { room or days in } \\
\text { the hospital }\end{array}$ & $\begin{array}{l}\text { ERAS shortened } \\
\text { hospital LOS } \\
\text { ERAS increased } \\
\text { same-day } \\
\text { discharge }\end{array}$ & $\begin{array}{l}\text { ERAS represents } \\
\text { best clinical practice } \\
\text { to reduce LOS, } \\
\text { morbidity, and } \\
\text { readmission rates. } \\
\text { This is consistent } \\
\text { with literature. }\end{array}$ \\
\hline
\end{tabular}




\begin{tabular}{|c|c|c|c|c|c|c|c|}
\hline Citation & Quality Grade & Question & Search Strategy & $\begin{array}{c}\text { Inclusion/ } \\
\text { Exclusion } \\
\text { Criteria } \\
\end{array}$ & $\begin{array}{c}\text { Outcomes/Data } \\
\text { Extraction/ } \\
\text { Analysis }\end{array}$ & Key Findings & $\begin{array}{c}\text { Usefulness/ } \\
\text { Recommendations/ } \\
\text { Implications }\end{array}$ \\
\hline $\begin{array}{l}\text { invasive } \\
\text { gynecologic } \\
\text { procedures with } \\
\text { bowel surgery: A } \\
\text { systematic review. } \\
\text { Journal of } \\
\text { Minimally } \\
\text { Invasive } \\
\text { Gynecology, } \\
26(2), 288-298 . \\
\text { https://doi.org/10. } \\
1016 / \text { j.jmig.2018. } \\
10.016 \\
\end{array}$ & & $\begin{array}{l}\text { postoperative } \\
\text { outcomes, LOS, } \\
\text { costs, } \\
\text { complication, and } \\
\text { readmissions }\end{array}$ & $\begin{array}{l}\text { MIGS, } \\
\text { laparoscopy, } \\
\text { robotic, } \\
\text { gynecologic, } \\
\text { bowel surgery, } \\
\text { bowel resection, } \\
\text { colon resection, } \\
\text { colectomy, } \\
\text { sigmoidectomy, } \\
\text { rectosigmoid- } \\
\text { ectomy, rectal } \\
\text { resection, } \\
\text { ileocolic resection } \\
\text { Search identified } \\
12 \text { RCTs studies }\end{array}$ & $\begin{array}{l}\text { invasive subset, } \\
\text { English language, } \\
\text { sample larger than } \\
\text { 10, evaluating } \\
\text { LOS, } \\
\text { perioperative } \\
\text { complication, and } \\
\text { readmission } \\
\text { Exclusion criteria: } \\
\text { review articles, } \\
\text { sample size <10, } \\
\text { relevant outcomes } \\
\text { not reported, no } \\
\text { separate analysis } \\
\text { of MIGS }\end{array}$ & $\begin{array}{l}\text { Patient } \\
\text { satisfaction } \\
\text { defined in survey } \\
\text { as "exactly happy } \\
\text { with experience" } \\
\text { and presented as } \\
\text { percentage of pre- } \\
\text { and post-Likert } \\
\text { showing } \\
\text { improvement in } \\
\text { pain control } \\
\text { Opioid use } \\
\text { defined as } \\
\text { morphine } \\
\text { equivalents } \\
\text { (conversions not } \\
\text { given) and } \\
\text { presented in mg } \\
\text { Costs defined as } \\
\text { mean total } \\
\text { hospital costs } \\
\text { and/or median } 30 \text { - } \\
\text { day total hospital } \\
\text { cost per patient } \\
\text { Complication rate } \\
\text { defined as } \\
\text { percentage of } \\
\text { urgent care or ER } \\
\text { visits, re- } \\
\text { operation, } \\
\text { Clavien-Dindo } \\
\text { classification, } \\
\text { Accordion } \\
\text { classification, }\end{array}$ & $\begin{array}{l}\text { ERAS improved } \\
\text { patient } \\
\text { satisfaction } \\
\text { ERAS reduced } \\
\text { opioid use } \\
\text { ERAS reduced } \\
\text { costs } \\
\text { ERAS did not } \\
\text { increase } \\
\text { complications } \\
\text { ERAS did not } \\
\text { increase 30-day } \\
\text { readmission rates } \\
\text { Variation } \\
\text { between ERAS } \\
\text { protocols showed } \\
\text { need for } \\
\text { standardization }\end{array}$ & \\
\hline
\end{tabular}




\begin{tabular}{|c|c|c|c|c|c|c|c|}
\hline Citation & Q Quality Grade & Question & Search Strategy & $\begin{array}{c}\text { Inclusion/ } \\
\text { Exclusion } \\
\text { Criteria } \\
\end{array}$ & $\begin{array}{c}\begin{array}{c}\text { Outcomes/Data } \\
\text { Extraction/ } \\
\text { Analysis }\end{array} \\
\end{array}$ & Key Findings & $\begin{array}{c}\text { Usefulness/ } \\
\text { Recommendations/ } \\
\text { Implications }\end{array}$ \\
\hline & & & & & $\begin{array}{l}\text { morbidity, or } \\
\text { mortality at } 30 \text { or } \\
90 \text { days } \\
\text { Readmission rates } \\
\text { defined as } \\
\text { percentage of } \\
\text { patients } \\
\text { readmitted within } \\
30 \text { or } 90 \text { days } \\
\text { Authors assessed } \\
96 \text { nonduplicate } \\
\text { studies, } 26 \text { passed } \\
\text { title and abstract } \\
\text { screening, } 12 \\
\text { fulfilled inclusion } \\
\text { criteria } \\
\text { Data collection } \\
\text { tool detailed } \\
\text { reference, year, } \\
\text { study design, type } \\
\text { of surgery, } \\
\text { comparator, } \\
\text { number of patients } \\
\text { and LOS } \\
\text { Data was } \\
\text { extracted } \\
\text { regarding ERAS } \\
\text { pathway } \\
\text { components into a } \\
\text { data collection } \\
\text { tool }\end{array}$ & & \\
\hline
\end{tabular}




\begin{tabular}{|c|c|c|c|c|c|c|c|}
\hline Citation & Quality Grade & Question & Search Strategy & $\begin{array}{c}\text { Inclusion/ } \\
\text { Exclusion } \\
\text { Criteria } \\
\end{array}$ & $\begin{array}{c}\text { Outcomes/Data } \\
\text { Extraction/ } \\
\text { Analysis }\end{array}$ & Key Findings & $\begin{array}{c}\text { Usefulness/ } \\
\text { Recommendations/ } \\
\text { Implications }\end{array}$ \\
\hline $\begin{array}{l}\text { Smith, G. B., } \\
\text { Belgamukar, A. } \\
\text { P., Davidson, B. } \\
\text { R., \& Gurusamy, } \\
\text { K. S. (2016). } \\
\text { Enhanced } \\
\text { recovery protocols } \\
\text { for major upper } \\
\text { gastrointestinal, } \\
\text { liver, and } \\
\text { pancreatic } \\
\text { surgery. Cochrane } \\
\text { Database of } \\
\text { Systematic } \\
\text { Reviews, 2. } \\
\text { https://doi.org/10. } \\
1002 / 14651858 . C \\
\text { D011382.pub2 } \\
\end{array}$ & $\begin{array}{l}\text { Design: } \\
\text { Systematic review } \\
\text { Level: } 1 \\
\text { Quality Grade: A } \\
\end{array}$ & $\begin{array}{l}\text { Evaluate the } \\
\text { benefits and risks } \\
\text { of ERAS } \\
\text { compared with } \\
\text { standard care in } \\
\text { major upper } \\
\text { gastrointestinal, } \\
\text { liver and } \\
\text { pancreatic surgery }\end{array}$ & $\begin{array}{l}\text { Literature search } \\
\text { in Cochrane } \\
\text { Central Register } \\
\text { of Controlled } \\
\text { Trials, } \\
\text { MEDLINE, } \\
\text { EMBASE, and } \\
\text { Science Citation } \\
\text { Index Expanded } \\
\text { from inception to } \\
\text { March, } 262015 \\
\\
\text { Search identified } \\
10 \text { RCTs } \\
\text { including } 1,014 \\
\text { patients }\end{array}$ & $\begin{array}{l}\text { Inclusion: } \\
\text { RCTs performed } \\
\text { in people } \\
\text { undergoing major } \\
\text { upper } \\
\text { gastrointestinal, } \\
\text { liver and } \\
\text { pancreatic } \\
\text { surgery, } \\
\text { irrespective of } \\
\text { language, blinding } \\
\text { or publication } \\
\text { status for } \\
\text { inclusion in the } \\
\text { review }\end{array}$ & $\begin{array}{l}\text { Outcomes: short- } \\
\text { term mortality } \\
\text { defined as in- } \\
\text { hospital mortality } \\
\text { or mortality } \\
\text { within three } \\
\text { months } \\
\text { Adverse events } \\
\text { within } 3 \text { months } \\
\text { defined by } \\
\text { Clavien-Dindo } \\
\text { classification } \\
\text { and/or } \\
\text { International } \\
\text { Conference on } \\
\text { Harmonisation-- } \\
\text { Good Clinical } \\
\text { Practice } \\
\text { Health-related } \\
\text { quality of life } \\
\text { defined using any } \\
\text { validated scales } \\
\text { presented in } \\
\text { means } \\
\text { LOS defined as } \\
\text { mean days } \\
\text { Costs converted } \\
\text { costs to the single } \\
\text { currency of USD } \\
\text { based on the } \\
\text { existing } \\
\text { conversion rate on } \\
\text { the day of the } \\
\text { analysis }\end{array}$ & \begin{tabular}{|l|} 
ERAS groups \\
had less mild \\
adverse events \\
(109 vs. 188 per \\
$1000)$ \\
ERAS groups \\
had decreased \\
serious events \\
(76 vs. 105 per \\
$1000)$ \\
Control groups \\
had decreased \\
short-term \\
mortality (6 vs. 2 \\
per 1000$)$ \\
\\
ERAS improved \\
health-related \\
quality of life \\
0.29 standard \\
deviations higher \\
$(0.04$ lower to \\
0.62 higher) \\
ERAS reduced \\
the mean LOS by \\
2.19 (2.53 to \\
1.85 ) days \\
ERAS groups \\
had decreased \\
cost \\
\end{tabular} & $\begin{array}{l}\text { ERAS protocols } \\
\text { may reduce length } \\
\text { of hospital stay and } \\
\text { costs (primarily } \\
\text { because of reduction } \\
\text { in hospital stay) in } \\
\text { people undergoing } \\
\text { major upper } \\
\text { gastrointestinal, } \\
\text { liver and pancreatic } \\
\text { surgeries }\end{array}$ \\
\hline
\end{tabular}




\begin{tabular}{|c|c|c|c|c|c|c|c|}
\hline Citation & Quality Grade & Question & Search Strategy & $\begin{array}{c}\text { Inclusion/ } \\
\text { Exclusion } \\
\text { Criteria } \\
\end{array}$ & \begin{tabular}{|c|} 
Outcomes/Data \\
Extraction/ \\
Analysis \\
\end{tabular} & Key Findings & $\begin{array}{c}\text { Usefulness/ } \\
\text { Recommendations/ } \\
\text { Implications }\end{array}$ \\
\hline & & & & & $\begin{array}{l}\text { Two reviewers } \\
\text { independently } \\
\text { assessed and } \\
2,731 \\
\text { nonduplicate } \\
\text { studies, } 30 \text { passed } \\
\text { title and abstract } \\
\text { screening, } 10 \\
\text { fulfilled inclusion } \\
\text { criteria and data } \\
\text { was extracted } \\
\text { Authors } \\
\text { calculated the RR, } \\
\text { MD, or SMD with } \\
95 \% \text { CIs using } \\
\text { both fixed-effect } \\
\text { and random- } \\
\text { effects models } \\
\text { with Review } \\
\text { Manager 5, based } \\
\text { on available case } \\
\text { analysis }\end{array}$ & & \\
\hline
\end{tabular}




\begin{tabular}{|c|c|c|c|c|c|c|c|}
\hline Citation & 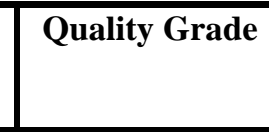 & Question & Search Strategy & $\begin{array}{c}\text { Inclusion/ } \\
\text { Exclusion } \\
\text { Criteria }\end{array}$ & $\begin{array}{c}\text { Outcomes/Data } \\
\text { Extraction/ } \\
\text { Analysis }\end{array}$ & Key Findings & $\begin{array}{c}\text { Usefulness/ } \\
\text { Recommendations/ } \\
\text { Implications }\end{array}$ \\
\hline $\begin{array}{l}\text { Spanjersberg, W. } \\
\text { R., van Sambeek, } \\
\text { J. D., Bremers, A. } \\
\text { Rosman, C., \& } \\
\text { van Laarhoven, C } \\
\text { J. (2015). } \\
\text { Systematic review } \\
\text { and meta-analysis } \\
\text { for laparoscopic } \\
\text { versus open } \\
\text { surgery with or } \\
\text { without an ERAS } \\
\text { programme. } \\
\text { Surgical } \\
\text { Endoscopy, } \\
29(12), 3443- \\
\text { 3453. } \\
\text { https://doi.org/10. } \\
1007 / \text { s00464-015 } \\
4148-3 \\
\end{array}$ & \begin{tabular}{|l} 
Design: \\
Systematic \\
review/meta- \\
analysis \\
Level: 1 \\
Quality Grade: A
\end{tabular} & \begin{tabular}{|l|} 
Determine \\
whether \\
combining lap and \\
ERAS have \\
additional value \\
within colorectal \\
surgery \\
\end{tabular} & $\begin{array}{l}\text { Systematic search } \\
\text { of MEDLINE, } \\
\text { PubMed, } \\
\text { EMBASE and } \\
\text { Cochrane } \\
\text { databases } \\
\text { inception to } \\
\text { March, 2014 } \\
\text { Search identified } \\
10 \text { RCTs } \\
\text { including 1,014 } \\
\text { patients } \\
\text { 408 patients from } \\
3 \text { RCTs and 6 } \\
\text { CCTs received lap } \\
\text { ERAS care and } \\
189 \text { received lap } \\
\text { conventional care, } \\
\text { and } 247 \text { received } \\
\text { open ERAS care }\end{array}$ & $\begin{array}{l}\text { Inclusion: } \\
\text { Prospective trials } \\
\text { with colorectal } \\
\text { surgical patients } \\
\text { comparing lap } \\
\text { patients with or } \\
\text { without ERAS or } \\
\text { comparing all } \\
\text { ERAS patients } \\
\text { with or without } \\
\text { lap intervention } \\
\text { Exclusion criteria: } \\
\text { Not peer- } \\
\text { reviewed, dual } \\
\text { publications, late } \\
\text { follow-up } \\
\end{array}$ & $\begin{array}{l}\text { Primary outcomes } \\
\text { both research } \\
\text { question: PLS and } \\
\text { TLOS- all studies } \\
\text { reported hospital } \\
\text { stay as median } \\
\text { with interquartile } \\
\text { ranges } \\
\text { Complications- } \\
\text { major- mortality, } \\
\text { abdominal sepsis, } \\
\text { anastomotic } \\
\text { leakage, need for } \\
\text { reoperation, } \\
\text { persistent ileus, } \\
\text { intra-abdominal } \\
\text { abscesses, } \\
\text { bleeding, burst } \\
\text { abdomen } \\
\text { (Platzbauch), late } \\
\text { incisional hernia } \\
\text { and adhesions } \\
\text { Minor } \\
\text { complications- } \\
\text { pneumonia, } \\
\text { wound infection, } \\
\text { deep vein } \\
\text { thrombosis and } \\
\text { urinary tract } \\
\text { infection- all } \\
\text { reported as a } \\
\text { number of events, } \\
\text { odds ratio, } 95 \% \\
\text { CI, percentage, } \\
\text { effect and } p \text {-value }\end{array}$ & \begin{tabular}{|l|} 
Lap operated \\
patients \\
with/without \\
ERAS, no \\
differences in \\
morbidity, minor \\
and major \\
complication, \\
and \\
postoperative \\
hospital stay \\
favored ERAS \\
(MD -2.34 \\
{$[-3.77$,} \\
-0.91], $Z=3.20$, \\
$p=0.001)$ \\
Lap and open \\
surgery within \\
ERAS, major \\
morbidity was \\
significantly \\
reduced in the \\
laparoscopic \\
group (OR 0.42 \\
{$[0.26$,} \\
$0.66], Z=3.73$, \\
$p=0.006)$ \\
No difference \\
noted in quality \\
of life between \\
open and lap \\
ERAS, but $88 \%$ \\
of lap vs. $58 \%$ of \\
open felt \\
recovered at 12
\end{tabular} & $\begin{array}{l}\text { Results show a } \\
\text { significant } \\
\text { reduction in major } \\
\text { morbidity in favor } \\
\text { of lap compared to } \\
\text { open surgery within } \\
\text { ERAS care while } \\
\text { there was no } \\
\text { difference in } \\
\text { complications } \\
\text { between } \\
\text { conventional care } \\
\text { and ERAS in the } \\
\text { laparoscopic group } \\
\text { Conclusion is lap } \\
\text { has a (major) } \\
\text { additional/synergist } \\
\text { ic effect within } \\
\text { ERAS care, } \\
\text { especially related to } \\
\text { LOS }\end{array}$ \\
\hline
\end{tabular}




\begin{tabular}{|c|c|c|c|c|c|c|c|}
\hline Citation & Quality Grade & Question & Search Strategy & $\begin{array}{c}\text { Inclusion/ } \\
\text { Exclusion } \\
\text { Criteria }\end{array}$ & $\begin{array}{c}\text { Outcomes/Data } \\
\text { Extraction/ } \\
\text { Analysis }\end{array}$ & Key Findings & \begin{tabular}{|c|} 
Usefulness/ \\
Recommendations/ \\
Implications
\end{tabular} \\
\hline & & & & & $\begin{array}{l}\text { Secondary } \\
\text { outcomes: quality } \\
\text { of life (survey at } 2 \\
\text { and } 4 \text { weeks), } \\
\text { gastrointestinal } \\
\text { function, pain and } \\
\text { pain medication, } \\
\text { cost } \\
\text { Opioid pills } \\
\text { defined as } \\
\text { morphine } \\
\text { equivalents: } 1 \\
\text { table hydrocodone } \\
5 \text { mg }=5 \text { oral } \\
\text { morphine } \\
\text { equivalents, } \\
\text { oxycodone } 5 \text { mg }= \\
7.5 \text { oral morphine } \\
\text { equivalents, } \\
\text { codeine } 30 \text { mg }= \\
4.5 \text { oral morphine } \\
\text { equivalents, and } \\
\text { hydromorphone } 2 \\
\text { mg = } 8 \text { oral } \\
\text { morphine } \\
\text { equivalents } \\
\\
\text { The search was } \\
\text { independently } \\
\text { performed by two } \\
\text { authors } \\
\text { Studies were } \\
\text { assessed for } \\
\text { quality by using }\end{array}$ & $\begin{array}{l}\text { months } \\
\text { postoperatively } \\
\text { No difference in } \\
\text { GI function } \\
\text { More pain } \\
\text { medication in } \\
\text { open group } \\
\text { Lap surgery cost } \\
\text { more than open } \\
\text { but overall no } \\
\text { significant } \\
\text { difference in } \\
\text { cost of stay } \\
\end{array}$ & \\
\hline
\end{tabular}




\begin{tabular}{|c|c|c|c|c|c|c|c|}
\hline Citation & Q Quality Grade & Question & Search Strategy & $\begin{array}{c}\text { Inclusion/ } \\
\text { Exclusion } \\
\text { Criteria } \\
\end{array}$ & $\begin{array}{c}\text { Outcomes/Data } \\
\text { Extraction/ } \\
\text { Analysis } \\
\end{array}$ & Key Findings & $\begin{array}{c}\text { Usefulness/ } \\
\text { Recommendations/ } \\
\text { Implications } \\
\end{array}$ \\
\hline & & & & & $\begin{array}{l}\text { GRADE } \\
\text { methodology and } \\
\text { analyzed by using } \\
\text { the GRADE } \\
\text { profiler tool } \\
\text { Data extraction } \\
\text { sheets were } \\
\text { utilized } \\
\text { Primary endpoints } \\
\text { analyzed were } \\
\text { complications, } \\
\text { both major and } \\
\text { minor, } \\
\text { readmissions and } \\
\text { length of hospital } \\
\text { stay } \\
\text { Secondary } \\
\text { endpoints } \\
\text { included quality } \\
\text { of life data, } \\
\text { oncological } \\
\text { outcome, pain and } \\
\text { pain medication }\end{array}$ & & \\
\hline $\begin{array}{l}\text { Zhou, J., Fan, Y., } \\
\text { Zhong, J., Wen, } \\
\text { X., \& Chen, H. } \\
\text { (2017). Efficacy } \\
\text { and safety of }\end{array}$ & $\begin{array}{l}\text { Design: Meta- } \\
\text { analysis } \\
\text { Level: } 1\end{array}$ & $\begin{array}{l}\text { Evaluate the } \\
\text { efficacy and } \\
\text { safety of } \\
\text { multimodal } \\
\text { analgesia with }\end{array}$ & $\begin{array}{l}\text { Literature search } \\
\text { in PubMed, } \\
\text { EmBase and The } \\
\text { Cochrane Central }\end{array}$ & $\begin{array}{l}\text { Inclusion: } \\
\text { RCTs aimed at } \\
\text { regional } \\
\text { anesthesia as part } \\
\text { of multimodal }\end{array}$ & $\begin{array}{l}\text { Outcomes: pain } \\
\text { frequency defined } \\
\text { in days presented } \\
\text { as RR and SMDs }\end{array}$ & $\begin{array}{l}\text { Multimodal } \\
\text { analgesia with } \\
\text { addition of } \\
\text { regional } \\
\text { improved pain }\end{array}$ & $\begin{array}{l}\text { Regional anesthesia } \\
\text { is a valuable part of } \\
\text { multimodal } \\
\text { analgesia to reduce }\end{array}$ \\
\hline
\end{tabular}




\begin{tabular}{|c|c|c|c|c|c|c|c|}
\hline Citation & 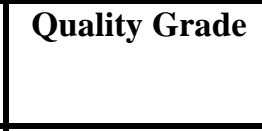 & Question & Search Strategy & $\begin{array}{c}\text { Inclusion/ } \\
\text { Exclusion } \\
\text { Criteria } \\
\end{array}$ & $\begin{array}{c}\text { Outcomes/Data } \\
\text { Extraction/ } \\
\text { Analysis } \\
\end{array}$ & Key Findings & $\begin{array}{c}\text { Usefulness/ } \\
\text { Recommendations/ } \\
\text { Implications }\end{array}$ \\
\hline $\begin{array}{l}\text { multimodal } \\
\text { analgesic } \\
\text { techniques for } \\
\text { preventing } \\
\text { chronic post- } \\
\text { surgery pain } \\
\text { under different } \\
\text { surgical } \\
\text { categories: A } \\
\text { meta-analysis. } \\
\text { Scientific Reports, } \\
7 . \\
\text { https://doi.org/10. } \\
1038 / \mathrm{s} 41598-017- \\
00813-5\end{array}$ & |Quality Grade: A & $\begin{array}{l}\text { regional for } \\
\text { various surgical } \\
\text { categories }\end{array}$ & $\begin{array}{l}\text { Register of } \\
\text { Controlled Trials } \\
\text { Search identified } \\
21 \text { trials with } \\
1,980 \text { patients } \\
\text { undergoing } \\
\text { general, } \\
\text { orthopedic, } \\
\text { gynecological, } \\
\text { and thoracotomy } \\
\text { surgery }\end{array}$ & $\begin{array}{l}\text { prevention of } \\
\text { chronic pain }\end{array}$ & $\begin{array}{l}\text { Analgesia } \\
\text { consumption } \\
\text { described in } \\
\text { number of pills } \\
\text { presented as mean } \\
\text { Pain scale } \\
\text { described by VAS } \\
\text { presented as mean } \\
\text { Two authors } \\
\text { independently } \\
\text { assessed 1,036 } \\
\text { nonduplicate } \\
\text { studies, 41 passed } \\
\text { title and abstract } \\
\text { screening, 21 } \\
\text { fulfilled inclusion } \\
\text { criteria and data } \\
\text { was extracted } \\
\text { Meta-analysis } \\
\text { performed } \\
\text { according to } \\
\text { PRISMA } \\
\text { statement } \\
\text { Random effects } \\
\text { model used to } \\
\text { pool data due to } \\
\text { heterogeneity } \\
\text { Results presented } \\
\text { as SMD, CI, RR } \\
\text { and 95\% CI }\end{array}$ & $\begin{array}{l}\text { frequency (RR } \\
0.69, \mathrm{p}<0.001) \\
\text { Multimodal } \\
\text { analgesia patient } \\
\text { satisfaction was } \\
\text { significantly } \\
\text { higher (SMD } \\
1.95, \mathrm{p}=0.0001)\end{array}$ & $\begin{array}{l}\text { chronic post-surgery } \\
\text { pain }\end{array}$ \\
\hline
\end{tabular}




\begin{tabular}{|c|c|c|c|c|c|c|c|}
\hline Citation & Quality Grade & Question & Search Strategy & $\begin{array}{c}\text { Inclusion/ } \\
\text { Exclusion } \\
\text { Criteria }\end{array}$ & $\begin{array}{c}\text { Outcomes/Data } \\
\text { Extraction/ } \\
\text { Analysis }\end{array}$ & Key Findings & $\begin{array}{c}\text { Usefulness/ } \\
\text { Recommendations } \\
\text { Implications }\end{array}$ \\
\hline $\begin{array}{l}\text { Zhao, J. H., Sun, } \\
\text { J. X., Huang, X. } \\
\text { Z., Gao, P., Chen, } \\
\text { X. W., Song, Y. } \\
\text { X., Liu, J., Cai, } \\
\text { C., Xu, H., \& } \\
\text { Wang, Z. N. } \\
\text { (2016). Meta- } \\
\text { analysis of the } \\
\text { laparoscopic } \\
\text { versus open } \\
\text { colorectal surgery } \\
\text { with fast tract } \\
\text { surgery. } \\
\text { International } \\
\text { Journal of } \\
\text { Colorectal } \\
\text { Disease, 31(3), } \\
\text { 613-622. } \\
\text { https://doi.org/10. } \\
1007 / \text { s00384-015- } \\
2493-2 \\
\end{array}$ & $\begin{array}{l}\text { Meta-analysis of } \\
\text { high-quality } \\
\text { studies } \\
\text { Level:1 } \\
\text { Grade Quality: A }\end{array}$ & $\begin{array}{l}\text { Evaluate } \\
\text { published studies } \\
\text { for the effect of } \\
\text { lap colorectal } \\
\text { surgery within } \\
\text { FTS }\end{array}$ & $\begin{array}{l}\text { Literature search } \\
\text { in PubMed, } \\
\text { EMBASE, } \\
\text { Cochrane Library, } \\
\text { and Ovid } \\
\text { databases for } \\
\text { eligible studies } \\
\text { from inception } \\
\text { until August 1, } \\
2014 \\
\text { Keywords fast } \\
\text { tract, multimodal } \\
\text { rehabilitation, } \\
\text { enhanced } \\
\text { recovery, } \\
\text { colorectal surgery, } \\
\text { colorectal } \\
\text { resection, large } \\
\text { intestine, colon, } \\
\text { rectum, sigmoid, } \\
\text { MIS, lap } \\
\text { Search identified } \\
4 \text { randomized } \\
\text { controlled trials } \\
\text { and six clinical } \\
\text { controlled trials } \\
\text { (1510 patients) }\end{array}$ & $\begin{array}{l}\text { Inclusion criteria: } \\
\text { Publication in } \\
\text { English } \\
\text { comparing lap } \\
\text { with open in } \\
\text { patients } \\
\text { undergoing FTS, } \\
\text { full-text article, } \\
\text { clear FTS } \\
\text { protocol, one } \\
\text { outcome } \\
\text { mentioned } \\
\text { Exclusion criteria: } \\
\text { lap and open was } \\
\text { not compared with } \\
\text { FTS, no FT } \\
\text { protocol }\end{array}$ & $\begin{array}{l}\text { Outcomes: LOS, } \\
\text { time to first bowel } \\
\text { movement, } \\
\text { complication rate, } \\
\text { readmission rate, } \\
\text { mortality after } 30 \\
\text { days } \\
\text { Two authors } \\
\text { independently } \\
\text { extracted data } \\
\text { from articles using } \\
\text { unified data sheet } \\
\text { RCTs evaluated } \\
\text { using JCS } \\
\text { CCC were } \\
\text { evaluated using } \\
\text { Newcastle Ottawa } \\
\text { Scale } \\
\text { Meta-analysis } \\
\text { conducted with } \\
\text { RevMan v5.2 and } \\
\text { Stata v12.0 } \\
\text { RR for } \\
\text { dichotomous } \\
\text { variables } \\
\text { WMD for } \\
\text { continuous } \\
\text { variables } \\
\text { (reported with } \\
95 \% \text { CI as mean } \\
\text { and SD) }\end{array}$ & \begin{tabular}{|l} 
Lap with FTS \\
decreased LOS \\
weighted mean \\
difference $(-1.65$ \\
days; $p<0.001)$ \\
\\
Lap with FTS \\
decreased time \\
to first bowel \\
movement $(-1.13$ \\
days; $p<0.001)$ \\
Lap with FTS \\
decreased total \\
postoperative \\
complication \\
rate (risk ratio \\
{$[$ RR], $0.65 ;$} \\
p $<0.001)$ \\
readmission rate \\
$(0.46 ; p<0.001)$ \\
\\
Lap with FTS \\
significantly \\
decreased \\
mortality $(0.45 ;$ \\
p $<0.001)$
\end{tabular} & $\begin{array}{l}\text { FTS showed LOS, } \\
\text { enhances recovery } \\
\text { and safety in } \\
\text { colorectal surgery }\end{array}$ \\
\hline
\end{tabular}




\begin{tabular}{|l||l|l|l|l|l|l|}
\hline \hline Citation & Quality Grade & Question & Search Strategy & $\begin{array}{c}\text { Inclusion/ } \\
\text { Exclusion } \\
\text { Criteria }\end{array}$ & $\begin{array}{l}\text { Outcomes/Data } \\
\text { Extraction/ } \\
\text { Analysis }\end{array}$ & $\begin{array}{c}\text { Key Findings } \\
\text { Recommendations/ } \\
\text { Implications }\end{array}$ \\
\hline & & & & $\begin{array}{l}\text { For median and } \\
\text { IQR median was } \\
\text { used and IQR } \\
\text { divided by } 1.35 \\
\text { for SD } \\
\text { Heterogeneity } \\
\text { determined using } \\
22 \text { or Cochran Q } \\
\text { test } \\
I^{2} \text { to quantify } \\
\text { heterogeneity, } \\
p<0.10 \text { and } \\
I^{2}>50 \% \\
\text { considered } \\
\text { substantial }\end{array}$ & \\
& & & & & \\
\hline
\end{tabular}

Legend: confidence intervals (CI), controlled clinical trials (CCTs), enhanced recovery program (ERP), enhanced recovery after surgery (ERAS), interquartile range (IQR), Jadad Composite Scale (JCS), mean difference (MD), minimally invasive gynecologic surgery (MIGS), Preferred Reporting Items for Systematic Reviews (PRISM), relative risk (RR), standard deviation (SD), standardized mean difference (SMD), verbal rating scale (VRS), weighted mean difference (WMD) 


\section{Appendix C}

\begin{tabular}{|c|c|c|}
\hline \multicolumn{3}{|r|}{$\begin{array}{l}\text { Pain Control Optimization Pathway (POP) } \\
\text { Care Process Overview for Providers }\end{array}$} \\
\hline POP Phase & Goal & \begin{tabular}{|l|} 
Considerations \\
\end{tabular} \\
\hline \multirow[t]{2}{*}{$\begin{array}{l}\text { Preoperative } \\
\text { Counseling }\end{array}$} & - $\quad$ Patient Selection & 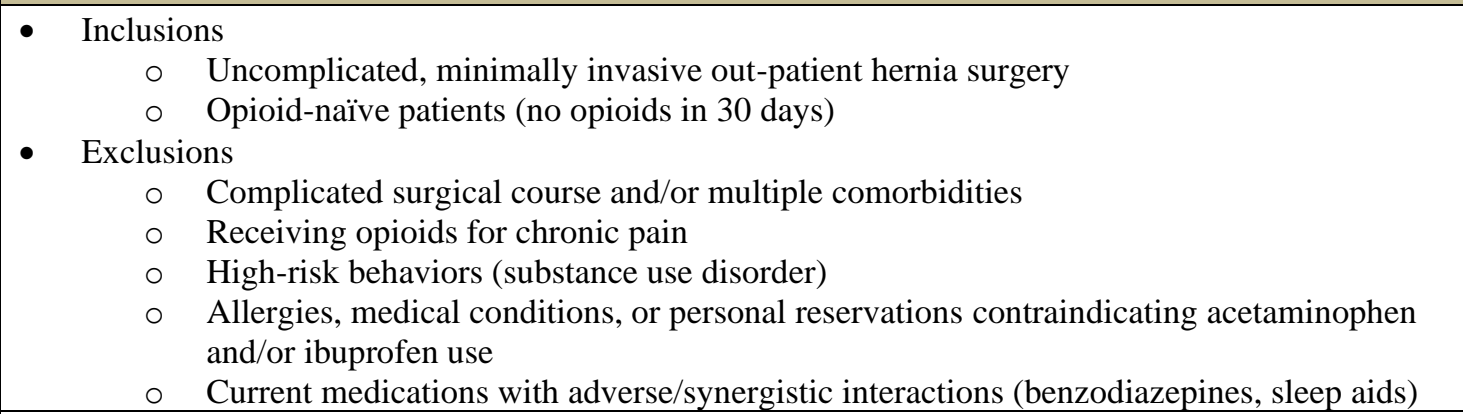 \\
\hline & $\begin{array}{l}\text { - } \begin{array}{l}\text { Actively engage patient as } \\
\text { participant in care }\end{array} \\
\text { - } \begin{array}{l}\text { Begin discharge planning } \\
\text { and counseling }\end{array}\end{array}$ & $\begin{array}{l}\text { - Set expectations \& norms } \\
\circ \quad \text { Pain is normal } \\
\circ \quad \text { You should be able to walk and do light activity } \\
\circ \quad \text { You may be sore } \\
\circ \quad \text { Pain will improve } \\
\circ \quad \text { Most patients for this procedure take under 8-10 pills } \\
\text { - Focus on function goals } \\
\circ \quad \text { After surgery it is important to eat, move, breathe deeply, and sleep } \\
\text { - Non-opioids for pain management (acetaminophen \& ibuprofen) } \\
\quad \text { Take acetaminophen and ibuprofen around the clock } \\
\circ \quad \text { Only take opioids for breakthrough pain } \\
\circ \quad \text { You will be given written information } \\
\text { - Managing pain without opioids } \\
\circ \quad \text { Utilize mindful breathing, ice, elevation, physical therapy (if prescribed), acupuncture } \\
\text { - Appropriate use of opioids } \\
\circ \quad \text { Prescribed opioids are for pain from surgery, not other conditions } \\
\text { - Adverse effects of opioids } \\
\circ \quad \text { Care should be taken with opioids, they have shown to be addictive, cause harm, and even } \\
\quad \text { overdose if used incorrectly or abused } \\
\quad \text { Adverse effects include nausea, vomiting, constipation, dependence, overdose, and } \\
\text { - diversion } \\
\text { Safe disposal \& storage of opioids }\end{array}$ \\
\hline
\end{tabular}




\begin{tabular}{|c|c|c|}
\hline & & $\begin{array}{l}\circ \begin{array}{l}\text { Disposing of unused opioids prevents others from accidentally overdosing. You may take to } \\
\text { approved collector (police), or mix with kitty litter and put in bag and throw in trash } \\
\text { You will be provided with website for local medication drop box }\end{array} \\
\text { - Discuss the Pain Control Optimization Pathway } \\
\circ \quad \begin{array}{l}\text { An opioid-sparing multimodal pain pathway means a combination of medications will be } \\
\text { administered by trained professionals }\end{array} \\
\circ \quad \text { Non-opioid treatments will be used first and opioids used as needed }\end{array}$ \\
\hline $\begin{array}{l}\text { Operative } \\
\text { Management }\end{array}$ & $\begin{array}{l}\text { Utilize an evidence-based } \\
\text { multimodal, opioid- } \\
\text { sparing technique for } \\
\text { first-line management } \\
\text { (unless contraindicated) } \\
\\
\text { - Adequately control } \\
\text { postoperative pain \& } \\
\text { decrease opioid } \\
\text { consumption }\end{array}$ & $\begin{array}{l}\text { - Anesthesia maintains standard intraoperative analgesia to ensure safety } \\
\circ \text { Preoperative: Acetaminophen 1 gram p.o. } \\
\circ \text { Intraoperative: local anesthetic (nerve block or infiltration) and ketorolac } 30 \mathrm{mg} \mathrm{IVP} \\
\circ \quad \text { Postoperative: ketorolac } 30 \mathrm{mg} \text { IVP prn (if not given in operation room) } \\
\text { - PACU RNs will maintain ASPAN standards, yet encourage sparing use of oral opioids and patient } \\
\text { education }\end{array}$ \\
\hline \multirow[t]{2}{*}{$\begin{array}{l}\text { Postoperative } \\
\text { Counseling }\end{array}$} & $\begin{array}{l}\text { Encourage and empower } \\
\text { patient to follow } \\
\text { discharge education }\end{array}$ & $\begin{array}{l}\text { - Reinforce with verbal and written communication functional pain management goals, normal pain } \\
\text { experiences, non-opioid adjuncts } \\
\text { - Instructions for scheduled acetaminophen and ibuprofen around the clock for } 72 \text { hours } \\
\quad \text { Acetaminophen } 650 \text { milligrams every six hours alternating with ibuprofen } 600 \text { milligrams } \\
\text { every six hours by mouth } \\
\text { - Education regarding efficiency of non-opioid pain management (elevating, splinting, ice or heat, } \\
\text { ambulation) } \\
\text { - Explicit instructions to only take opioids for breakthrough pain during first } 24-48 \text { hours } \\
\text { - Reiterate proper storage and disposal of opioids }\end{array}$ \\
\hline & $\begin{array}{l}\text { Utilize standardize, } \\
\text { procedure specific opioid } \\
\text { prescribing }\end{array}$ & $\begin{array}{l}\text { - Use the prescription drug monitoring program (PDMP) for controlled substances schedules 2-5 in } \\
\text { compliance with Michigan law } \\
\text { - } 0-10 \text { pills per provider preference }\end{array}$ \\
\hline
\end{tabular}

Note. Adapted from "Best Practices," by Michigan Opioid Prescribing Engagement Network, 2020 (https://michigan-open.org/). Copyright 2020 by The Regents of the University of Michigan. 


\section{Appendix D}

\section{Project Schedule}

\begin{tabular}{|c|c|c|c|c|c|c|c|c|c|c|c|c|c|c|c|c|c|c|c|c|c|c|c|c|}
\hline & & R780 & & & & & & & & $\mathrm{R} 780$ & & & & & & & & $\mathrm{R} 78$ & & & & & & \\
\hline 总 & $\begin{array}{l}\frac{7}{2} \\
\frac{\pi}{3}\end{array}$ & $\begin{array}{l}n \\
\frac{1}{2} \\
\frac{0}{3}\end{array}$ & $\begin{array}{l}n \\
\frac{y}{8} \\
3\end{array}$ & $\frac{5}{\frac{1}{2}}$ & $\begin{array}{l}\frac{a}{d} \\
\frac{0}{3}\end{array}$ & $\begin{array}{l}= \\
\frac{y}{0} \\
3\end{array}$ & $\frac{m}{\frac{m}{2}}$ & $\begin{array}{l}\frac{n}{2} \\
\frac{y}{2} \\
\frac{0}{3}\end{array}$ & $\begin{array}{l}\bar{y} \\
\frac{u}{0} \\
\sum^{2}\end{array}$ & $\begin{array}{l}m \\
\frac{u}{d} \\
\frac{u}{3}\end{array}$ & $\begin{array}{l}n \\
\frac{y}{0} \\
\frac{8}{3}\end{array}$ & $\begin{array}{l}\frac{1}{2} \\
\frac{0}{3} \\
3\end{array}$ & $\begin{array}{l}a \\
\frac{y}{0} \\
\frac{0}{3}\end{array}$ & $\begin{array}{l}= \\
\frac{y}{0} \\
\frac{0}{3}\end{array}$ & $\frac{n}{y}$ & $\begin{array}{l}\frac{n}{y} \\
\frac{y}{d} \\
\frac{0}{3}\end{array}$ & $\frac{\bar{y}}{3}$ & $\begin{array}{l}m \\
\frac{u}{0} \\
0 \\
3\end{array}$ & $\begin{array}{l}n \\
\frac{y}{0} \\
\frac{d}{3}\end{array}$ & $\frac{\bar{y}}{3}$ & $\begin{array}{l}a \\
\frac{u}{0} \\
0 \\
z\end{array}$ & $\begin{array}{l}= \\
\frac{\pi}{2} \\
\frac{0}{3}\end{array}$ & $\frac{n}{\frac{y}{8}}$ & $\begin{array}{l}\frac{n}{y} \\
\frac{y}{d} \\
\frac{0}{3}\end{array}$ \\
\hline $\begin{array}{l}\text { Meet with } \\
\text { preceptor }\end{array}$ & $\mathrm{X}$ & $\mathrm{X}$ & $X$ & $\mathrm{X}$ & $\mathrm{X}$ & $X$ & $X$ & $\mathrm{X}$ & $X$ & $X$ & $X$ & $\mathrm{X}$ & $X$ & $\mathrm{X}$ & $X$ & $\mathrm{X}$ & $\mathrm{X}$ & $\mathrm{X}$ & $X$ & $X$ & $X$ & $\mathrm{X}$ & $X$ & $\mathrm{X}$ \\
\hline $\begin{array}{l}\text { Collaborat } \\
\text { e with key } \\
\text { stakeholde } \\
\text { rs }\end{array}$ & & $\mathrm{X}$ & & $\mathrm{X}$ & & & $X$ & & $X$ & & X & & $\mathrm{X}$ & & $\mathrm{X}$ & & $\mathrm{X}$ & & $\mathrm{X}$ & & $\mathrm{X}$ & & $\mathrm{X}$ & \\
\hline $\begin{array}{l}\text { Prepare } \\
\text { project } \\
\text { proposal } \\
\text { and plan } \\
\text { interventi } \\
\text { on } \\
\end{array}$ & $X$ & $\mathrm{X}$ & $X$ & $\mathrm{X}$ & $\mathrm{X}$ & $X$ & X & $X$ & & & & & & & & & & & & & & & & \\
\hline $\begin{array}{l}\text { Collaborat } \\
\text { e with } \\
\text { interprofe } \\
\text { ssional } \\
\text { leadership } \\
\text { team }\end{array}$ & & & & & & & & $\mathrm{X}$ & & & $\mathrm{X}$ & & $\mathrm{X}$ & & $\mathrm{X}$ & & $\mathrm{X}$ & $X$ & $\mathrm{X}$ & $X$ & $\mathrm{X}$ & $\mathrm{X}$ & $X$ & $X$ \\
\hline $\begin{array}{l}\text { Create a } \\
\text { mission } \\
\text { and vision }\end{array}$ & & & & & & & & $X$ & & & & & & & & & & & & & & & & \\
\hline $\begin{array}{l}\text { Prepare } \\
\text { IRB and } \\
\text { ERPC } \\
\text { proposal }\end{array}$ & & & & & & & & $\mathrm{X}$ & $\mathrm{X}$ & $\mathrm{X}$ & $\mathrm{X}$ & & & & & & & & & & & & & \\
\hline $\begin{array}{l}\text { Communi } \\
\text { cate }\end{array}$ & & & & & & & & & $\mathrm{X}$ & & $X$ & & $\mathrm{X}$ & & $\mathrm{X}$ & & & & & & & & & \\
\hline
\end{tabular}




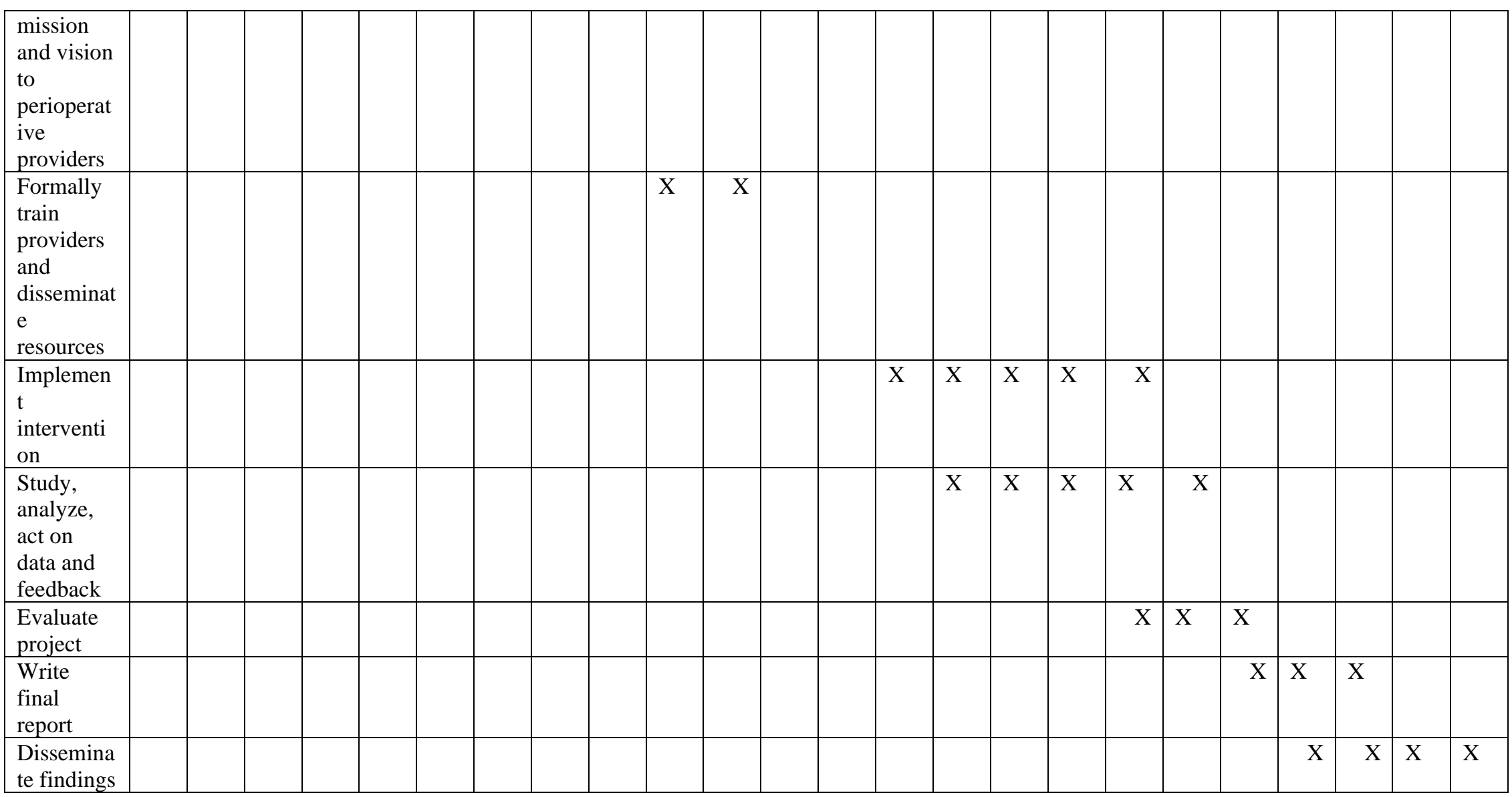


Appendix E

Data Collection Tool for Outcome Measure and Population Variable Evaluation

\begin{tabular}{|c|c|c|c|c|c|c|c|c|c|c|c|}
\hline$A$ & B & c & D & E & $\mathrm{F}$ & $G$ & H & 1 & 1 & $\mathrm{k}$ & $L$ \\
\hline Unique Identifier & Gender & Age & Race & ASA_Classification & BMI & $\begin{array}{l}\text { Mean_Painscore_Discharge } \\
\text { (pain on a 10-point NAS at } \\
\text { discharge from PACU) }\end{array}$ & $\begin{array}{l}\text { Mean_Painscore_-72hr (pain } \\
\text { on a 10-point NRs 72-hours } \\
\text { postoperatively) }\end{array}$ & $\begin{array}{l}\text { Where you prescribed a standard } \\
\text { procedure-specific opioid } \\
\text { prescripition? (yes or no) }\end{array}$ & $\begin{array}{l}\text { Did you consume your } \\
\text { entire prescription? (yes } \\
\text { or no) }\end{array}$ & $\begin{array}{l}\text { Did you properly dispose of } \\
\text { extra opioid pills? (yes or } \\
\text { no) }\end{array}$ & $\begin{array}{l}\text { Overall, were you satisfied with your acute } \\
\text { postoperative pain management technique? (Yes } \\
\text { or no) }\end{array}$ \\
\hline$\frac{2}{3}$ & & & & & & & & & & & \\
\hline & & & & & & & & & & & \\
\hline 5 & & & & & & & & & & & \\
\hline
\end{tabular}




\section{Appendix F}

\section{Data Collection Tool for Process Measures}

\begin{tabular}{|c|c|c|c|c|c|c|c|}
\hline \multirow[t]{2}{*}{ Measure } & \multirow[t]{2}{*}{ Operational Definition } & \multicolumn{2}{|c|}{ Numerator (Mean) } & \multicolumn{2}{|c|}{ Denominator (Mean) } & \multicolumn{2}{|c|}{ Percentage (Mean) } \\
\hline & & 30 days & 60 days & 30 days & 60 days & 30 days & 60 days \\
\hline $\begin{array}{l}\text { Perioperative provider } \\
\text { compliance with utilizing an } \\
\text { opioid-sparing, multimodal } \\
\text { technique as first-line } \\
\text { treatment for acute pain }\end{array}$ & $\begin{array}{l}\text { The numerator is the } \\
\text { number of opioid-naïve } \\
\text { adult patients undergoing } \\
\text { minimally invasive hernia } \\
\text { surgery who received an } \\
\text { opioid-sparing, multimodal } \\
\text { technique and the } \\
\text { denominator is the total } \\
\text { number of opioid-naïve } \\
\text { adult patients undergoing } \\
\text { minimally invasive hernia } \\
\text { surgery within the same } \\
\text { period of time. Data } \\
\text { obtained by the project } \\
\text { manager or leadership team } \\
\text { member from EHR. }\end{array}$ & & & & & & \\
\hline $\begin{array}{l}\text { Perioperative provider } \\
\text { compliance with preoperative } \\
\text { patient counseling }\end{array}$ & $\begin{array}{l}\text { The numerator is the } \\
\text { number of opioid-naïve } \\
\text { adult patients undergoing } \\
\text { minimally invasive hernia } \\
\text { surgery receiving } \\
\text { preoperative counseling on } \\
\text { the use of an opioid-sparing } \\
\text { multimodal acute } \\
\text { postoperative pain } \\
\text { management technique and } \\
\text { standardize opioid }\end{array}$ & & & & & & \\
\hline
\end{tabular}




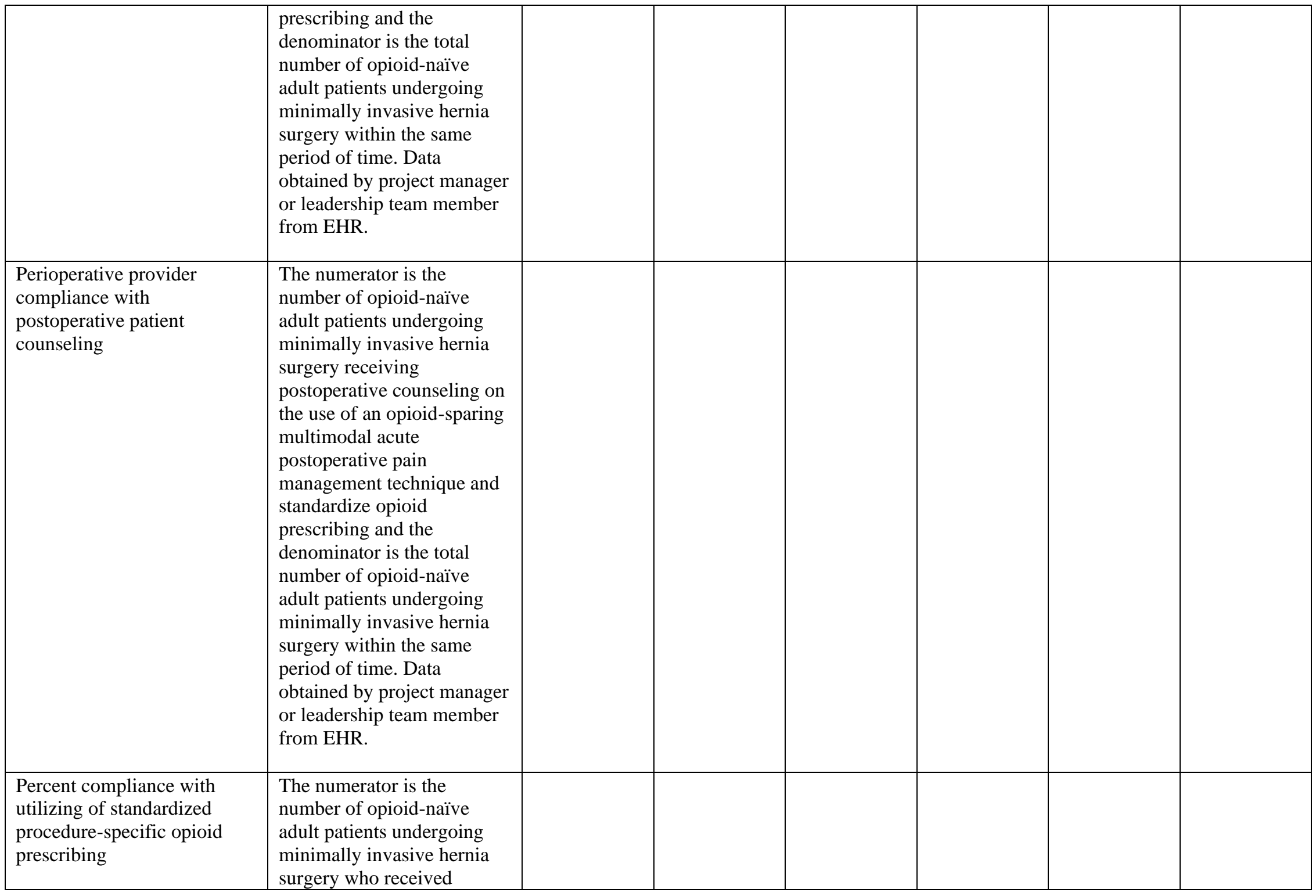




\begin{tabular}{|l|l|l|l|l|l|}
\hline & $\begin{array}{l}\text { standardized procedure- } \\
\text { specific opioid prescribing } \\
\text { and the denominator is the } \\
\text { total number of opioid-naïve } \\
\text { adult patients undergoing } \\
\text { minimally invasive hernia } \\
\text { surgery within the same } \\
\text { period of time. Data } \\
\text { obtained by the project } \\
\text { manager or leadership team } \\
\text { member from EHR. }\end{array}$ & & & & \\
\hline
\end{tabular}

